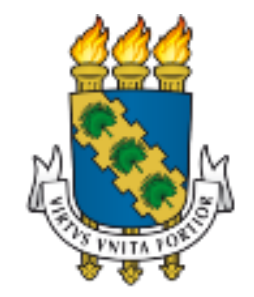

UNIVERSIDADE FEDERAL DO CEARÁ

CENTRO DE TECNOLOGIA

DEPARTAMENTO DE ENGENHARIA DE TRANSPORTES

PROGRAMA DE PÓS-GRADUAÇÃO EM ENGENHARIA DE TRANSPORTES

MARIA REGILENE GONÇALVES DE ALCANTARA

ESTUDO DA UTILIZAÇÃO DE CINZAS PESADAS DE TERMOELÉTRICAS PARA PRODUÇÃO DE BLOCOS DE CONCRETO PARA PAVIMENTOS INTERTRAVADOS

FORTALEZA 
MARIA REGILENE GONÇALVES DE ALCANTARA

ESTUDO DA UTILIZAÇÃO DE CINZAS PESADAS DE TERMOELÉTRICAS PARA PRODUÇÃO DE BLOCOS DE CONCRETO PARA PAVIMENTOS INTERTRAVADO

Dissertação apresentada ao Programa de Pós-Graduação em Engenharia de Transportes da Universidade Federal do Ceará, como requisito parcial para obtenção do título de Mestre em Engenharia de Transportes. Área de concentração: Infraestrutura de Transporte.

Orientadora: Profa. Dra. Suelly Helena de Araújo Barroso.

FORTALEZA 
Dados Internacionais de Catalogação na Publicação

Universidade Federal do Ceará

Biblioteca Universitária

Gerada automaticamente pelo módulo Catalog, mediante os dados fornecidos pelo(a) autor(a)

A319e Alcantara, Maria Regilene Gonçalves de.

Estudo da utilização de cinzas pesadas de termoelétricas para produção de blocos de concreto para pavimentos intertravados / Maria Regilene Gonçalves de Alcantara. - 2018.

99 f. : il. color.

Dissertação (mestrado) - Universidade Federal do Ceará, Centro de Tecnologia, Programa de PósGraduação em Engenharia de Transportes, Fortaleza, 2018.

Orientação: Prof. Dr. Suelly Helena de Araújo Barroso.

1. Pavimento intertravado. 2. Resíduos. 3. Termoelétrica. 4. Cinzas pesadas.. I. Título.

CDD 388 


\section{ESTUDO DA UTILIZAÇÃO DE CINZAS PESADAS DE TERMOELÉTRICAS PARA PRODUÇÃO DE BLOCOS DE CONCRETO PARA PAVIMENTOS INTERTRAVADO}

Dissertação apresentada ao Programa de PósGraduação em Engenharia de Transportes da Universidade Federal do Ceará, como requisito parcial à obtenção do título de mestre em Engenharia de Transportes. Área de concentração: Infraestrutura de Transporte.

Aprovada em: 30/ novembro / 2018.

BANCA EXAMINADORA

Profa. Dra. Suelly Helena de Araújo Barroso (Orientadora)

Universidade Federal do Ceará (UFC)

Prof. PhD. Jorge Barbosa Soares (Examinador Interno)

Universidade Federal do Ceará (UFC)

Prof. Dr. Antonio Eduardo Bezerra Cabral (Examinador Externo)

Universidade Federal do Ceará (UFC) 
A Deus.

Ao meu adorado filho Mezekiell

Á minha amada Família pelo amor incondicional. 


\section{AGRADECIMENTOS}

A Deus, em primeiro lugar, pois foi pela fé e confiança nele que pude concluir essa etapa da minha vida. E por ele me dar forças e está sempre presente na minha vida, principalmente nesta caminhada que foi o Mestrado.

A meus pais, Agustinho e Francisca, por serem meus alicerces e exemplo, por todo amor e dedicação que sempre me deram, por todos os momentos que estiveram ao meu lado, me apoiando incondicionalmente e não me deixando desistir.

Ao meu adorado e amado filho Mezekiell, por toda a paciência, amor, carinho, dedicação e compreensão, por entender a minha "ausência" por conta do Mestrado, Te Amo, mas que tudo.

As minhas irmãs, Regilane, Regiane e Regienne pelo amor incondicional, sem medidas, sem noção, sem cobrança, pela dedicação, carinho e atenção, por estarem sempre comigo em todos os momentos da minha vida.

Ao meu cunhado José Pereira (bimba) e minha avó materna Euclides (carmosa), in memory, agradeço pelo incentivo durante toda a vida.

A minha orientadora, Professora Dra. Suelly Barroso, pela orientação, ensinamentos, paciência e incentivo, que foram de fundamental importância para elaboração e conclusão deste trabalho.

Agradeço aos professores Jorge Barbosa Soares e Antonio Eduardo Bezerra Cabral, que gentilmente aceitaram o convite para participarem da banca avaliadora. Muito grata pela disponibilidade, colaboração e conhecimentos compartilhados.

Um agradecimento muito especial, a Lilian Brasileiro, por ter sido um anjo enviado por Deus em todas as horas que pensei em desistir, sem seu companheirismo e parceria teria sido mais difícil esta caminhada, que Deus lhe abençoe sempre amiga.

Agradeço a Raimi e Sarah por todas as conversas, incentivo e a amizade construída durante o mestrado, e por toda a vida.

Um agradecimento muito especial, Ana Tália, Daianne, Marcia e Lurdinha pelo apoio nos dias difíceis, pela amizade, pelo abrigo, por me fazer sentir parte de suas famílias quando eu estava longe da minha.

A Annie e Wesley, pelo ombro amigo, pelo café no terceiro expediente, pelo afago nas horas ruins, por cinco minutos apenas do seu tempo para me ajudar, por sempre torcer que tudo iria dar certo, pela compressão e pela amizade. 
Ao Zacarias e Clelia, por toda colaboração e amizade desde que cheguei no departamento.

Agradecimento especial ao Ricardo, Romulo, Helano, Mauricio, Anselmo e Manoel, por todo o apoio e ajuda na parte mais pesada do trabalho, por todo o empenho na execução dos ensaios, pois com colaboração de você, conseguimos, muito obrigado.

Aos meus colegas alunos do programa, em especial a Jorge Lucas, Jorge Luís, Lucas Cavalcante, Sameque e Manoel Gualberto, agradeço por todos os momentos juntos.

A Daniele Ibiabina, por todas as conversas, conselhos, grupo de autoajuda e amizade, compartilhada nesta caminhada.

Ao Bruno Tiago, pela amizade, colaboração e orientação, principalmente nos momentos mais cruciais.

Aos médicos Jacob, Eleinaide, Illania e Denise, que cuidaram da minha saúde, não apenas com remédios, mas com incentivos e profissionalismo nas horas mais difíceis, que juntos me ajudaram chegar até aqui, muito obrigado por acompanharem minha recuperação.

A todos os professores, técnicos e colaboradores do Departamento de Engenharia de Transporte (DET) - UFC pelos conhecimentos transmitidos.

Agradeço também ao coordenador, aos pesquisadores, professores e alunos, das outras linhas de pesquisa do projeto, por compartilhar informações que colaboraram com o estudo. Em especial aos alunos Arlego, Alexandre e Lilian, obrigada pela colaboração quando solicitados.

A coordenação do Programa de Pós-Graduação em Engenharia de Transportes (PETRAN), representada pela Professora Veronica Castelo Branco, muito obrigada pelo apoio, colaboração e incentivo, quando precisei.

A Usina Termoelétrica Pecém, pela disponibilidade dos materiais, colaboração e incentivo, pelo acesso às informações, e por todo o apoio financeiro para realização desse estudo.

As Empresas OCS mineração e cimento Apodi, pela disponibilidade do material necessário para que o estudo fosse realizado.

Aos Coordenadores dos Laboratórios: Laboratório de Mecânica dos Pavimentos (CT-Asfalto), Laboratório de Materiais de Construção Civil (DEECC), Laboratório de Física, Laboratório de Saneamento Ambiental da UFC e ao NUTEC por permitir que utilizasse a sua infraestrutura física e pessoal para realização dos ensaios laboratoriais

Ao IFCE - Campus Juazeiro do Norte, por disponibilizar equipamentos e laboratórios para colaboração do estudo. Por permitir o afastamento da Autora para capacitação, 
em especial aos meus colegas de trabalho e amigos os Professores e Técnicos, Antonio Júnior, Wilson Brito, Vidal Figueiredo, Alex Juscileno, Antonio Ademar, Carlos Regis, Rosimeire Brito, Barroso Lima, Ligia, Fabrícia, Elaine, Maria do Carmo, Marcos Antonio, Derig, Romulo, Régia, Cieusa, Nárcelio, Victor, Amaral, Lindomar, José Carlos e Atila, por todo o apoio durante essa caminhada.

As minhas amigas-irmãs Viviane Viana e Claudia Silva, por todos os momentos compartilhados e por fazerem parte da minha família, obrigada por todas as conversas de incentivos e puxões para realidade.

A professora Terezinha de Jesus, que foi minha primeira orientadora acadêmica (graduação), por ter se tornado uma amiga, por não me deixar desistir quando era o mais fácil e logico a se fazer, por me acompanhar na fase tão delicada deste Mestrado, e por ser essa pessoa humana e solidaria sempre, muito obrigada por estado comigo nesta caminhada.

A todos que diretamente ou indiretamente colaboram de alguma forma com este trabalho, que eu tenha esquecido, o meu mais sinceros muito obrigada. 
“O Amor não é invejoso, não trata com leviandade, não se ensoberbece, não se porta com indecência, não busca os seus interesses, não se irrita, não suspeita mal, não folga com a injustiça, mas folga com a verdade. Tudo sofre, tudo crê, tudo espera e tudo suporta. O Amor nunca falha." (Primeira Epístola aos Coríntios - Cap.13) 


\section{RESUMO}

Os setores da construção civil e pavimentação possuem grande potencial para absorver resíduos que podem ser usados na fabricação de Blocos de Concreto para Pavimentos Intertravados (BCPI). Baseado nessa alternativa, o estudo teve por objetivo testar as cinzas pesadas (bottom $a s h$, oriundas de uma usina termoelétrica do estado do Ceará, na substituição de agregados miúdos naturais para fabricação de BCPI. Para tanto, foram coletadas cinzas da termoelétrica e agregados convencionais. Inicialmente, foram realizados ensaios de caracterização dos materiais, dosagem e fabricação do concreto, bem como ensaios mecânicos e ambientais dos blocos de acordo com especificações normativas. Fabricou-se o concreto para os blocos com Traço de Referência (TR) e Traços (T) alternativos nas porcentagens de T10, T20, T30, T40 e T50 de substituição em sua fração miúda por cinza. Foram realizados ensaios no concreto no estado fresco, em todos os traços, pelo método de ensaio consistômetro "VeBe" onde foram classificados como concreto extremamente seco. Todos os blocos foram aprovados quanto à inspeção visual, avaliação dimensional e desgaste à abrasão. Entretanto, para o caso do ensaio de resistência à compressão, constatou-se que todos os traços, inclusive o TR, apresentaram valores inferiores ao recomendado na ABNT NBR 9781:2013 é de 35 Mpa. Ambientalmente, a cinza pesada e os blocos classificaram-se como resíduos não perigosos e não inertes. Concluise que os traços utilizados na fabricação dos BCPI com cinza pesada e agregados naturais, segundo avaliação da norma, não podem ser utilizados para tráfego de veículos leves e veículos comerciais de linha, mas podem ser empregados em ambientes com sobrecargas pequenas, como, por exemplo, em calçadas, praças e ciclovias. Sugere-se que a norma brasileira referente aos BCPI sejam revistas, para que possam considerar uma análise mais mecanística dos esforços que atuam no pavimento intertravado.

Palavras-chave: Pavimento intertravado. Resíduos. Termoelétrica. Cinzas pesadas. 


\begin{abstract}
The construction and paving sectors have great potential to absorb wastes that can be used in the manufacture of Concrete Blocks for Interlocking Pavements (CBIP), making it an important engineering solution. Based on this alternative, the study had as objective to test the bottom ash, from a thermoelectric of the state of Ceará, in the substitution of natural fine aggregates in the manufacture of CBIP. In order to do so, it was collected ashes of the thermoelectric and conventional aggregates for the measurement of a reference trace and alternative traces of substitution. Initially, tests were carried out to characterize the materials, dosage and manufacturing of the concrete, as well as mechanical and environmental tests of the blocks according to normative specifications. The concrete for the blocks with wix of Reference (TR) and Traces (T) in the percentages of T10, T20, T30, T40 and T50 of substitution in its small fraction by ash was fabricated. Tests were performed on the concrete in the fresh state, of all traces, by the "VeBe" consistometer test method being classified as "extremely dry" concrete. All block were approved for visual inspection, dimensional assessment and abrasion wear. However, in the case of the compressive strength test, it was found that all traces, including TR, presented values lower than $35 \mathrm{Mpa}$ at 28 days of cure. Environmentally bottom ash and blocks were classified as non-hazardous and non-inert waste. It is concluded that the traces used in the manufacture of CBIP with bottom ash and natural aggregates, according to the evaluation of ABNT NBR 9781: 2013, can not be used for traffic of light vehicles and commercial vehicles of line, but can be used in environments with overloads such as sidewalks, squares and cycle paths.
\end{abstract}

Keywords: Interlocked pavement. Waste. Thermoelectric. Bottom ashes. 


\section{LISTA DE FIGURAS}

Figura 1 - Estrada antiga, Via Ápia, construída com características de intertravamento ........ 22

Figura 2 - Primeira forma, planta e perfil de blocos ..........................................................24

Figura 3 - Exemplos de peças de concreto dos tipos I, II, III e IV ...................................... 26

Figura 4 - Exemplos de formas utilizadas no processo dormido ............................................ 34

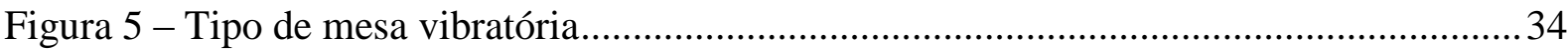

Figura 6 - Máquina para blocos do tipo vibro-prensa hidráulica.......................................... 35

Figura 7 - Seção transversal típica das camadas do pavimento intertravado........................... 37

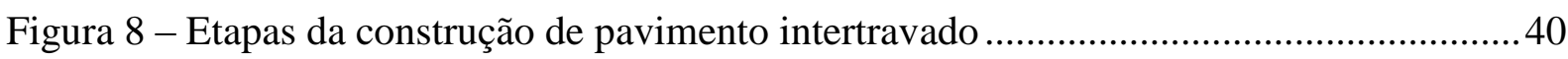

Figura 9 - Exemplos de aplicação de pavimentos intertravados ............................................ 42

Figura 10 - Normas para classificação e padronização dos resíduos sólidos. ......................... 44

Figura 11 - Visão geral da Usina Termelétrica Pecém ........................................................... 45

Figura 12 - Aspectos da cinza leve (à esquerda) e cinza pesada (à direita) ............................ 47

Figura 13 - Localização da pedreira em relação ao Campus do PICI....................................... 49

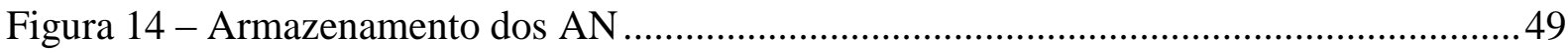

Figura 15 - Localização da UTP em relação ao Campus do PICI ...........................................50

Figura 16 - Transporte e disposição da cinza pesada no pátio do estacionamento da UFC ....50

Figura 17 - Quarteametno e destinação adequada da cinza. .................................................51

Figura 18 - Fluxograma resumido das etapas metodológicas...............................................52

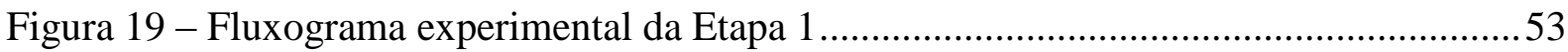

Figura 20 - Adaptação do ensaio de massa específica para o caso da cinza pesada.................54

Figura 21 - Aggregate Image Measurement System (AIMS)...............................................55

Figura 22 - Máquina de Vibroprensa Tprex. .....................................................................59

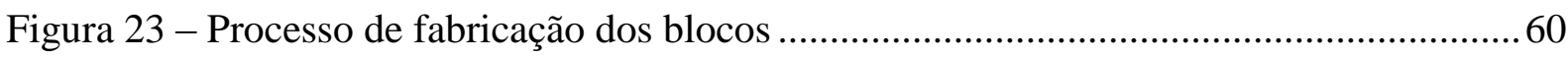

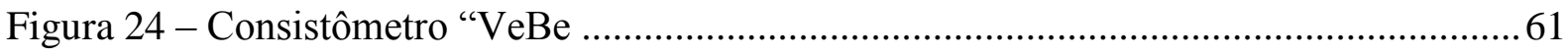

Figura 25 - Equipamento utilizado para o ensaio de Abrasão por desgaste ............................63

Figura 26 - Resultado da distribuição granulométrica de todos os materiais da pesquisa........64

Figura 27 - Resultado da comparação com os limites para agregados graúdos (natural e CPIN)

Figura 28 - Resultado da comparação com os limites para agregados miúdo (natural e CPIN) 66

Figura 29 - Resultada da comparação com os limites areia natural 66 
Figura 30 - Resultado das curvas granulométricas dos AMN e AMCP após o fracionamento 67

Figura 31 - Imagens de forma geradas pelo AIMS por peneira (cinza pesada).....................69

Figura 32 - Imagens de superfície geradas pelo AIMS..................................................... 70

Figura 33 - Procedimentos de Ensaio do consistômetro "VeBe" modificado ..........................73

Figura 34 - Resultados do ensaio de inspeção visual............................................................. 75

Figura 35 - Resultado ensaio de avaliação dimensional ..................................................... 75

Figura 36 - Exemplo do ensaio de resistência a compressão............................................... 78

Figura 37 - Resultado do ensaio de resistência à compressão dos BCPI................................ 80

Figura 38 - Resultado do ensaio de desgaste à abrasão para CP1 e CP2 de cada traço............ 82 


\section{LISTA DE TABELAS}

Tabela 1 - Formatos dos Blocos Fabricados no Mundo nas Últimas Décadas ........................225

Tabela 2 - Peças de Concreto para Pavimentação Normatizadas ........................................... 26

Tabela 3 - Pigmentos Inorgânicos para Colorir as Peças de Concreto ......................................30

Tabela 4 - Resistência Característica à Compressão dos BCPI ................................................33

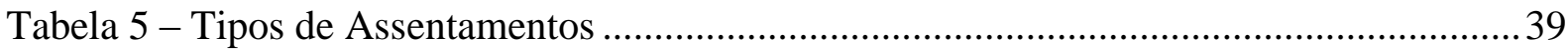

Tabela 6 - Movimentos de Deslocamentos Individuais das Peças ........................................ 41

Tabela 7 - Nomenclatura Usada para Identificar os Materiais Usados na Pesquisa ................48

Tabela 8 - Classificação das Propriedades de Forma dos Agregados Através do Uso do AIMS

Tabela 9 - Dados da Caracterização do Cimento ......................................................................56

Tabela 10 - Consumo de Materiais em kg de Concreto no TR $\left(\right.$ para $\left.1 \mathrm{~m}^{3}\right)$.............................57

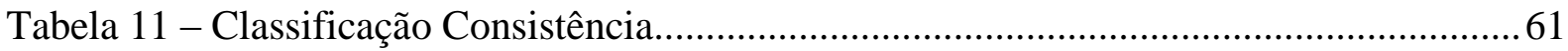

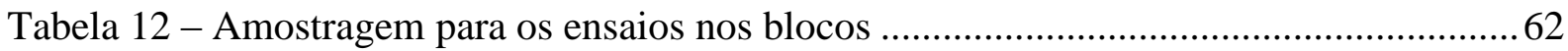

Tabela 13 - Separação das CPIN, Conforme a Distribuição Granulométrica.......................... 65

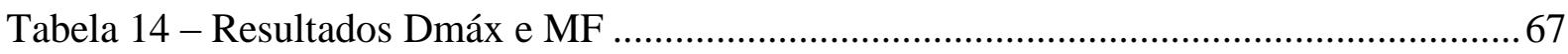

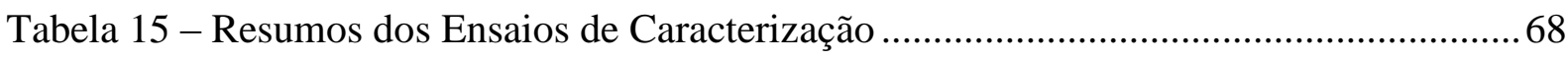

Tabela 16 - Resumo dos Resultados Obtidos na Análise do AIMS ........................................69

Tabela 17 - Extrato Lixiviado e Solubilizado da Cinza Pesada ............................................... 71

Tabela 18 - Resultados em Peso da Substituição da AMCP para $1 \mathrm{~m}^{3}$ de Concreto ............... 72

Tabela 19 - Resultados do Consistômetro "VeBe" Modificado para os Seis Traços Investigados

Tabela 20 - Resultados dos Ensaios de Absorção de Água .................................................... 76

Tabela 21 - Dados Estatísticos da Resistência à Compressão dos BCPI aos 7 dias ................ 79

Tabela 22 - Dados Estatísticos da Resistência à Compressão dos BCPI aos 28 dias .............. 79

Tabela 23 - Resistencia Média e Resistência Característica ................................................... 80 


\section{LISTA DE ABREVIATURAS E SIGLAS}

ABCP Associação Brasileira de Cimento Portland

ABNT Associação Brasileira de Normas Técnicas

ACI Institute of American Concrete

AGCP Agregado Graúdo Cinza Pesada

AGN Agregado Graúdo Natural

AIMS Aggregate Image Measurement System

AMCP Agregado Miúdo Cinza Pesada

AMN Agregado Miúdo Natural

AN Agregado Natural

ARN Areia Natural

BCPI Blocos de Concreto para Pavimentos Intertravados

CBR California Bearing Ratio

CIPP Complexo Industrial e Portuário do Pecém

CONAMA Conselho Nacional do Meio Ambiente

CPIN Cinza Pesada In Natura

DAS Spray Dryer Ash

DEECC Departamento de Engenharia Estrutural e Construção Civil

Dmáx Diâmetro Máximo Característico

DNIT Departamento Nacional de Infraestrutura de Transportes

DRX Difração de Raio-X

EPUSP Escola Politécnica da Universidade de São Paulo

FGD Dessulfurização dos Gases da Combustão

FRX Fluorescência de Raios-X

IBGE Instituto Brasileiro de Geografia e Estatística

IBRACON Instituto Brasileiro de Concreto

IFCE Instituto Federal de Educação, Ciência e Tecnologia do Ceará

IPEA Instituto de Pesquisa Econômica Aplicada

IPT Instituto de Pesquisas Tecnológicas

ISC Índice de Suporte Califórnia

ITERS Instituto Tecnológico do Estado do Rio Grande do Sul

LMP Laboratório de Mecânica dos Pavimentos 
LMCC Laboratório de Materiais da Construção Civil

NBR Norma Regulamentadora Brasileira

NUTEC Núcleo de Tecnologia Industrial do Ceará

PNRS Política Nacional de Resíduos Sólidos

RMF Região Metropolitana de Fortaleza

TR Traço de Referência

T10 Traço com $10 \%$ de substituição de cinza pesada

T20 Traço com $20 \%$ de substituição de cinza pesada

T30 Traço com $30 \%$ de substituição de cinza pesada

T40 Traço com $40 \%$ de substituição de cinza pesada

T50 Traço com $50 \%$ de substituição de cinza pesada

UFC Universidade Federal do Ceará

UG Unidade Geradora

UTP Usina Termoelétrica Pecém

VMP Valores Máximo Permitido 


\section{SUMÁRIO}

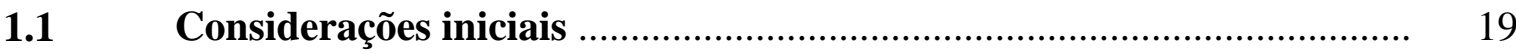

$1.2 \quad$ Justificativa e problema de pesquisa …............................................... 20

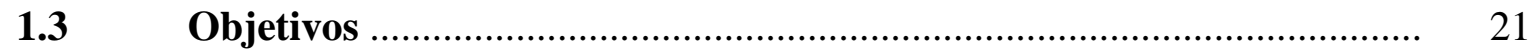

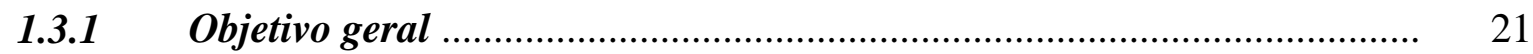

1.3.2 Objetivos específicos ........................................................................... 21

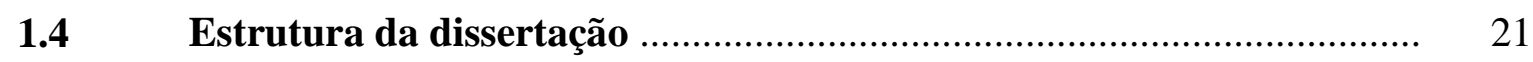

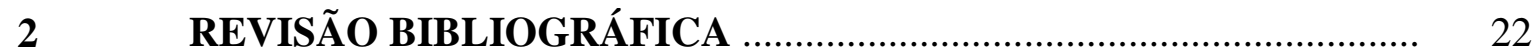

2.1 Histórico e principais conceitos sobre pavimentos intertravado ......... 22

$2.2 \quad$ Formato, tipologia e forma dos BCPI ……........................................ 23

2.3 Materiais empregados na fabricação dos BPCI …................................ 27

2.3.1 Cimento Portland .................................................................................. 27

2.3.2 Agregados Graúdos ........................................................................... 28

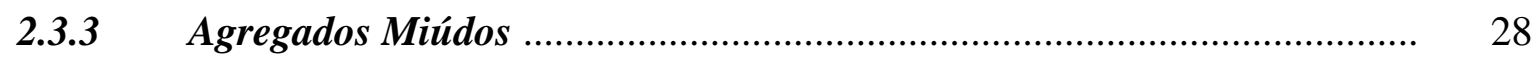

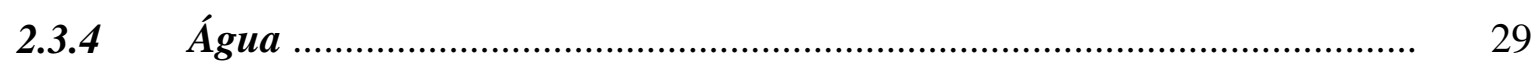

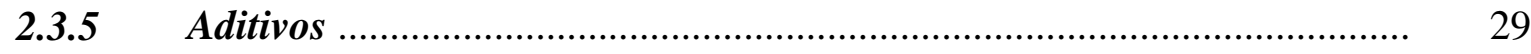

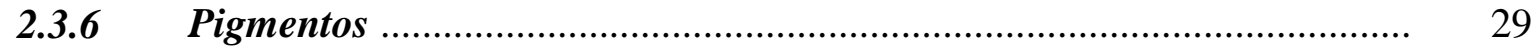

$2.4 \quad$ Dosagem do concreto …................................................................. 30

2.4.1 Concreto utilizado na fabricação dos BCPI (Concreto Seco) ................... 30

2.5 Recomendações no processo de produção e aprovação dos BCPI ....... 32

2.6 Estrutura do Pavimento Intertravado .................................................. 36

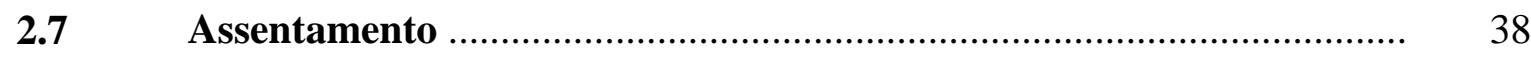

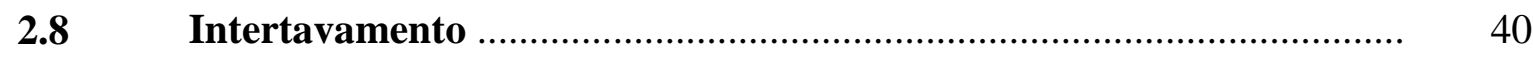

2.9 Aplicações ................................................................................. 41

2.10 Algumas Vantagens e Desvantagens ............................................... 42

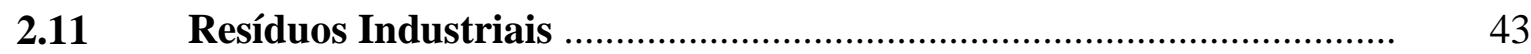

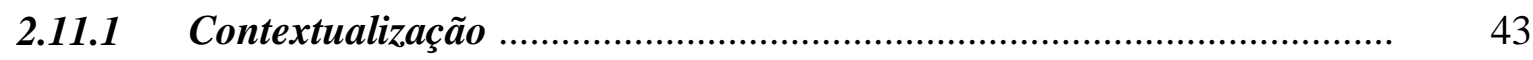

2.11.2 Legislação Ambiental (definição e conceitos) ......................................... 43

2.11.3 Resíduos da Usina Termoelétrica Pecém (UTP) .................................... 45

2.12 Considerações Finais ..................................................................... 47

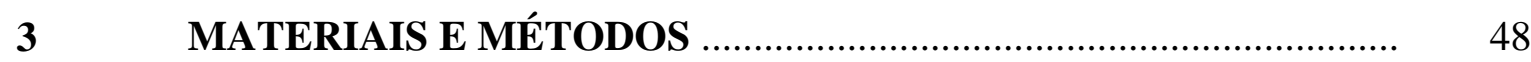

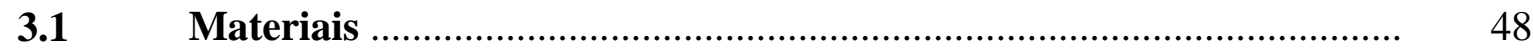




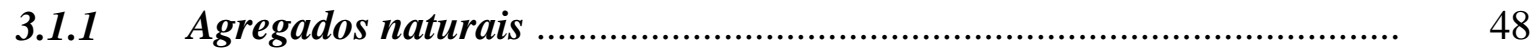

3.1.2 Cinza Pesada ou Bottom Ash ............................................................... 49

3.1.3 Aglomerante (cimento Porthand) ....................................................... 51

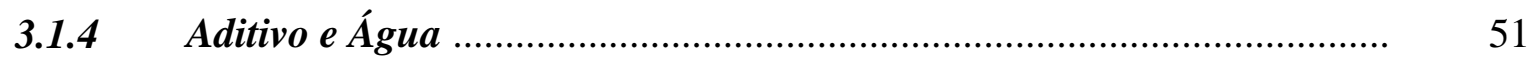

3.2 O Programa Experimental .......................................................... 52

3.2.1 Etapa 1 - Ensaios de caracterização dos materiais ............................... $\quad 52$

3.2.2 Etapa 2-Escolha dos Traços ............................................................ 57

3.2.3 Etapa 3 - Fabricação dos Blocos e realização dos Ensaios Normatizados ............................................................................... 59

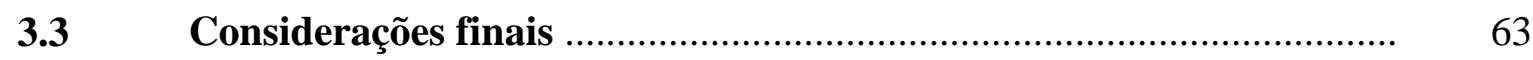

4 ANÁLISE E DISCUSSÃO DOS RESULTADOS ............................... 64

4.1 Resultados dos Ensaios de Caracterização dos Materiais .................... 64

4.2 Resultados da Escolha dos Traços …................................................ 71

4.3 Resultados da Fabricação dos Blocos e da Realização dos Ensaios

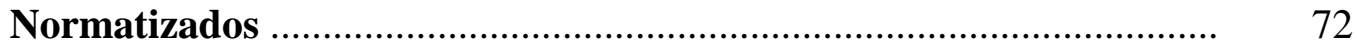

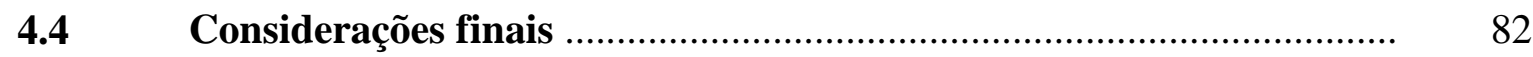

5 CONSIDERAÇÕES E RECOMENDAÇÕES .................................. 83

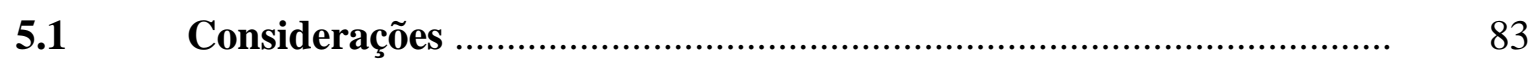

5.2 Quanto aos Resultados dos Ensaios de Caracterização dos Materiais 83

5.3 Quanto aos Resultados dos Ensaios Mecânicos nos Blocos

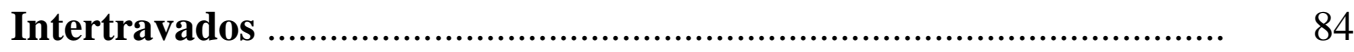

$5.4 \quad$ Sugestões para novas Pesquisas ......................................................... 85

5.5 Considerações finais ........................................................................ 85

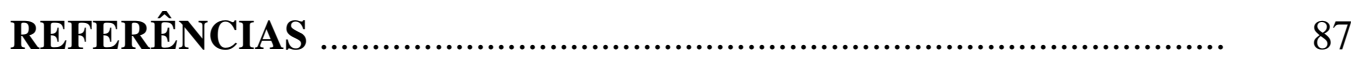

APÊNDICE A - PROCESSO DE FABRICAÇÃO DO CONCRETO

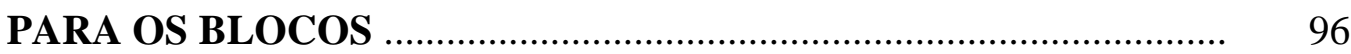




\section{INTRODUÇÃo}

\subsection{Considerações iniciais}

A questão meio ambiente, sociedade e sustentabilidade tem sido motivo de intensos debates no âmbito técnico e acadêmico, compondo um novo paradigma no intuito de evitar ou amenizar as consequências do uso inadequado dos recursos naturais haja vista que esses são limitados, sendo importante encontrar alternativas para garantir o progresso sem que se esgotem. De acordo com Costa (1998), o aproveitamento de resíduos deve ser encarado como uma prática preservacionista e restauradora, de elevado sentido ambiental e ecológico. Assim, reaproveitar ou reutilizar resíduos sólidos de outras atividades ou processos torna-se essencial na prática da engenharia mais moderna e autossustentável.

Diante desse cenário, podem-se citar os resíduos gerados pelas atividades das usinas termelétricas, onde ocorre o processo de geração de energia utilizando carvão mineral como combustível. Nesse processo são gerados resíduos sólidos que podem ser classificados em: escória da caldeira, cinzas pesadas ou bottom ash (mais densas), cinzas leves ou fly ash (menos densas) e o Spray Dryer Ash (SDA) gerado do sistema de dessulfurização dos gases da combustão (FGD).

Conforme Leandro (2005), as pesquisas direcionadas ao aproveitamento das cinzas resultaram, principalmente, no emprego desse material na construção civil, tais como na fabricação de cimento Portland pozolânico utilizando a cinza volante e no uso da cinza pesada como agregado. Contudo, há algumas cinzas produzidas em determinados processos de combustão do carvão mineral com alto teor de enxofre em sua composição, o que inviabiliza o seu uso diretamente na produção de cimentos ou argamassas e concretos.

Considerando que o setor de construção civil e de pavimentação são grandes consumidores de materiais naturais, devido à diversidade e ao volume de insumos usados na produção dos seus serviços, a busca de utilização de rejeitos industriais nesses setores torna-se imperativa.

Dentre todas as possibilidades de emprego de resíduos na construção civil, a substituição das matérias-primas utilizadas na fabricação do concreto vem se mostrando bastante atrativa. O uso de materiais alternativos como substitutos do cimento ou de agregados pode gerar concretos de qualidade satisfatória e contribuir não apenas para a eliminação da necessidade da disposição de resíduos em aterros, mas também para a redução da pressão de um maior uso dos recursos naturais (SANTOS, 2012). 
Tendo em vista o contexto apresentado, esta pesquisa buscou investigar a viabilidade em reaproveitar os resíduos, como as cinzas pesadas, provenientes das termelétricas movidas a carvão mineral para fabricação de Blocos de Concreto para Pavimentos Intertravados (BCPI), substituindo na composição do concreto porcentagens dos agregados naturais por cinzas.

\subsection{Justificativa e problema de pesquisa}

Os resíduos industriais em geral apresentam alguns problemas, tanto pela sua geração, como pela deposição inadequada e também por sua destinação final, causando diversos impactos ambientais, econômicos e sociais. Procurar soluções que reflitam no interesse da sociedade que pressiona por mudanças motivadas pelos elevados custos socioeconômicos e ambientais, é imprescindível. Estes, se manejados adequadamente podem adquirir valor comercial e podem ser utilizados como novas matérias-primas ou novos insumos. O seu uso tende a diminuir o consumo dos recursos naturais, como proporcionar a abertura de novos mercados, gerando trabalho, emprego e renda, conduzindo à inclusão social e diminuindo os impactos ambientais.

Em se tratando de industrias termoelétrica a problemática ambiental relacionada à destinação inadequada de seus resíduos está ligada diretamente ao volume de cinzas geradas pela queima do carvão devido a sua produção diária muito elevada. Os problemas como: limitação das áreas para armazenagem, destinação inadequada dos resíduos, elevados custos na estocagem das cinzas, estimulam a proposição de uma solução de engenharia para dar uma finalidade economicamente sustentável e ambientalmente mais correta, visando assim à conservação e preservação dos recursos naturais.

O uso de blocos intertravados de concreto para pavimentação vem crescendo nas últimas décadas, sendo empregados principalmente em parques, praças, estacionamentos, calçadas, ruas e pátios. O avanço da utilização desse método é devido às suas características, entre elas estão: o baixo custo de manutenção, a liberação do tráfego de pessoas e veículos é imediata, possibilidade de se oferecer materiais alternativos cuja principal preocupação é o equilíbrio entre os aspectos ambientais, sociais e tecnológicos que contribuem para o desenvolvimento dessa técnica prática e confiável de pavimento. Sendo assim, a introdução dos resíduos de termoelétrica, como as cinzas pesadas, na composição dos BCPIs, pode se tornar uma alternativa prática para a pavimentação. 


\subsection{Objetivos}

\subsubsection{Objetivo geral}

O objetivo geral deste estudo é verificar a possibilidade do aproveitamento das cinzas pesadas na produção de blocos de concreto em pavimentos intertravados.

\subsubsection{Objetivos específicos}

(a)Caracterizar todos os agregados (naturais e cinzas) para produção de concreto seco para fabricação de pavers.

(b) Produzir blocos de concreto para pavimentos intertravados substituindo os agregados naturais por cinza pesadas a partir de normas técnicas recomendadas.

(c) Determinar e analisar as propriedades (resistência à compressão simples, resistência à abrasão e absorção de água) dos blocos de concreto para pavimentação, com e sem cinza pesada produzidos com diferentes teores de substituição dos agregados naturais pelas cinzas.

\subsection{Estrutura da dissertação}

Esta dissertação está dividida em cinco capítulos descritos a seguir:

Capítulo 1: apresenta uma contextualização da temática, o problema de pesquisa, a justificativa e os objetivos do estudo.

Capítulo 2: apresenta a revisão bibliográfica dos principais estudos sobre a fabricação de Blocos de Concreto para Pavimentos Intertravados (BCPI), reutilização de resíduos industriais como as cinzas oriundas da queima do carvão mineral, dentre outros.

Capítulo 3: descreve os materiais e métodos escolhidos para se atingir os objetivos estabelecidos.

Capítulo 4: consta da apresentação e da análise dos resultados das etapas realizadas.

Capitulo 5: apresenta as principais conclusões da pesquisa e faz recomendações para trabalhos futuros.

Por fim, as referências bibliográficas e o apêndice estão apresentados após os capítulos deste trabalho. 


\section{REVISÃO BIBLIOGRÁFICA}

Neste capítulo são apresentadas breves considerações da literatura voltadas para pavimentos intertravados e resíduos de usinas Termoelétricas (cinzas).

\subsection{Histórico e principais conceitos sobre pavimentos intertravados}

O histórico do pavimento intertravado confunde-se com a história da pavimentação. O desenvolvimento dessa técnica de pavimentação resultou em uma evolução de procedimentos, dos quais se encontram relatos de 2500 anos, com a colocação de pedras justapostas em seu estado natural (CRUZ, 2003; MULLER, 2005).

Na perspectiva de Muller (2005) e Fioriti (2007), uma das mais antigas estradas com as características de intertravamento de que ainda se encontram vestígios está na Grécia, revestida com pedra e construída, provavelmente, em 1.500 a.C. Outro exemplo é a via Ápia que ligava a cidade de Roma até o sul da Itália. Essa via foi pavimentada por construtores da época e a maior parte de sua extensão foi feita com pequenas peças de pedras aparelhadas em forma octogonal (CRUZ, 2003). A Figura 1 mostra uma estrada construída pelos romanos na época da extensão do seu império.

Figura 1 - Estrada antiga, Via Ápia, construída com características de intertravamento

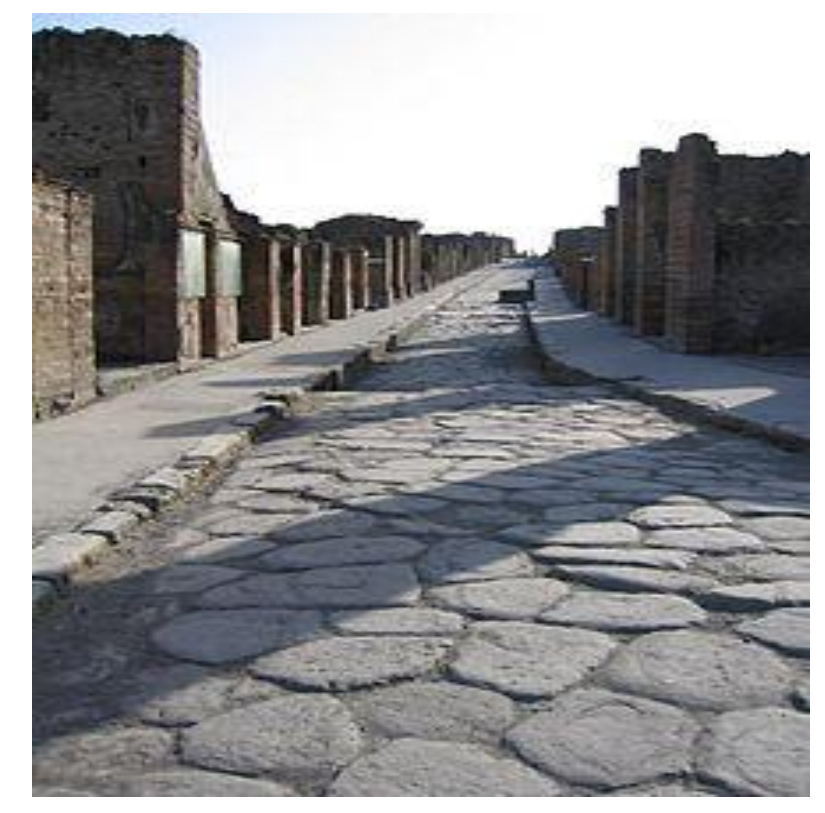

Fonte: Google imagens (2018). 
Segundo Cruz (2003), no século XVIII, já se tinha preocupação em manter as juntas estreitas entre as peças. Nesse mesmo período surgiram os modelos de assentamento em fileiras ou tipo espinha de peixe. No século XX, para atenuar o barulho causado pelo tráfego, foi iniciada a prática de selar as juntas com argamassa de cimento ou com uma mistura de asfalto e areia.

Segundo Fioriti (2007), esse tipo de pavimento vem conquistando espaço em todo o país, pois as empresas que trabalham nesse ramo argumentam as vantagens que o sistema oferece. Reconheceu-se rapidamente que os pavimentos intertravados de concreto proporcionavam melhor uniformidade do que os assentamentos de pedra e que evitavam a necessidade de revestir as faces dos blocos antes da sua colocação (SHACKEL, 1990; CRUZ, 2003; GODINHO, 2009).

Os blocos de concreto ou Pavers, como são conhecidos, são blocos intertravados, pré-fabricados, maciços e que permitem pavimentar completamente uma superfície conforme citado em Fernandes (2016). Os primeiros pavers foram patenteados pelo alemão Fritz Von Langsdorff, em 1960, como uma alternativa de gerar emprego e de reconstruir cidades arrasadas pela guerra. A grande parte do desenvolvimento dos pavimentos intertravados de concreto ocorreu na Alemanha, na cidade de Stuttgart em 1963, sendo a primeira cidade a ser pavimentada com pavers.

De acordo com Godinho (2009) e Fernandes (2016), a Alemanha é o maior produtor mundial de pavers com mais de 200 milhões de $\mathrm{m}^{2}$ por ano e também possui o maior número de máquinas de grande porte para fabricação e está sempre na vanguarda. Na Holanda, provavelmente o segundo maior polo no mundo, inventaram um paver que absorve a poluição do ar, conhecido como paver fotocatalítico. Na América Central, outro grande polo de tecnologias de equipamentos, o paver foi adotado a partir do início da década dos anos 70 e logo chegou ao Brasil onde se popularizou a partir de 2000.

\subsection{Formato, tipologia e forma dos BCPI}

O uso bem-sucedido na Alemanha dos blocos de concreto em pavimentos e suas formas logo foram copiados em todo o mundo. No entanto, a Holanda persistiu no uso de unidades retangulares, mas os principais avanços na pavimentação de blocos de concreto seguiram com a introdução de novas formas, moldadas em meados de 1950 (SHACKEL, 1990).

Os pavers de concreto foram originalmente desenvolvidos como substitutos de tijolos de construção (maciços) ou assentamentos de pedra. De fato, isso se refletiu na 
terminologia ainda usada na Europa e na América, onde o produto é conhecido como pedras de concreto. A partir da década de 1950, houve uma evolução constante dos modelos de formas existentes (SHACKEL, 1990; CRUZ, 2003). A Figura 2 apresenta os primeiros blocos que simplesmente imitavam os conjuntos de pedra ou tijolos de construção para os quais eles deveriam substituir.

Figura 2 - Primeira forma, planta e perfil de blocos
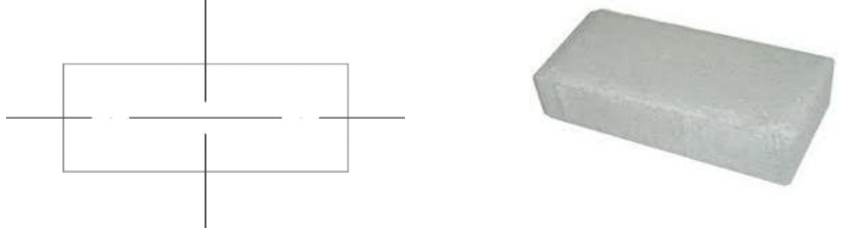

Fonte: Elaborada pela Autora (2017).

Segundo Cruz (2003) e Shackel (1990), entre as décadas de 1960 e 1970 aumentouse a utilização dos blocos nos Estados Unidos, Europa, América do Sul, América Central, Austrália, Nova Zelândia e Japão. A fabricação dos pavimentos pré-moldados de concreto teve um avanço no mundo todo nessa época, onde pelo menos 200 tipos de formas e uma variedade de equipamentos para fabricação foram comercializados.

A fabricação anual no mundo, em 1980, já ultrapassava 45 milhões de $\mathrm{m}^{2}$, sendo que mais da metade eram utilizados em vias de tráfego urbano e no final da década de 1990, a produção chegou a $100 \mathrm{~m}^{2}$ por segundo durante os dias úteis de trabalho. A fabricação dos blocos que era comum na Europa, teve espaço também no Brasil, tanto em vias quanto em calçamentos, proporcionando um equilíbrio entre aspectos ambientais, tecnológicos e econômicos, fator que determinou o amplo desenvolvimento e expansão dos pavers. Desde então, a pavimentação com blocos intertravados de concreto vem crescendo em grandes proporções no mundo todo. (SMITH 2003; FIORITI, 2007; GODINHO, 2009).

Em resumo, os intertravados são peças de concreto ou pedras talhadas com diversas formas, cores e texturas que, dispostas em conjunto, criam grandes áreas de superfícies pavimentadas, destinadas à utilização por pessoas e veículos leves ou pesados e popularizou-se pelo mundo durante as últimas décadas. Com o passar dos anos, foi incorporado um refinamento maior nas formas das peças, disponibilizando outros modelos de peças com formatos dentados, principalmente e os benefícios práticos para o assentamento das peças eram facilmente detectados. Por fim, o desenvolvimento da pavimentação permitiu relacionar a escolha da forma geométrica com o desempenho do pavimento, em função do tipo de tráfego (CRUZ, 2003; ARY JÚNIOR, 2007). 
Baseado em Wiebbelling (2015), alguns modelos se destacam por serem mais utilizados. O único requisito recomendado com relação ao formato dos blocos é que ele seja capaz de permitir o assentamento em combinação bidirecional. Na Tabela 1, apresentam-se alguns dos formatos possíveis para os blocos intertravados de concreto fabricados no mundo durante as últimas décadas.

Tabela 1 - Formatos dos Blocos Fabricados no Mundo nas Últimas Décadas

Descrição
- Peças de concreto segmentadas ou retangulares, com
relação comprimento/largura igual a dois (usualmente 20
cm $\times 10 \mathrm{~cm}$, comprimento $\times$ largura);
- Entrelaçam entre si nos quatro lados;
- Capazes de serem assentados em fileiras ou em "espinha-
de-peixe';
- Facilmente carregados com apenas uma mão; $\begin{aligned} & \text { - Peças de concreto com tamanhos e proporções similares } \\ & \text { aos da categoria anterior; } \\ & \text { - Entrelaçam entre si somente em dois lados; } \\ & \text { - Assentadas apenas em fileiras; } \\ & \text { - Facilmente carregados com apenas uma mão; } \\ & \text { - Genericamente tem o formato em "I"; }\end{aligned}$

Fonte: Adaptado por HALLACK, 1998; CRUZ, 2003.

Mais recentemente, novas e importantes mudanças ocorreram com a iniciativa de desenvolver um melhor assentamento mecânico, obedecendo às tipologias de formatos e dimensionamentos exigidos pela Associação Brasileira de Normas Técnicas (ABNT) - Norma Brasileira Regulamentadora (NBR) 9781:2013 exemplificados na Tabela 2. 
Tabela 2 - Peças de Concreto para Pavimentação Normatizadas

\begin{tabular}{cl}
\hline Tipos de peças & \multicolumn{1}{c}{ Descrição de acordo com a ABNT NBR 9781:2013 } \\
\hline I & $\begin{array}{l}\text { Peças de concreto com formato próximo ao retangular, com relação } \\
\text { comprimento/largura igual a dois, que se arranjam entre si nos quatro } \\
\text { lados e podem ser assentadas em fileiras ou em espinha de peixe, } \\
\text { ilustrados na Figura } 3 \text { (a). }\end{array}$ \\
\hline II & $\begin{array}{l}\text { Peças de concreto com formato único, diferente do retangular e que } \\
\text { só podem ser assentadas em fileiras, ilustrados na Figura } 3 \text { (b). }\end{array}$ \\
\hline II & $\begin{array}{l}\text { Peças de concreto com formatos geométricos característicos, como } \\
\text { trapézios, hexágonos, triedros, etc., com pesos superior a } 4 \text { kg, } \\
\text { ilustrados na Figura 3 (c). }\end{array}$ \\
\hline IV & $\begin{array}{l}\text { Conjunto de peças de concreto de diferentes tamanhos, ou uma única } \\
\text { peça com juntas falsas, que podem ser utilizadas com um ou mais } \\
\text { padrões de assentamento, ilustrados na Figura } 3(\mathrm{~d}) .\end{array}$ \\
\hline
\end{tabular}

Fonte: Adaptado pela Autora (Anexo D - ABNT NBR 9781:2013).

As Figuras 3 (a), (b), (c) e (d) ilustram, conforme recomendações da ABNT NBR 9781:2013, as formas das peças de concreto padronizadas atualmente no Brasil. Os blocos intertravados podem ser fabricados em qualquer um desses formatos.

Figura 3 - Exemplos de peças de concreto dos tipos I, II, III e IV

(a) Peças de concreto Tipo I

(b) Peças de concreto Tipo II

(c) Peças de concreto Tipo III
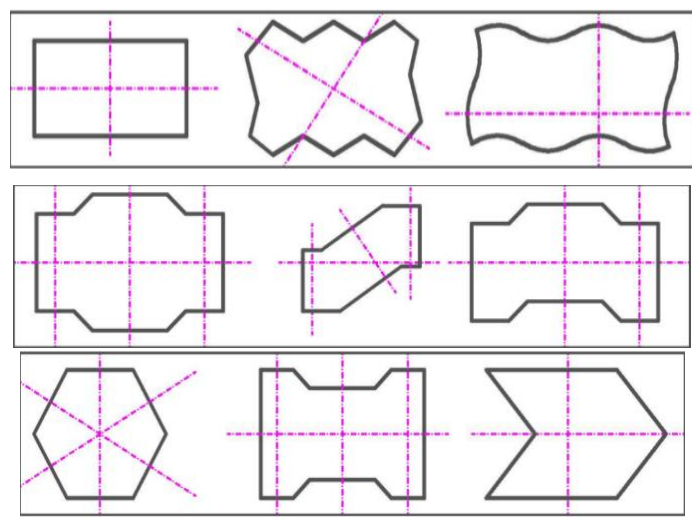

(d) Peças de concreto Tipo IV

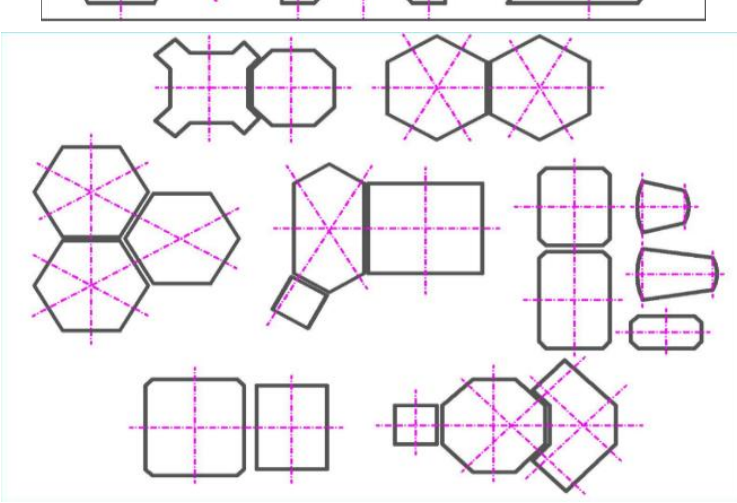

Fonte: Adaptado pela Autora de (Anexo D - ABNT NBR 9781:2013 
Alguns modelos se destacam por serem mais utilizados, os tipos I e II da ABNT NBR 9781:2013. Os pesquisadores ainda não entraram num consenso sobre qual é o melhor formato dos blocos intertravados. O único requisito recomendado com relação ao formato dos blocos é que ele seja capaz de permitir o assentamento em combinação bidirecional. Escolhido os formatos ou tipologias e confeccionando as peças, monta-se o pavimento como um "quebra cabeça" onde as peças se encaixam uma a uma de forma desenhada aleatória ou seguindo projeto de paisagismo, se houver, ou simplesmente encaixando-as sobre uma base de areia.

\subsection{Materiais empregados na fabricação dos BCPI}

$\mathrm{Na}$ antiguidade em algumas localidades eram utilizados solos arenosos misturados com seixos ou pedras naturais talhadas no formato de paralelepípedos, ou tijolos cerâmicos e madeiras. Há relatos de que a primeira peça pré-moldada de concreto ou bloco de concreto foi fabricada no final do século XIX e algumas patentes foram registradas antes da primeira guerra mundial. De acordo com Cruz (2003), os primeiros avanços no desenvolvimento da utilização da pavimentação de blocos de concreto intertravados ocorreram na Holanda e Alemanha, no período de reconstrução dos países após a Segunda Guerra Mundial, utilizando materiais alternativos e resíduos.

Atualmente, para a fabricação de blocos intertravados de concreto são utilizados normalmente os seguintes materiais: cimento Portland, agregados graúdos, agregados miúdos (naturais, artificiais ou reciclados), água e podem ser utilizados adições minerais, aditivos químicos e pigmentos de base inorgânica.

\subsubsection{Cimento Portland}

O cimento é composto de clínquer e adições que são misturadas ao clínquer na fase de moagem e que podem variar de um tipo de cimento para outro, sendo elas um dos fatores que definem os diferentes tipos de cimento. Em função do tipo e teor de adições, são normatizados ABNT.

Existem no Brasil vários tipos de cimento Portland, diferentes entre si, principalmente em função de sua composição. Os mais utilizados na fabricação de pavers são:

a) Cimento Portland composto - tipo CP-II (ABNT NBR:16697):

- Com adição de escoria: tipo CP-II E;

- Com adição de materiais pozolânicos: tipo CP-II-Z; 
- Com adição de materiais carbonáticos: tipo CP-I-F.

b) Cimento Portland de Alta Resistência Inicial (ARI) - tipo CP-V (ABNT NBR: 16697);

$\mathrm{Na}$ fabricação dos blocos intertravados de concreto, pode-se utilizar quaisquer citados anteriormente, independentemente do tipo, desde que atendam às recomendações técnicas normativas (ABNT NBR 9781:2013). Segundo Pettermann (2006), o cimento influencia muito na resistência mecânica, porém as regulagens, o tipo de equipamento utilizado, as formas de vibração também são importantes e têm influência na resistência dos blocos intertravados de concreto.

\subsubsection{Agregados Graúdos}

Os agregados graúdos utilizados na fabricação dos blocos de concreto intertravados podem ser resultantes do britamento de rochas, cascalhos ou seixos rolados. Os agregados, cujos grãos ficam retidos na peneira de $4,75 \mathrm{~mm}$, dependem muito da região em que estão sendo fabricados os blocos.

A forma do agregado deve ser, preferencialmente, do tipo cúbico ou esférico. As demais características deverão estar em conformidade com a ABNT NBR 7211:2009. De acordo com Wiebbelling (2015) são utilizadas brita $19 \mathrm{~mm}$ e 12,5 mm como agregados graúdos por apresentarem, geralmente, uma melhor aderência com a pasta de cimento, favorecendo a obtenção de resistências mecânicas mais elevadas.

\subsubsection{Agregados Miúdos}

Os agregados miúdos são considerados como os grãos que passam pela peneira com abertura de malha 4,75 mm e ficam retidos na peneira com abertura de malha de $150 \mu \mathrm{m}$, conforme ensaio realizado de acordo com a ABNT NBR NM 248:2003. As demais características obedecerão a ABNT NBR7211:2009.

Pettermann (2006) aconselha que na fabricação dos blocos intertravados de concreto, pode-se utilizar areia natural quartzosa, agregados miúdos artificiais, como pó de brita, proveniente do processo de britamento de rochas estáveis para produção de agregados graúdos. Deve-se ter cuidado com o formato mais anguloso e alongado dos grãos, pois dificulta a moldagem dos blocos e também requer mais pasta de cimento para produzir misturas mais trabalháveis. 


\subsection{4 Água}

A água recomendada para a fabricação dos blocos intertravados de concreto deve estar isenta de substâncias que possam prejudicar as reações de hidratação do cimento, atendendo à ABNT NBR 15900-1:2009, assim, pode ser utilizada sem restrição para a preparação de concreto. É de fundamental importância que ela esteja livre de impurezas, para não provocar reações indesejáveis no concreto, alterando, assim, o desempenho da peça. As demais características deverão estar também em conformidade com a referida norma.

\subsubsection{Aditivos}

Os aditivos são produtos químicos que podem ser usados na composição do concreto e/ou argamassa, adicionados durante o processo de sua preparação, tendo como objetivo modificar as suas propriedades no estado fresco e/ou no estado endurecido, em quantidade não maior que 5\% da massa de material cimentício contida no concreto. Em geral, atuam frequentemente nas propriedades reológicas do concreto e alteram as reações de hidratação do cimento: melhoram a trabalhabilidade, modificam a viscosidade, atuam na retenção de água, aceleram ou retardam o tempo de pega, controlam o desenvolvimento de resistências mecânicas, intensificam a resistência à ação do congelamento, diminuem a fissuração térmica, atenuam as consequências do ataque por sulfatos, reação álcali-agregado e corrosão de armadura, entre outras propriedades. A efetividade de cada tipo de aditivo pode variar dependendo de sua concentração no concreto e para cada finalidade há um ou mais aditivos adequados conforme ABNT NBR 11768:2011.

\subsubsection{Pigmentos}

Os pigmentos são produtos que adicionados ao concreto os tornam coloridos. Esses devem ser inorgânicos (base óxido) e devem atender à ABNT NBR 11768:2011 para que o bloco seja resistente à alcalinidade do cimento, aos raios solares e às intempéries. É importante o cuidado na dosagem do concreto, pois os pigmentos, sendo inorgânicos, alteram a trabalhabilidade do concreto, exigindo a adição de mais água na mistura, o que ocasiona a redução na resistência nos concretos plásticos. Pode-se facilmente encontrar no mercado esses pigmentos à base de óxido (EMPRESA T\&A, 2005), conforme pode ser visto na Tabela 3. 
Tabela 3 - Pigmentos Inorgânicos para Colorir as Peças de Concreto

\begin{tabular}{cc}
\hline Cor do Concreto & Especificação do Pigmento \\
\hline Vermelho & Óxido de ferro vermelho $\left(\alpha-\mathrm{Fe}_{2} \mathrm{O}_{3}\right)$ \\
Preto & Óxido de ferro preto $\left(\mathrm{Fe}_{2} \mathrm{O}_{4}\right)$ \\
Amarelo & Óxido de ferro amarelo $(\alpha-\mathrm{FeOOH})$ \\
Marrom & Óxido de ferro marrom (mistura de $\left.\alpha-\mathrm{Fe}_{2} \mathrm{O}_{3}, \alpha-\mathrm{FeOOH} \mathrm{e} \mathrm{Fe}_{2} \mathrm{O}_{4}\right)$ \\
Verde & Óxido de cromo $\left(\mathrm{Cr}_{2} \mathrm{O}_{3}\right)$ \\
Azul & Óxido de cobalto $\left(\mathrm{Co}\left(\mathrm{Al}_{1} \mathrm{Cr}_{2}\right) \mathrm{O}_{4}\right)$ \\
\hline
\end{tabular}

Fonte: Adaptado pela Autora (EMPRESA T \& A, 2018).

\subsection{Dosagem do concreto}

Entende-se por estudo de dosagem dos concretos de cimento Portland, os procedimentos necessários à obtenção da melhor proporção entre os materiais constitutivos do concreto, também conhecido por traço. Essa proporção ideal pode ser expressa em massa ou em volume. Em geral, deve-se considerar como materiais possíveis de serem utilizados em um estudo de dosagem: os vários tipos de cimentos, os agregados miúdos, os agregados graúdos, a água, o ar, os aditivos, as adições e os pigmentos. Em relação aos agregados graúdos e miúdos, pode ser feita a distinção entre agregados reciclados, artificiais industrializados e naturais.

A dosagem, também é chamada de seleção de materiais, segundo Neville (1995), é o processo de escolher os ingredientes do concreto e determinar suas quantidades relativas, com o objetivo de produzir o mais econômico concreto possível, atendendo propriedades importantes como resistência, durabilidade e tipo de consistência requerida.

Embora os métodos de dosagem possam diferir entre si, certas atividades são comuns a todos, como por exemplo, o cálculo da resistência média de dosagem, a correlação da resistência à compressão com a relação água/cimento para determinado tipo e classe de cimento. Isso acontece quando um estudo de dosagem tem por objetivo a obtenção de uma resistência especificada, sem descuidar da economia e da sustentabilidade que sempre devem nortear um estudo de dosagem.

\subsubsection{Concreto utilizado na fabricação dos BCPI (Concreto Seco)}

O concreto é um material composto que consiste, essencialmente, de um meio contínuo aglomerante, dentro do qual estão mergulhadas partículas ou fragmentos de 
agregados. No concreto de cimento hidráulico, o meio aglomerante é formado por uma mistura de cimento e água (MEHTA e MONTEIRO, 1994). Os concretos que possuem como aglomerante o cimento Portland, têm inúmeras aplicações e finalidades. Dentre eles, pode-se citar: os concretos plásticos e os concretos "secos". Como exemplo de concretos plásticos, pode-se citar o convencional utilizado em obras de concreto armado e o concreto graute. Já o concreto "seco" é empregado na produção de pavers, blocos de alvenaria estrutural, tubos e concreto compactado a rolo.

Existem diversas diferenças que distinguem esses grupos de concreto tais como: a forma como o ar aprisionado às misturas é removido, a trabalhabilidade e o abatimento, a granulometria final, a relação água/materiais secos, os processos de produção entre outras (PIROLA, 2011).

O “concreto seco", também chamado de concreto sem abatimento (no-slump), difere bastante do "concreto convencional" (plástico, baixa coesão no estado fresco, reduzido teor de água e baixo teor de umidade. Segundo Juvas (1993), no concreto seco, a água tem a função prioritária de participar das reações de hidratação do cimento, enquanto no concreto plástico a pasta ocupa os espaços deixados pelos agregados. No concreto seco existe uma presença significativa de ar. Quanto menos água é adicionada na mistura até o seu "ponto ótimo", maior a sua resistência, oposto ao que acontece aos concretos convencionais que seguem a "Lei de Abrams" onde a resistência do concreto é proporcional a relação água/cimento (TANGO, 1994; OLIVEIRA 2004).

No estado fresco, as características mais importantes do concreto seco são a trabalhabilidade e a coesão. Segundo Mota (2014), a trabalhabilidade é definida como a propriedade que determina o esforço mínimo exigido para manipular uma quantidade de concreto, com perda mínima de homogeneidade e depende do teor de umidade, do formato, da textura dos agregados e do empacotamento das partículas. A coesão entre as partículas deve ser suficiente para que, após a moldagem, o concreto permaneça íntegro desde a prensagem à desforma. Essa coesão é obtida pelo emprego adequado de cada material, e depende do teor de finos, do formato e porosidade dos agregados. A coesão da mistura pode ser melhorada através do aumento do teor de finos da mistura, onde o responsável pela maior contribuição é o próprio cimento. Essa propriedade também depende do formato das partículas, onde aquelas que são arredondadas e com bordas suaves resultam em melhor coesão. Os finos têm a característica de formar a pasta que preenche os vazios entre os grãos maiores (DOWSON, 1980; MEHTA; MONTEIRO, 2008). 
No concreto seco, as propriedades no estado endurecido estão intimamente ligadas às do estado fresco, de forma muito mais pronunciada do que no concreto plástico (RODRIGUES, 1984). O concreto seco deve apresentar trabalhabilidade adequada a ser moldado com o equipamento disponível, além de demandar uma elevada coesão para que as peças se mantenham inalteradas após a desforma. Para pavers, as principais propriedades requeridas no estado endurecido são: resistência à compressão, durabilidade e textura superficial da peça, que está relacionada com a composição granulométrica da mistura, e durabilidade, sendo essa última normalmente avaliada pela resistência à abrasão. Essas propriedades estão ligadas, além dos materiais empregados, com o tipo e regulagem dos equipamentos utilizados. Segundo Mota (2014), o crescimento da resistência do concreto depende do tipo e do consumo de cimento e ainda do processo de cura utilizado que devem ser adequados ao processo. A resistência mecânica também é diretamente relacionada à capacidade de compactação do equipamento e ao teor de umidade da mistura, e também da distribuição granulométrica dos agregados. Já a durabilidade está relacionada com a capacidade do concreto em resistir à ação da água e a ataques químicos.

\subsection{Recomendações no processo de produção e aprovação dos BCPI}

A Norma Brasileira, que retrata a produção de pisos intertravados de concreto para pavimento é a ABNT NBR 9781:2013 - "Peças de concreto para pavimentação - especificações e métodos de ensaio" que descreve algumas recomendações para produção dos blocos que estão comentadas a seguir:

a) Avaliação dimensional das peças: deve ser realizada sempre em planos paralelos ou perpendiculares às arestas das peças, conforme sua tipologia, descritas no Anexo D da ABNT NBR 9781:2013, considerando que as variações máximas permissíveis nas dimensões são de $3 \mathrm{~mm}$, no comprimento e largura das peças, e de $5 \mathrm{~mm}$ na altura das peças.

b) Inspeção visual das peças: devem ser inspecionadas visualmente, objetivando a identificação de peças com defeitos e devem apresentar aspecto homogêneo, arestas regulares e ângulos retos, e devem ser livres de rebarbas, defeitos, delaminação e descamação.

c) Absorção de água: as peças ensaiadas devem apresentar valor médio menor ou igual a $6 \%$ de umidade, não sendo admitido nenhum valor individual maior do que $7 \%$. A absorção representa o incremento de massa de um corpo sólido 
poroso devido à penetração de água em seus poros permeáveis, em relação à sua massa em estado seco.

d) Resistência característica à compressão: têm-se dois parâmetros a serem considerados: a solicitação para qual tipo de tráfego deve ser empregado e a resistência aos 28 dias, descritos na Tabela 4.

e) Resistência à abrasão: ensaio facultativo, mas quanto especificada deve atender as especificações descritas na Tabela 4.

Tabela 4 - Resistência Característica à Compressão dos BCPI

\begin{tabular}{ccc}
\hline Solicitação & $\begin{array}{c}\text { Resistência característica à } \\
\text { compressão }\left(\mathbf{f}_{\mathbf{p k}}\right)(\mathbf{M P a})\end{array}$ & $\begin{array}{c}\text { Cavidade } \\
\text { máxima }(\mathbf{m m})\end{array}$ \\
\hline $\begin{array}{c}\text { Tráfego de pedestres, veículos leves e } \\
\text { veículos comerciais de linha }\end{array}$ & $\geq 35$ & $\geq 23$ \\
\hline $\begin{array}{c}\text { Tráfego de veículos especiais e } \\
\text { solicitações capazes de produzir efeitos } \\
\text { de abrasão acentuados }\end{array}$ & $\geq 50$ & $\geq 20$ \\
\hline
\end{tabular}

Fonte: Adaptado pela Autora (ABNT NBR 9781:2013).

A fabricação dos blocos ocorre basicamente por duas formas: manual e mecanizada por meio de vibroprensas. No processo manual utilizam-se fôrmas plásticas, metálicas ou de madeira preenchidas com concreto, na maioria das vezes rodados em betoneira (GREGORIO, 2012).

Os pavers produzidos manualmente possuem um padrão de qualidade significativamente inferior aos blocos prensados por máquinas hidráulicas ou pneumáticas (CLEMENTINO, 2013). De acordo com Bitencourt (2014), a fabricação dos pavers é classificada em três tipos distintos: as peças dormidas, as peças viradas e as peças vibroprensadas.

As peças dormidas são produzidas de forma manual. Nesse processo, o concreto é lançado nas formas onde fica de um dia para o outro, procedendo a desmoldagem no dia seguinte da moldagem. Como os moldes são de plástico, de aço ou de fibra, esse processo gera peças com um acabamento superficial mais liso, resultando em uma aparência estética mais agradável. Segundo Fernandes (2016), esse processo resulta em menor consumo de cimento em virtude da facilidade de produção em duas camadas: uma externa fina para acabamento e uma interna com bastante agregado graúdo. $\mathrm{O}$ seu ponto fraco é a baixa produtividade e o formato 
cônico do molde para facilitar a desforma do concreto depois de endurecido. As Figuras 4 (a) e (b) ilustram fôrmas do Tipo I utilizadas na produção do paver pelo processo dormido.

Figura 4 - Exemplos de formas utilizadas no processo dormido

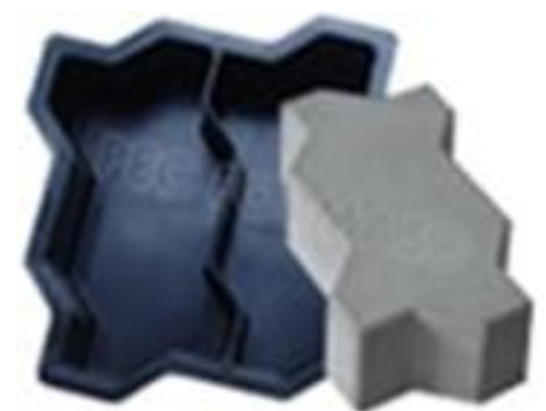

(a) Formato espinha de peixe"

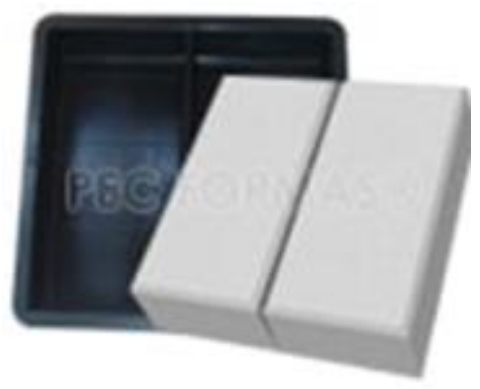

(b) Formato tijolinho

Fonte: Site: PEC MAQ \& PEC FORMAS (2018).

As peças viradas são produzidas de fôrma manual e mecânica. Nessa forma de processo produtivo é usado o concreto em fôrmas conjuntas ou individuais, adensadas em mesa vibratória e desmoldadas logo após a moldagem em uma base plana e impermeável (BITENCOURT, 2014). Nesse método, o consumo de cimento é baixo, devido à possibilidade do emprego de duas camadas. Como ponto positivo tem-se a obrigatoriedade de trabalhar com o concreto na umidade ótima. Como ponto negativo a peça pode ter o acabamento prejudicado pelo fato da desforma acontecer com o concreto ainda no estado fresco. Além disso, a produtividade é ainda menor que a do processo dormido (FERNANDES, 2016). A Figura 5 ilustra uma mesa vibratória utilizada na produção do paver pelo processo virado.

Figura 5 - Tipo de mesa vibratória

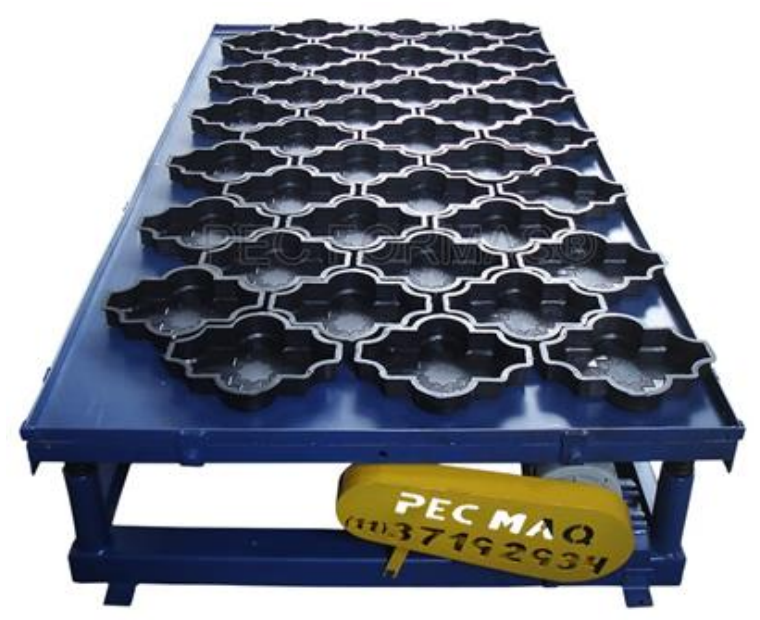

Fonte: Site PEC MAQ \& PEC FORMAS (2018). 
As peças vibroprensadas, segundo a Associação Brasileira de Cimento Portland (ABCP )2010, são peças de concreto produzidas industrialmente por máquinas conhecidas como vibroprensas que proporcionam elevada compactação às peças, aumentando sua resistência mecânica e durabilidade. O processo vibroprensado é o processo de fabricação de paver mais utilizado no mundo e o que resulta em melhor desempenho estético do produto aplicado. Altamente mecanizado, é o que proporciona a mais alta produtividade com baixíssimo consumo de mão de obra (FERNANDES, 2016). Nesse processo, o paver é produzido em vibroprensas, equipamentos multifuncionais que podem ser utilizados na produção de uma grande família de produtos de artefatos de cimento, tais como: blocos de concreto, tijolos, meios-fios, grelhas, pavers e placas (BITTENCOURT, 2012). Também chamada de máquina de vibrocompressão ou vibro-prensas multifuncionais, essa máquina é o principal componente do layout e o coração do processo produtivo em uma indústria fabricante de artefatos de concreto no sistema vibroprensado.

Essa denominação, vibroprensa, advém do tipo de mecanismo empregado para fazer com que o material de dosagem penetre e preencha as fôrmas de aço do equipamento. Esses equipamentos produzem em escala e têm os seguintes benefícios: o controle de homogeneidade das resistências mecânicas, textura e dimensões que podem ser exercidos durante a fabricação dos produtos (PIROLA, 2011; FIORITI,2007). A Figura 6 ilustra um dos diversos modelos de máquina vibro-prensa hidráulica utilizada na produção do paver.

Figura 6 - Máquina para blocos do tipo vibro-prensa hidráulica
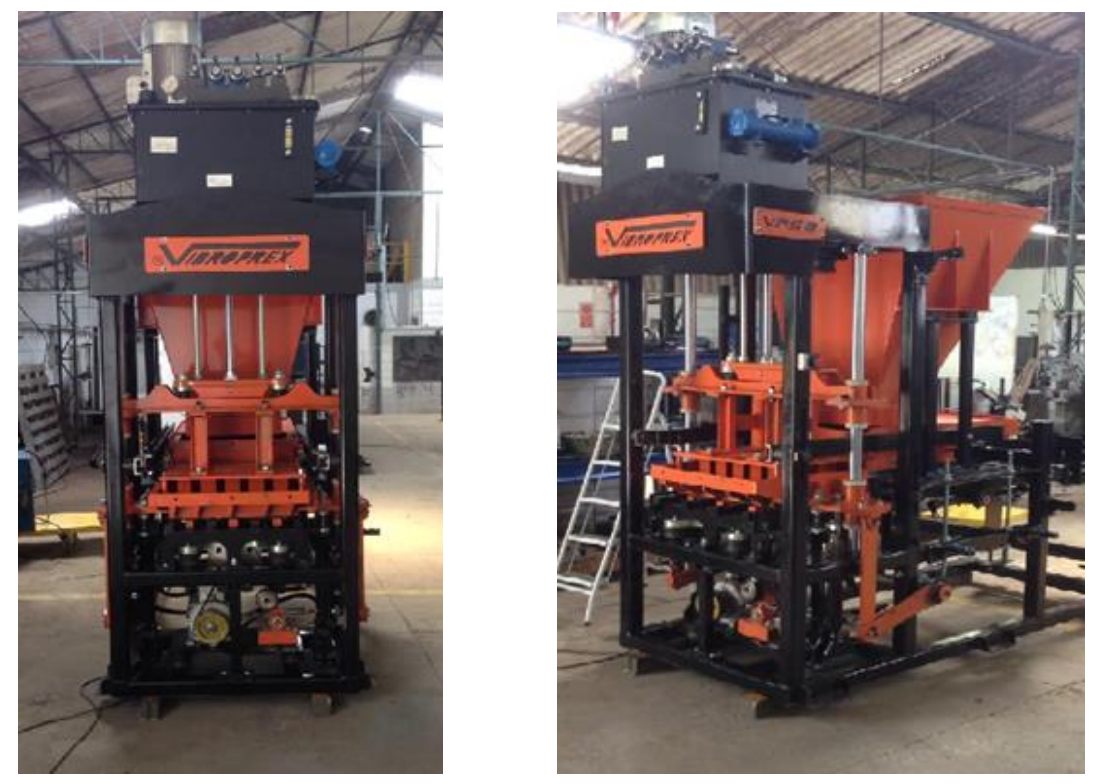

Fonte: Autora (2018). 
O processo mais recomendado e utilizado para a produção de blocos de concreto normatizados é através das vibroprensas, por meio de prensas acionadas por pistões, garantindo as características especificadas para o bloco (FERNANDES, 2016). Seguindo as recomendações da EMPRESA T\&A (2004), o processo de fabricação através de vibroprensas pode ser dividido em 5 etapas principais:

a) Dosagem do concreto: todos os materiais são dosados em peso automaticamente em proporções previamente definidas, de acordo com o traço já estabelecido pela equipe técnica e pelo laboratório;

b) Mistura: toda a matéria-prima é transferida para o misturador para ser homogeneizada e transformada em concreto;

c) Moldagem: é a etapa de vibro-prensagem do produto. Do misturador, o concreto segue para alimentação da máquina, onde ocorrerá a prensagem e a vibração que devem ser realizadas com grande energia de compactação;

d) Cura: após a moldagem, as peças seguem para as câmaras de cura totalmente estanques, ambientes com temperatura e umidade controladas. As peças devem permanecer nessas câmaras pelo tempo necessário para garantir a maior hidratação do cimento e consequentemente a qualidade final do produto;

e) Estocagem: depois da retirada das peças das câmaras de cura, essas são dispostas em pallets de madeira e marcadas quanto ao lote de identificação.

\subsection{Estrutura do Pavimento Intertravado}

De acordo com Senço (1997), o pavimento é a estrutura construída sobre a terraplenagem e destinada, econômica, técnica e simultaneamente a: (i) resistir e distribuir os esforços verticais oriundos do tráfego; (ii) melhorar as condições de rolamento quanto ao conforto e segurança e (iii) resistir aos esforços horizontais (desgaste), tornando mais durável a superfície de rolamento.

A estrutura do pavimento intertravado de concreto é composta pelas seguintes camadas: sub-leito, reforço do sub-leito, sub-base, base e revestimento. A camada superior é constituída por peças de concreto justapostas em uma camada de assentamento/colchão de areia cujas juntas entre as peças são preenchidas por material de rejuntamento e o intertravamento do sistema é proporcionado pela contenção lateral, em geral, por meio-fio. A Figura 7 representa um modelo de estrutura de pavimento intertravado com peças de concreto do tipo pavers. 
Figura 7 - Seção transversal típica das camadas do pavimento intertravado

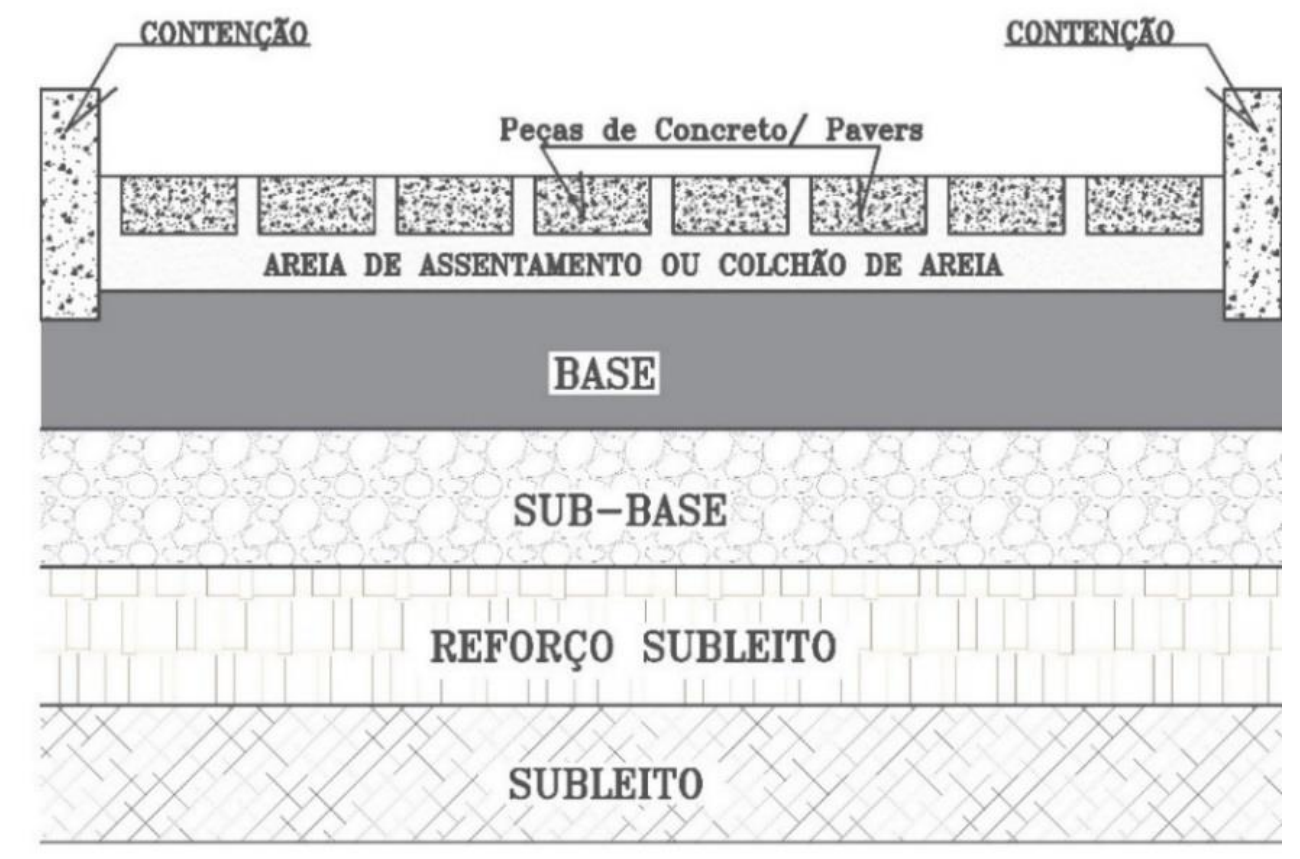

Fonte: Adaptada pela Autora (SENÇO, 1997; CARVALHO, 1998; BITTENCORT, 2012).

De acordo com Wiebbelling (2015), as espessuras das camadas que compõem o pavimento intertravado dependem: (i) da intensidade do tráfego que circulará sobre o pavimento (tráfego de pedestres e veículos leves ou tráfego de veículos leves e poucos veículos pesados); (ii) das características do terreno de fundação e (iii) da qualidade dos materiais constituintes das demais camadas. Serão descritas, a seguir, as características básicas de alguns desses elementos algumas especificações para o controle de execução, conforme Carvalho (1998).

\section{a) Subleito:}

O subleito, considerado o terreno de fundação do pavimento que tem o objetivo de suportar as cargas provenientes do tráfego, deve estar regularizado e compactado, na altura do projeto, antes da introdução das camadas posteriores. O subleito será considerado concluído quando sua capacidade, comumente expressa pelo Índice de Suporte Califórnia (ISC), for igual ou maior do que $2 \%$ e ter expansão volumétrica máxima de $2 \%$ ou conforme for especificado em projeto (CARVALHO, 1998).

\section{b) Reforco do subleito:}

Camada granular de pavimentação, com espessura variável, definida de acordo com o projeto do pavimento, cuja finalidade é melhorar a capacidade de suporte de carga do subleito, executada sobre o subleito, devidamente compactado e regularizado. Utilizada quando se torna necessário reduzir espessuras elevadas da camada de sub-base, originadas pela baixa 
capacidade de suporte do subleito, de acordo com o Departamento Nacional de Infraestrutura de Transportes (DNIT) 138:2010.

\section{c) Sub-base:}

O material de sub-base também será definido pelo valor de CBR mínimo definido em função do tráfego e das condições de suporte de subleito (CARVALHO, 1998). Para Fioriti (2007) a sub-base pode ser granular, solo escolhido, solo-brita ou tratado com aditivos, como por exemplo solo melhorado com cimento Portland. O material da sub-base também será definido pelo valor de ISC mínimo necessário.

\section{d) Base:}

Conforme Cruz (2003), a base é a camada que recebe as tensões distribuídas pela camada de revestimento e tem como função principal proteger estruturalmente o subleito das cargas externas, evitando deformações e deterioração do pavimento intertravado.

\section{e) Camada de assentamento ou colchão de areia:}

Carvalho (1998) relata que no Brasil a camada de assentamento dos blocos será composta de areia e que a forma dos grãos utilizado interfere diretamente no comportamento e na deformação do pavimento intertravado, porque as partículas angulares têm maior coeficiente de atrito, o que provoca melhor distribuição dos esforços. Segundo Cruz (2003), uma espessura excessiva torna-se uma fonte potencial de deficiências no assentamento.

\section{f) Camada de rolamento - Pecas de concreto ou Pavers:}

De acordo com Carvalho (1998), a camada de rolamento é formada pelas peças de concreto, sendo que a sua construção compreende três etapas: colocação, acabamento junto às bordas de meios-fios ou qualquer interrupção no pavimento (bueiros, caixas de inspeção etc.) e vibração sobre as peças na área já executada. Também, responsável por suportar a abrasão provocada pelo tráfego e pelo intemperismo, contribuindo com a capacidade estrutural do pavimento.

\section{g) Contencão:}

O confinamento lateral, externo e interno, garante tal condição quando houver um rejuntamento efetivo das peças de concreto. É responsável pelo travamento da estrutura da camada de rolamento (WIEBBELLING, 2015).

\subsection{Assentamento}

De acordo com Hallack (1998), as peças de concreto são assentadas, manual ou mecanicamente, sobre a camada de areia e compactadas. Em seguida, espalha-se a areia para o 
preenchimento das juntas e compactam-se as peças novamente até que as juntas estejam totalmente preenchidas com areia. Dessa forma, o intertravamento das peças, estado desejável para o bom desempenho do pavimento, é obtido. O autor ainda relata que o modelo de assentamento escolhido vai influenciar tanto na estética do pavimento como no seu desempenho. Não existe um consenso entre pesquisadores sobre a interferência do tipo de assentamento em sua durabilidade e que a propriedade de distribuição de esforços das peças intertravadas depende essencialmente de seu formato, arranjo e espessura.

Segundo Shackel (1990) e Cruz (2003), o assentamento de bloco intertravado conhecido como "espinha-de-peixe", possui melhores níveis de desempenho, apresentando menores valores de deformação permanente associados ao tráfego. Já os pavimentos tipo fileira apresentam maiores deformações permanentes, principalmente quando o assentamento for paralelo ao sentido do tráfego. Corroborando, Hallack (1998) diz que em condições de tráfego intenso, o arranjo "espinha-de-peixe" é considerado o mais adequado devido à sua boa resposta frente ao fenômeno de "escorregamento" analisado em relação ao travamento horizontal, pois os atritos entre as arestas das peças colaboram para esse travamento. A Tabela 5 apresenta os tipos de assentamento mais usuais para a colocação dos pavers.

Tabela 5 - Tipos de Assentamentos

\begin{tabular}{ccc} 
Tipo & \multicolumn{4}{c}{ Ángulo } \\
\cline { 2 - 3 } & & $\mathbf{9 0}^{\mathbf{0}}$ \\
\hline
\end{tabular}

Trama

Fileiras ("ou de corredor") vertical e horizontal, respectivamente
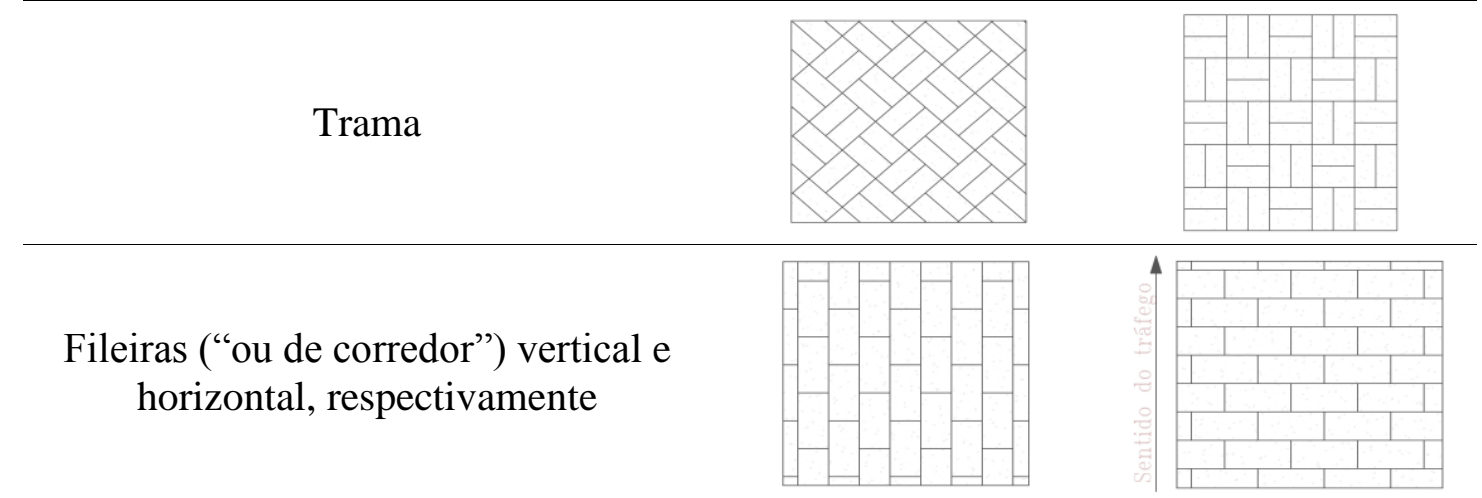

Fonte: Adaptado pela Autora (HALLACK, 1998)

De acordo com Carvalho (1998), o assentamento dos blocos intertravados deve ser realizado evitando qualquer deslocamento das peças já assentadas e irregularidades na camada 
de assentamento. A construção dos pavimentos de peças pré-moldadas de concreto se dá de acordo como ilustrado na Figura 8.

Figura 8 - Etapas da construção de pavimento intertravado

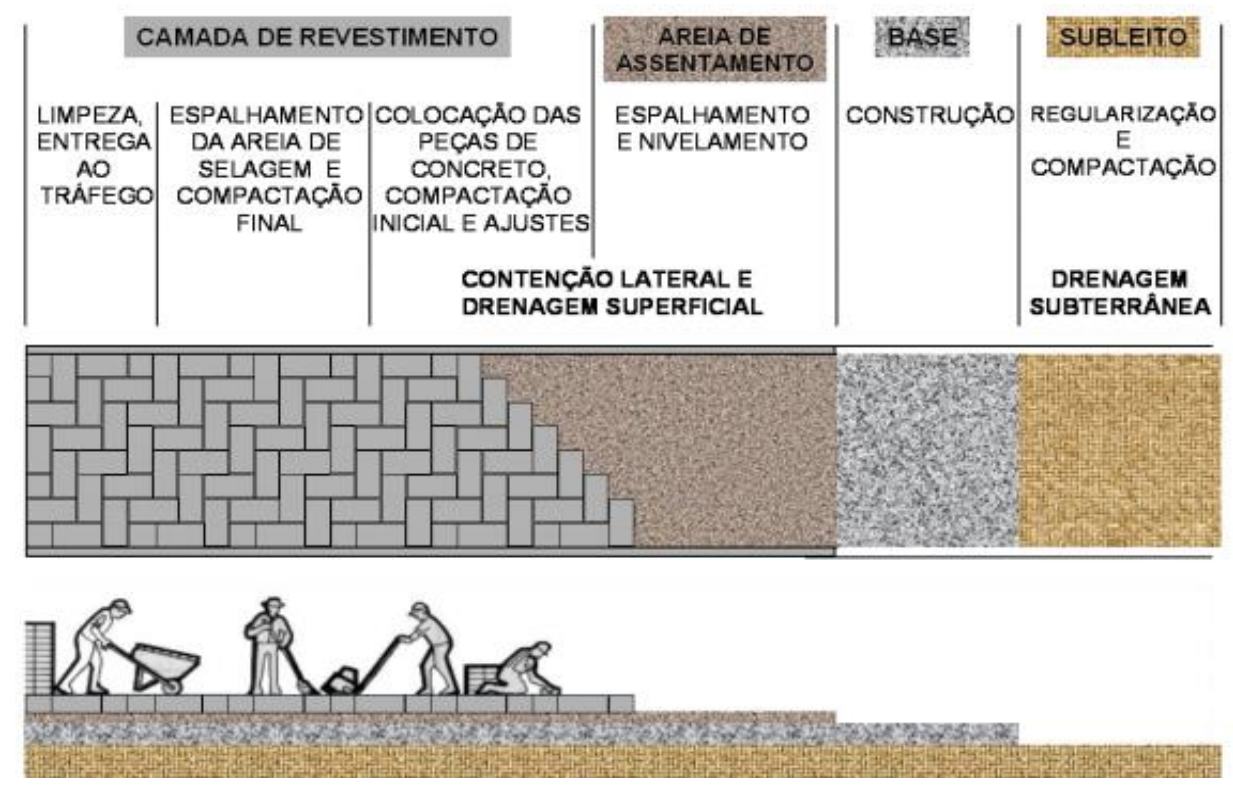

Fonte: Adaptado pela Autora (MADRID \&LONDOÑO, 1986 apud GODINHO 2009).

As etapas de construção de um pavimento intertravado apresentadas na Figura 8 são: (i) inicia-se pela regularização e compactação do subleito e do reforço do subleito; (ii) construção da base e sub-base; (iii) espalhamento e nivelamento da areia de assentamento; (iv) colocação das peças de concreto, onde, o colocador deve assentar bloco por bloco, de modo que encoste o novo bloco nos já colocados até encostá-lo na camada de assentamento; (v) assentamento das contenções laterais, travamento; (vi) espalhamento da areia de selagem e compactação sobre os blocos assentados; (vi) limpeza e liberação do trafego. O assentamento dos blocos intertravados também pode ser feito através de equipamentos automatizados. Em alguns países, essa técnica está sendo utilizada há mais tempo.

\subsection{Intertravamento}

O intertravamento é a característica principal desse tipo de pavimento que recebe esse nome pelo seu método construtivo onde as peças estão intertravadas resistindo aos movimentos de deslocamento individual, em relação às peças vizinhas. Para se obter corretamente o intertravamento, é indispensável que sejam feitas de acordo com o projeto as contenções laterais e o preenchimento das juntas com areia. Ary Junior (2007) esclarece que a 
resistência aos deslocamentos que cada bloco adquire nas direções horizontais, verticais e rotacionais em relação aos blocos vizinhos caracteriza o princípio do intertravamento do pavimento A Tabela 6 apresenta esquemas dos possíveis movimentos de deslocamentos dos pavers.

Tabela 6 - Movimentos de Deslocamentos Individuais das Peças

Movimento
Afundamento da peça, ou seja, esse intertravamento é a
capacidade que as peças adquirem de não se moverem
verticalmente em relação às vizinhas.

Fonte: Adaptado pela Autora (HALLACK,1998; ICPI, 2002; ABNT NBR 15953:2011).

\subsection{Aplicações}

O revestimento com blocos em pré-moldados de concreto amplia o espaço de sua aplicação em vários países, inclusive no Brasil como moderador do tráfego nas intervenções urbanas de Traffic Calming, como instrumento de valorização paisagística, entre outras. A aplicação é certamente uma das maiores vantagens desse tipo de pavimento em relação aos outros. Podem ser colocados em áreas que exijam uma maior resistência por haver tráfego de veículos pesados como em rodovias de alto volume, aeroportos ou portos, estacionamentos, 
pátios de cargas, calçadas, praças, passeio público e geralmente onde a estética dita às regras, favorecendo assim o seu uso.

A tecnologia de fabricação dos blocos pré-moldados em concreto desenvolveu-se bastante, atingindo alta qualidade na precisão dos tamanhos, fato que possibilita o perfeito intertravamento. As resistências podem atingir valores acima dos $40 \mathrm{MPa}$ e ter várias aplicações inclusive em rodovias, portos e aeroportos (IPCI, 2002; CRUZ, 2003; SMITH, 2003; ARY JÚNIOR, 2007). Nas Figuras 9 (a) e (b), é possível observar a aplicação do pavimento intertravado, no formato mais antigo conhecido como "tijolo" em diversas localidades.

Figura 9 - Exemplos de aplicação de pavimentos intertravados

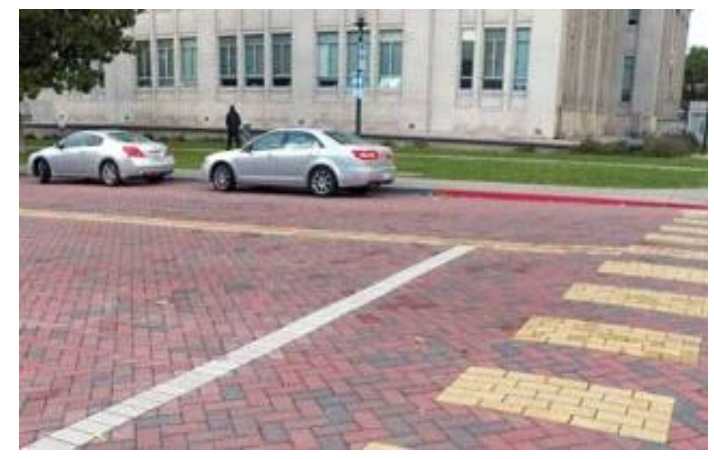

(a) llston Way em Berkeley, Califórnia Fonte: Hein, Tyson e Smith (2015).

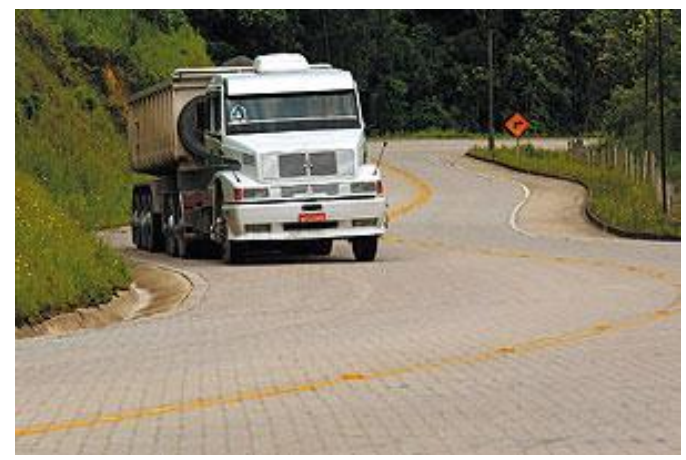

b) Rod. Industrial em Balsa Nova - PR Fonte: Farias (2011).

\subsection{Algumas Vantagens e Desvantagens}

Os blocos se destacam por suas vantagens, dentre elas estão à facilidade no assentamento, a liberação da pavimentação para o tráfego rapidamente, a acessibilidade às redes subterrâneas (redes de água, energia, telefone e saneamento) e a praticidade na manutenção (WIEBBELLING, 2015). De acordo com Fioriti (2007), um pavimento com o uso de pavers pode chegar a 25 anos de vida útil desde que todas as camadas do pavimento sejam bem executadas, os blocos tenham boa qualidade e seja realizado o assentamento correto das peças.

Segundo Wiebbelling (2015), além das diversas vantagens que esse pavimento possui, ele se destaca pela sua eficiência ambiental, pois existe a possibilidade de usar resíduos em sua composição e o bloco é semipermeável, contribuindo na drenagem urbana. Atualmente é possível encontrar uma grande diversidade de modelos, tamanhos e cores de blocos.

Segundo Ary Junior (2007), ABCP (2010) e Copel (2017), os principais benefícios da aplicação do pavimento intertravado com pavers de concreto tanto para o tráfego de pessoas como para veículos pesados são: 

a) Permeabilidade e conforto térmico;
b) Segurança: a superfície do paver é antiderrapante;
c) Durabilidade: altamente resistente ao clima e a agentes agressivos;
d) Podem ter, simultaneamente, capacidade estrutural e valor paisagístico;
e) Produto ecológico: podem ser reciclados;
f) Baixo custo de manutenção: quando se torna necessário remover determinada área pavimentada, cerca de $95 \%$ das peças retiradas podem ser reaproveitadas;
g) Possui norma técnica específica: ABNT NBR 15953:2011 e ABNT NBR 9781:2013.

Como desvantagens citam-se a baixa produtividade, a necessidade de muitos moldes, a necessidade de uma base bem reforçada, bem como um maquinário adequado e consumos de cimento elevados para atingir altas resistências solicitadas (GREGORIO, 2012).

\subsection{Resíduos Industriais}

\subsubsection{Contextualização}

A demanda pela extração de matéria-prima, seu processamento, produção, distribuição, geração de resíduos, tratamento, disposição final e elevado consumo implica no aumento dos impactos ambientais em todas as fases do sistema de produção, e tem também como consequências o acréscimo da geração de resíduos.

As atividades industriais geram diferentes tipos de resíduos, com características das mais diversas. São originados das atividades dos diferentes ramos industriais, tais como metalúrgico, geração de energia, químico, petroquímico, celulose e papel, alimentício, mineração, etc. (ABNT NBR 10004:2005; TOCCHETTO, 2009).

\subsubsection{Legislação Ambiental (definição e conceitos)}

De acordo com a Resolução do Conama no 313/2002 que dispõe sobre o Inventário Nacional de Resíduos Sólidos Industriais, a definição para resíduo sólido industrial é tudo o que resulte de atividades industriais e que se encontre nos estados sólido, semissólido, gasoso - quando contido, e líquido - cujas particularidades tornem inviável o seu lançamento na rede 
pública de esgoto ou em corpos d'água, ou exijam para isso soluções técnicas ou economicamente inviáveis em face da melhor tecnologia disponível (BRASIL, 2002).

No Brasil, de acordo com a PNRS, a destinação dos resíduos industriais é obrigação do gerador. Se o gerador é o responsável pelo tratamento e pela destinação final dos resíduos, ele pode executar esse papel por si próprio - tratamento interno - ou contratar serviços de empresas especializadas - tratamento externo. Nesse sentido, elaborou-se um conjunto de normas brasileiras relacionadas, resumidamente apresentadas na Figura 10.

Figura 10 - Normas para classificação e padronização dos resíduos sólidos.

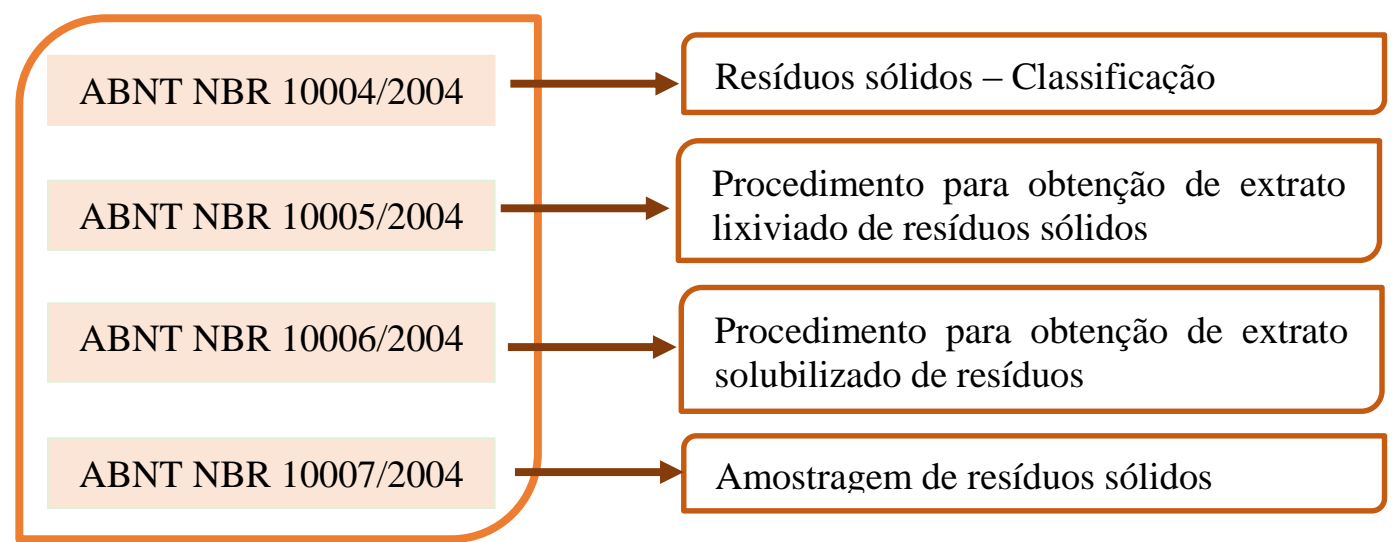

Fonte: Elaborado pela Autora (2018).

De acordo com ABNT NBR 10004:2004, na classificação dos resíduos sólidos devem ser considerados alguns aspectos como o reconhecimento do processo ou atividade que o gerou, da sua composição e características e ainda a comparação desses compostos com listagem de resíduos e substâncias no que se refere aos impactos causados ao meio ambiente e saúde para que sejam conhecidos. Dessa forma a classificação para os efeitos desta Norma, os resíduos são classificados em:

a) Resíduos Classe I - Perigosos: são os resíduos que apresentam periculosidade ou pelo menos uma das seguintes características de inflamabilidade, corrosividade, reatividade, toxicidade ou patogenicidade;

b) Resíduos Classe II - Não Perigosos: são os resíduos não perigosos e que não se enquadram na classificação de resíduos classe I e são divididos em:

- Resíduos classe II A - Não Inertes: são aqueles que não se enquadram nas classificações dos resíduos classe I ou de resíduos classe II B e podem ter propriedades como biodegradabilidade, combustibilidade ou solubilidade em água. 
- Resíduos classe II B - Inertes: são quaisquer resíduos que, quando amostrados de uma forma representativa e submetidos a um contato dinâmico e estático com água destilada ou desionizada, à temperatura ambiente não tiverem nenhum de seus constituintes solubilizados com concentrações superiores aos padrões de potabilidade de água, excetuando-se aspecto, cor, turbidez, dureza e sabor.

\subsubsection{Resíduos da Usina Termoelétrica Pecém (UTP)}

O setor de energia vem crescendo e se ampliando, com isso foram implantadas usinas termelétricas como fonte geradora de energia, assim colaborando no fornecimento de energia em todo território nacional. As usinas podem gerar um montante energético capaz de abastecer quase $85 \%$ do estado do Ceará. Os altos custos de estocagem e a limitação de área para armazenagem desses resíduos tem sido uma problemática atual e que tem desencadeado as buscas por alternativas que sejam técnicas, ambientais e economicamente viáveis para o descarte das cinzas (BARROS, 2015).

Segundo Vasconcelos (2016), existem duas células de armazenagem nessa empresa, a primeira, denominada de Módulo I, já atingiu toda sua capacidade, estando completamente preenchida com cinzas. A segunda célula, Módulo II, encontra-se parcialmente preenchida, continuando ainda a receber as cinzas provenientes da queima do carvão. Destaquese que os custos para a construção de cada um desses módulos estão em torno de 12 milhões de reais. A Figura 11 apresenta uma visão geral do complexo da UTP.

Figura 11 - Visão geral da Usina Termelétrica Pecém

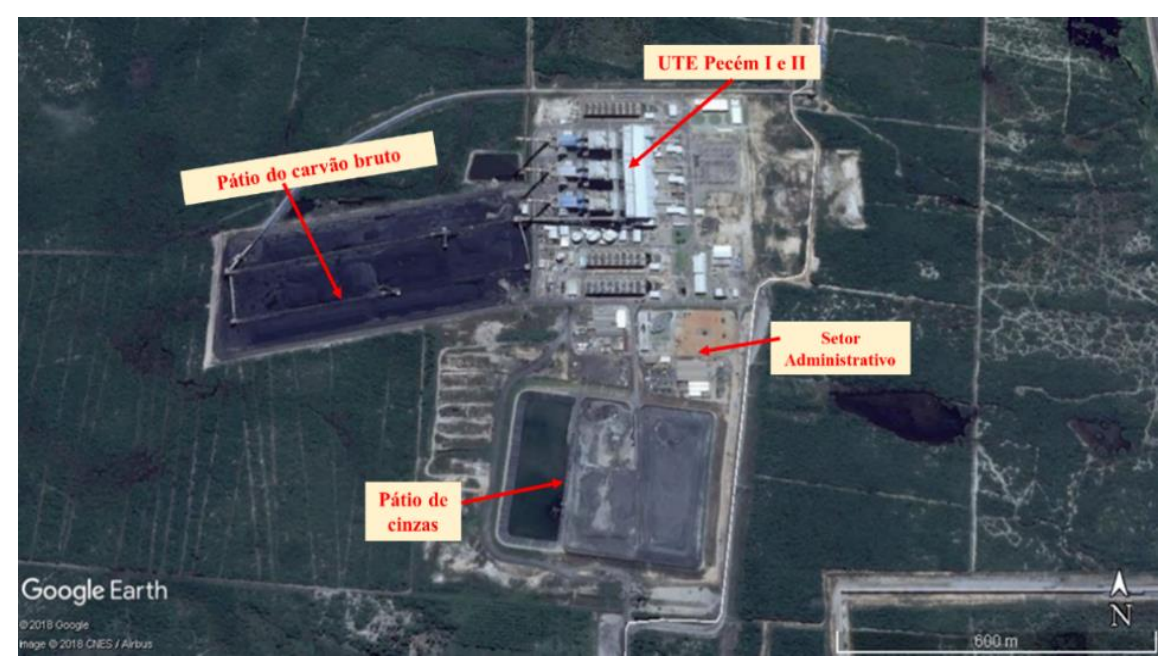

Fonte: Adaptado do Google Earth (2018). 
Atualmente UTP, opera em uma faixa de temperatura de queima do carvão na caldeira são $1.000{ }^{\circ} \mathrm{C}$ na saída dos queimadores; com intervalos de tempo entre recebimento de remessa de carvão em média de 3 navios por mês, sendo 2 para PECÉM I - PI (EDP) e 1 para PECÉM - PII (ENEVA), (informação verbal ${ }^{1}$ )

Segundo acompanhamento da UTP de janeiro a setembro de 2017, levantaram-se dados relevantes sobre o funcionamento da usina e a geração dos resíduos elencados a seguir, (informação verbal'²):

- Valor médio do poder calorifico superior encontra-se na faixa de 6092,86cal/g;

- Teor médio de cinza ficou entre $7-8,65 \%$ e teor médio de enxofre está entre $0,50-0,70$

- Consumo de carvão $\times$ geração de energia: UGI consome em média 8,58t/MW enquanto na Unidade Geradora II - UGII consome em média 9,28 t/MW;

- São produzidas nessas termelétricas 5393,26 t/mês para a UG I e UG II 8012,12 t/mês, das quais cerca de $13 \%$ correspondem às cinzas pesadas e $87 \%$ às cinzas volantes. Das cinzas volantes produzidas, $40 \%$ foram destinadas para uma cimenteira da região e $60 \%$ foram armazenadas no pátio da própria usina;

- O pátio 1 encontra-se totalmente ocupado, já o pátio 2 encontra-se ocupado com $11 \%$ de bottom ash e $89 \%$ de fly ash.

Leandro (2005) relata que a cinza leve, Figura 12 (a), por ser um material finamente dividido e apresentar boa atividade pozolânica, é empregada em vários ramos da construção civil em todo o mundo: construção de barragens e aterros rodoviários, estabilização de solos, fabricação de tijolos, telhas, artefatos de cimento (blocos estruturais, blocos de vedação e blocos para pavimentação), como aditivo em concretos, além de também ser usada como fertilizante.

No Brasil, a cinza leve é quase que totalmente utilizada na fabricação do cimento Portland pozolânico e confecção de concretos. Nos Estados Unidos, a cinza pesada, Figura 12 (b), é empregada com sucesso na construção rodoviária desde a década dos anos 50, além de ser utilizada também na fabricação de blocos de concreto, drenos de rodovias e aterros. Entretanto, no Brasil, a cinza pesada não tem tido o mesmo aproveitamento, sendo o material quase que totalmente descartado a céu aberto nas bacias de sedimentação, constituindo riscos ambientais (LEANDRO, 2005).

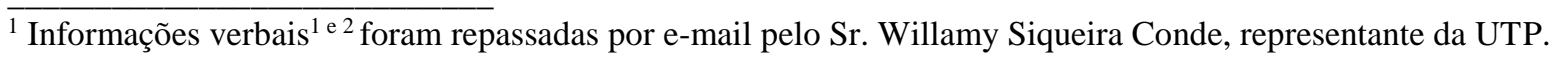


Figura 12 - Aspectos da cinza leve (à esquerda) e cinza pesada (à direita)

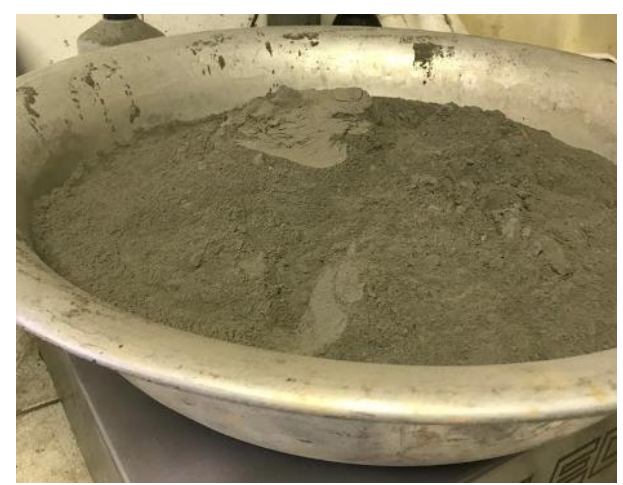

(a) Cinza leve ou fly ash

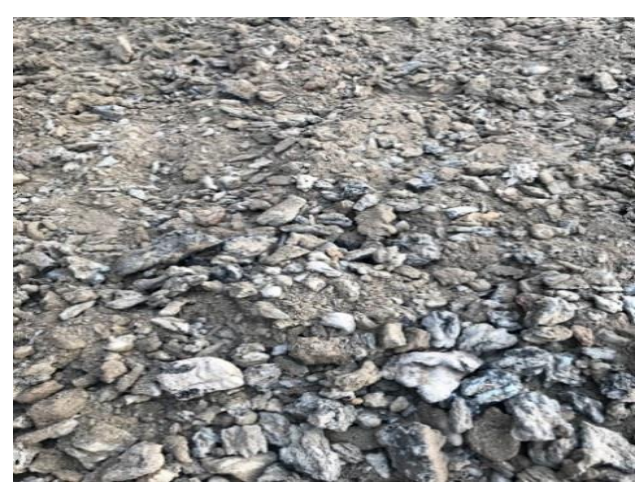

(b) Cinza pesada ou bottm ash

Fonte: Autora (2017).

Uma alternativa para o problema de geração de resíduos seria a sua reutilização ou reciclagem, que possibilita a conservação de recursos naturais e permite uma economia de energia, sobretudo na área de construção civil, uma vez que é um dos setores que mais consome recursos naturais. Diante deste panorama, vê-se necessário e importante pensar em alternativas para utilizar esses resíduos, incorporando-o, por exemplo, em processos de fabricação de pavimentos intertravados, por exemplo.

\subsection{Considerações finais}

Neste Capítulo foi realizada uma revisão bibliográfica voltada para pavimentos intertravados, cinzas de termoelétrica, bem como uma abordagem mais prática acerca dos procedimentos e normas para o emprego dos BCPI. No Capítulo 3, que se segue, serão apresentados os materiais utilizados e os métodos definidos para o programa experimental da pesquisa. 


\section{MATERIAIS E MÉTODOS}

No presente capítulo serão detalhados os passos necessários para alcançar os objetivos previamente propostos pela pesquisa no Capítulo 1. Para tanto, dividiu-se o estudo em Revisão Bibliográfica, contemplada no Capítulo 2, Seleção dos Materiais e Métodos juntamente com o Programa Experimental da pesquisa, abordados no presente Capítulo.

\subsection{Materiais}

Para elaboração do presente trabalho foram usados os materiais descritos na Tabela 7 que apresenta a nomenclatura para identificá-los.

Tabela 7 - Nomenclatura Usada para Identificar os Materiais Usados na Pesquisa

\begin{tabular}{cc}
\hline Materiais & Nomenclatura Adotada \\
\hline Agregado Graúdo Natural & AGN \\
Agregado Miúdo Natural & AMN \\
Agregado Graúdo - Cinza Pesada & AGCP \\
Agregado Miúdo - Cinza Pesada (beneficiada) & AMCP \\
Cinza Pesada (in natura) & CPIN \\
Aglomerante - Cimento & CIME \\
Areia Natural & ARN \\
Aditivo & ADIT \\
\hline
\end{tabular}

Fonte: Elaborado pela Autora (2018).

\subsubsection{Agregados naturais}

Os agregados naturais utilizados no presente estudo foram coletados diretamente por um caminhão na pedreira situada na Região Metropolitana de Fortaleza (RMF), no município do Eusébio, localizada a uma distância de aproximadamente $26 \mathrm{~km}$ da cidade de Fortaleza, conforme visualizado na Figura 13. 
Figura 13 - Localização da pedreira em relação ao Campus do PICI

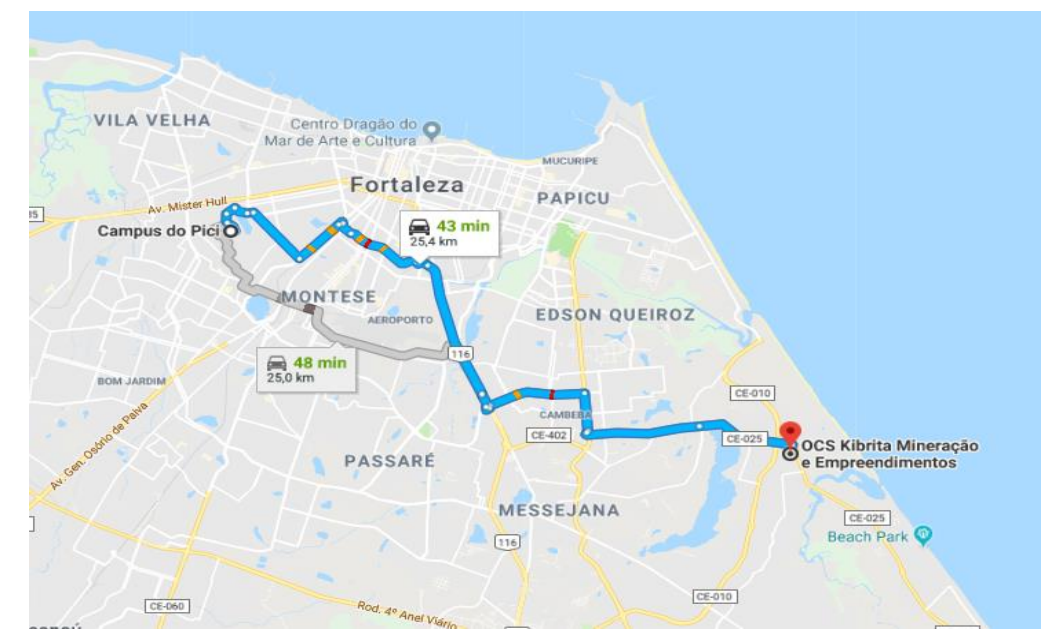

Fonte: Google Maps (2018).

O volume de material coletado foi aproximadamente de $15 \mathrm{~m}^{3}$, sendo distribuídos da seguinte forma: $3 \mathrm{~m}^{3}$ de brita $19 \mathrm{~mm} ; 3 \mathrm{~m}^{3}$ de brita $12,5 \mathrm{~mm} ; 6 \mathrm{~m}^{3}$ de "pó de brita" de diâmetro inferior a $4,75 \mathrm{~mm}$ e $3 \mathrm{~m}^{3}$ de areia natural. O destino final dos materiais foi o Campus do PICI - UFC onde ficaram armazenados em baias, separadamente, ilustrado na Figura 14.

Figura 14 - Armazenamento dos AN

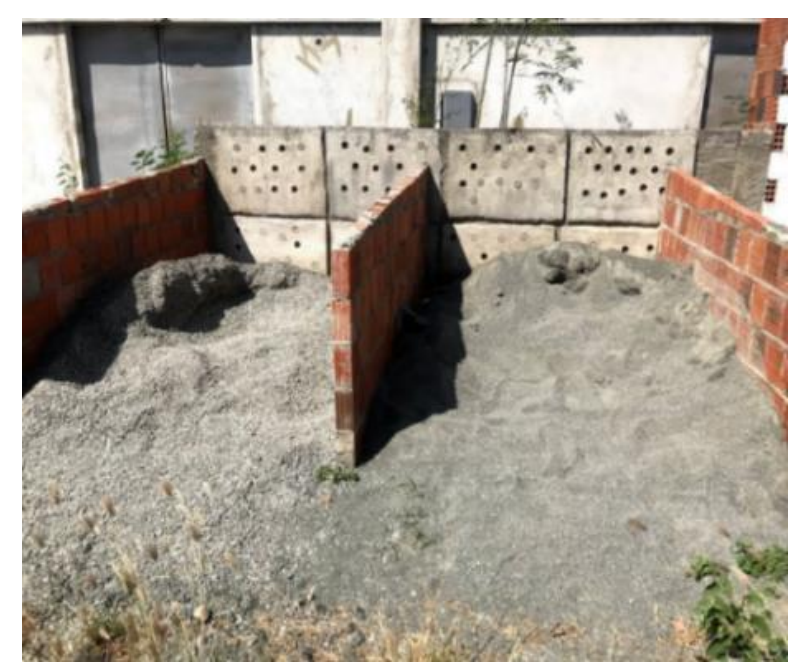

Fonte: Autora (2018).

\subsubsection{Cinza Pesada ou Bottom Ash}

A cinza pesada utilizada na presente pesquisa também foi coletada diretamente por um caminhão, na UTP situada no Complexo Industrial e Portuário do Pecém (CIPP), localizada 
no município de São Gonçalo do Amarante na RMF, à aproximadamente $50 \mathrm{~km}$ da cidade de Fortaleza, conforme visualizado na Figura 15.

Figura 15 - Localização da UTP em relação ao Campus do PICI

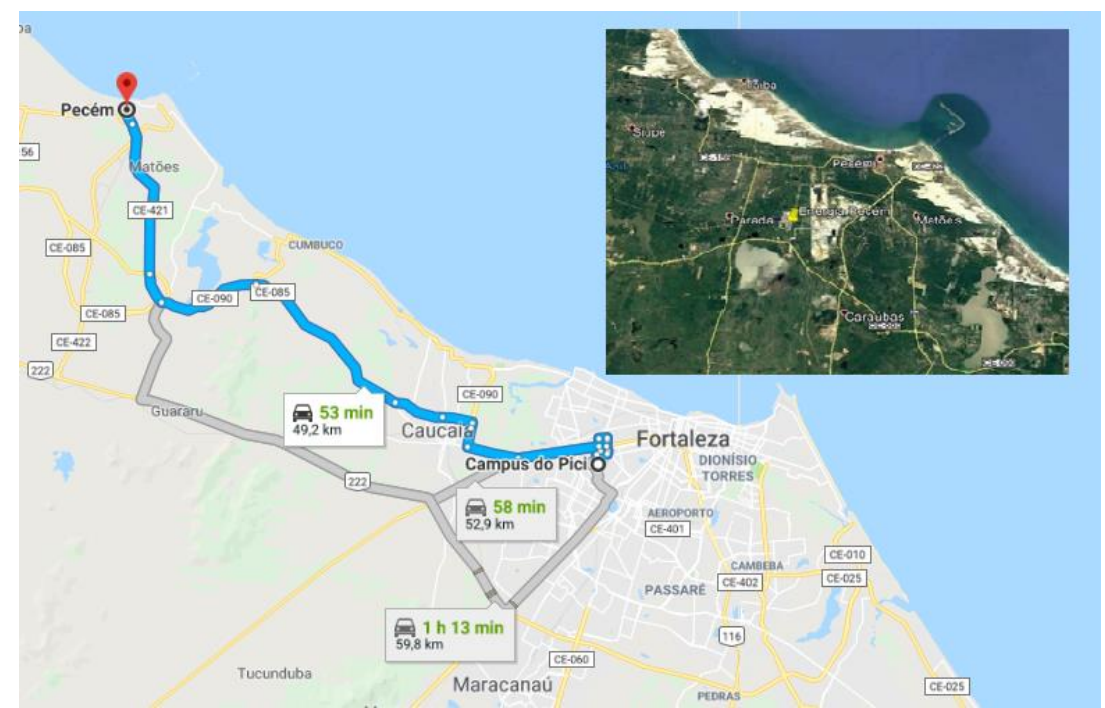

Fonte: Google Maps e Google Earth (2018).

Para o presente estudo foram coletadas e transportadas aproximadamente 6 ton. de cinza. O material foi depositado no estacionamento da UFC, Figura 16 (a), devido à necessidade de espaço para homogeneização. O piso do estacionamento foi previamente limpo e coberto, conforme apresentado na Figura 16 (b) a fim de evitar a contaminação da amostra.

Figura 16 - Transporte e disposição da cinza pesada no pátio do estacionamento da UFC

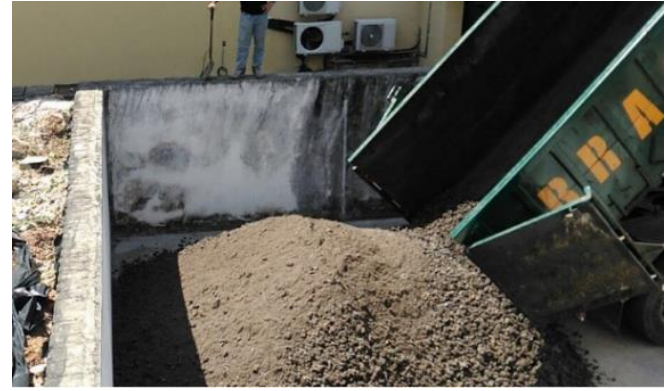

(a) Caminhão destinado à coleta depositando a cinza no pátio da UFC Fonte: Autora (2017)

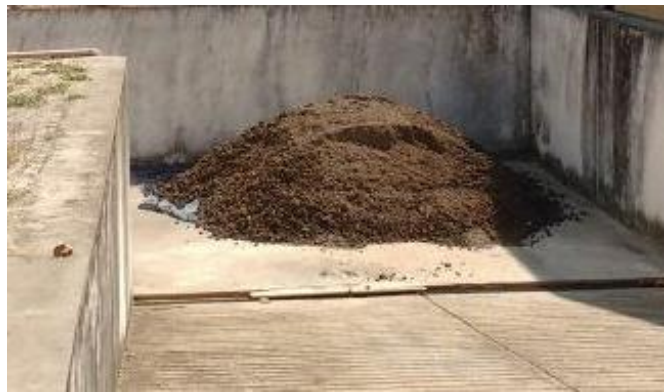

(b) Disposição da cinza no pátio da UFC

Em seguida, iniciou-se o processo de quarteamento do material, Figura 17 (a), visando obter amostras representativas. Posteriormente, fez-se o acondicionamento das cinzas em sacos de "ráfia" onde em cada saco foi depositada uma pá de material pertencente a cada 
lote de divisão do quarteamento. Uma vez ensacada, a cinza foi transportada e armazenada em local protegido de intempéries, conforme Figura 17 (b).

Figura 17 - Quarteametno e destinação adequada da cinza.

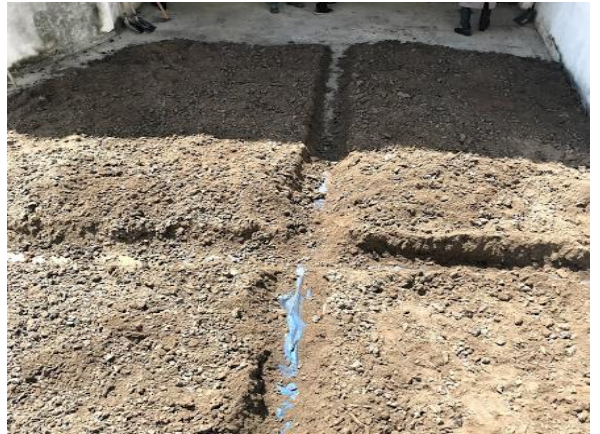

(a) Quarteamento

Fonte: Autora (2017).

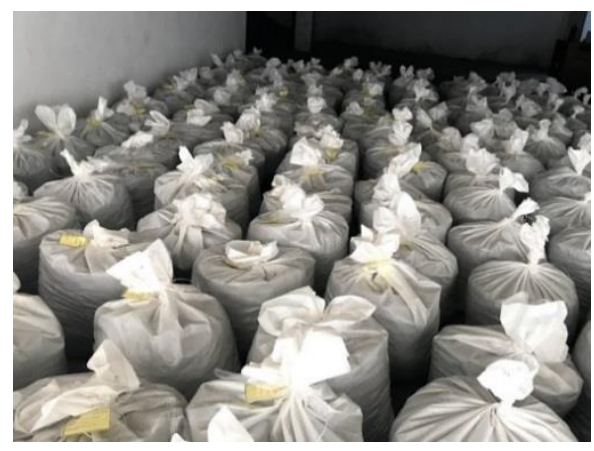

(b) Armazenamento

\subsubsection{Aglomerante (cimento Porthand)}

Fernandes (2016) recomenda que para a fabricação dos Pavers, em razão da necessidade do manuseio (desforma) de forma rápida, ou seja, no mesmo momento ou no dia seguinte, são mais indicados o uso de cimentos dos tipos $\mathrm{CP}-\mathrm{II}-\mathrm{Z}$ ou $\mathrm{CP}-\mathrm{V}$ - ARI por apresentarem maior resistência nas primeiras idades.

O cimento Portland utilizado no estudo foi do tipo CP-V - ARI, sendo doado pela empresa Cimento Apodi localizada na RMF. Os 15 sacos de cimento foram transportados da fábrica até a UFC, ficando armazenados sobre paletes e cobertos com lona em um galpão fechado, protegido de intempéries.

\subsubsection{Aditivo e Água}

As especificações do aditivo utilizadas foram disponibilizadas pela Empresa que cedeu os materiais de pesquisa, por isso, apenas tomaram-se como referência os dados informados por ela, como por exemplo a massa específica do aditivo $=1,012 \mathrm{~g} / \mathrm{cm}^{3}$. Esse aditivo é usado para fins industriais e tem função plastificante e densificador de concreto, isento de cloretos. Assemelha-se com as especificações do aditivo hagen bloco R.

A água utilizada na pesquisa foi oriunda do sistema de abastecimento da UFC Campus do PICI. 


\subsection{O Programa Experimental}

Na perspectiva de atingir os objetivos pré-estabelecidos nesta pesquisa, adotou-se uma sequência metodológica composta de 3 etapas, conforme mostrado na Figura 18.

Figura 18 - Fluxograma resumido das etapas metodológicas.

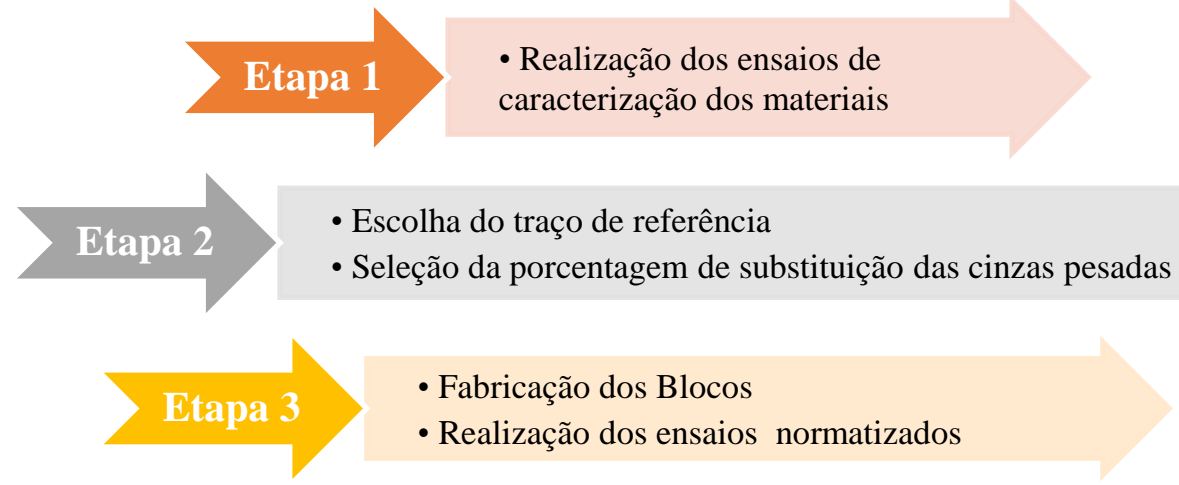

Fonte: Elaborado pela Autora (2018).

\subsubsection{Etapa 1 - Ensaios de caracterização dos materiais}

Baseado na literatura e com a finalidade de agilizar os ensaios e facilitar o entendimento dos resultados, dividiram-se os ensaios em: caracterização dos agregados graúdos (naturais e cinza pesada), caracterização dos agregados miúdos (natural e cinza pesada) e caracterização da areia natural. Na Figura 19 são apresentados os ensaios realizados e as normas vigentes, bem como os materiais ensaiados. 
Figura 19 - Fluxograma experimental da Etapa 1

\begin{tabular}{|c|c|}
\hline \multirow{16}{*}{$\begin{array}{l}\text { Agregados graúdos } \\
\text { (naturais e cinza pesada) }\end{array}$} & Determinação da composição granulométrica - ABNT NBR NM 248 :2003 \\
\hline & Massa específica $\left(\mathrm{g} / \mathrm{cm}^{3}\right)$ - ABNT NBR NM 53:2009 \\
\hline & Absorção de água (\%) - ABNT NBR NM 53:2009 \\
\hline & Material pulverulento (\%) - ABNT NBR NM 46:2003 \\
\hline & Massa unitária solta $\left(\mathrm{kg} / \mathrm{m}^{3}\right)$ - aprox. $10 \mathrm{~m}^{3}$ - ABNT NBR NM 45:2006 \\
\hline & Índice de desgaste por abrasão "Los Angeles" - ABNT NBR NM 51:2001 \\
\hline & Reatividade álcali-agregado - ABNT NBR 15577-4:2009 \\
\hline & Cloretos - ABNT NBR 9917:2009 \\
\hline & Sais Solúveis - ABNT NBR 9917:2009 \\
\hline & Sulfatos - ABNT NBR 9917:2009 \\
\hline & Angularidade (AIMS) \\
\hline & Textura Superficial (AIMS) \\
\hline & Forma 2D (AIMS) \\
\hline & Esfericidade (AIMS) \\
\hline & Lixiviação (extrato lixiviado) - ABNT NBR 10005:2004 \\
\hline & Solubilização (extrato solubilizado) - ABNT NBR 10006: 2004 \\
\hline & Determinação da composição granulométrica - ABNT NBR NM 248 :2003 \\
\hline & Massa específica $\left(\mathrm{g} / \mathrm{cm}^{3}\right)$ - ABNT NBR NM 52:2009 \\
\hline & Absorção de água (\%) - ABNT NBR NM 30:2001 \\
\hline & Material pulverulento (\%) - ABNT NBR NM 46:2003 \\
\hline & Massa unitária solta $\left(\mathrm{kg} / \mathrm{m}^{3}\right)$ - aprox. $10 \mathrm{~m}^{3}$ - ABNT NBR NM 45:2006 \\
\hline Agregados miudos & Reatividade álcali-agregado - ABNT NBR 15577-4:2009 \\
\hline (naturais e cinza pesada) & Cloretos - ABNT NBR 9917:2009 \\
\hline & Sais Solúveis - ABNT NBR 9917:2009 \\
\hline & Sulfatos - ABNT NBR 9917:2009 \\
\hline & Angularidade (AIMS) \\
\hline & Forma 2D (AIMS) \\
\hline & Lixiviação (extrato lixiviado) - ABNT NBR 10005:2004 \\
\hline & Solubilização (extrato solubilizado) - ABNT NBR 10006: 2004 \\
\hline & Determinação da composição granulométrica - ABNT NBR NM 248 :2003 \\
\hline Areia Natural & Massa específica $\left(\mathrm{g} / \mathrm{cm}^{3}\right)$ - ABNT NBR NM 52:2009 \\
\hline Reta Maturat & Absorção de água (\%) - ABNT NBR NM 30:2001 \\
\hline & Material pulverulento (\%) - ABNT NBR NM 46:2003 \\
\hline & Massa unitária solta $\left(\mathrm{kg} / \mathrm{m}^{3}\right)$ - aprox. $10 \mathrm{~m}^{3}$ - ABNT NBR NM 45:2006 \\
\hline Cimento e Aditivo & Fabricante \\
\hline
\end{tabular}

Fonte: Elaborado pela Autora (2018).

Algumas observações e adaptações nos métodos de ensaios na caracterização dos materiais da pesquisa foram necessárias para alcançar os resultados obtidos, descritos a seguir. Todas as amostras foram preparadas de acordo com as exigências normativas para cada ensaio. A partir do peneiramento realizado, obteve-se a dimensão máxima característica (Dmáx) associada à distribuição granulométrica do agregado. Determinou-se o Módulo de Finura (MF), com aproximação de 0,01. Considerou-se para o ensaio a amostra de (CPIN). Para 
os agregados naturais, o Dmáx de cada um deles e o módulo de finura foi equivalente para a brita $19 \mathrm{~mm}$; brita $12,5 \mathrm{~mm}$, brita $4,75 \mathrm{~mm}$ e areia natural.

No ensaio de granulometria, a cinza pesada foi separada em duas frações por meio de um corte na peneira de abertura \#4,75 mm, sendo considerado como agregado graúdo o que ficou retido nessa e agregado miúdo o que passou. Todos os procedimentos normativos foram seguidos igualmente para os agregados naturais e para cinza pesada.

Ressalva importante é que uma das etapas do processo de obtenção da massa específica de um agregado graúdo é deixá-lo submerso em água por 24 horas. Entretanto, percebeu-se que parcela da parte graúda da cinza pesada flutuou, conforme observado na Figura 20 (a), sendo, portanto, um material aparentemente de densidade menor do que a água. Assim, para a obtenção do resultado, foi necessário realizar uma adaptação do ensaio: despejou-se a cinza em um saco de nylon vazado, Figura 20 (b), amarrando-se a boca e colocando um peso sobre o mesmo, Figura 20 (c), e posteriormente foram subtraídos os pesos nos cálculos do ensaio.

Figura 20 - Adaptação do ensaio de massa específica para o caso da cinza pesada.

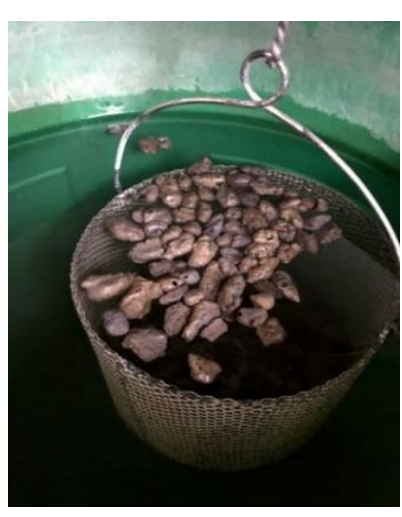

(a) Cinza flutuando

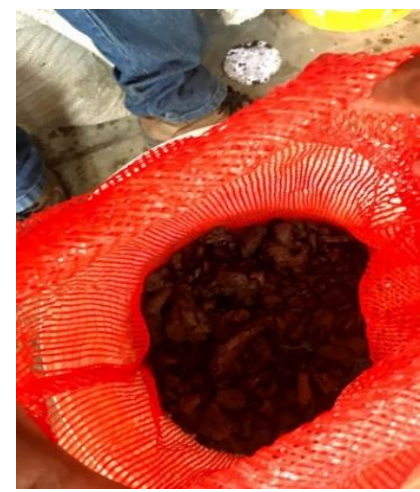

(b) saco de nylon vasado

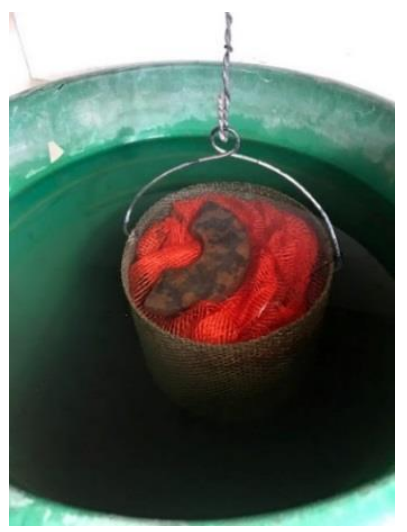

(c) $\operatorname{cinza}+$ saco+ peso

Fonte: Autora (2018).

Na obtenção de imagens, com o uso do Processamento Digital de Imagens (PDI) procedeu-se de acordo com Bessa (2012) e Ibiapina (2018), que utilizaram o Aggregate Image Measurement System (AIMS), Figura 21, que se caracteriza em um sistema simples, que consiste em uma câmera e dois diferentes tipos de iluminação para capturar imagens de agregados em diferentes resoluções, das quais as propriedades de forma são avaliadas usando técnicas de análise de imagens. Resumidamente, quando o ensaio é iniciado, a bandeja contendo os agregados começa a girar dentro do equipamento, e a imagem de cada partícula é capturada; em seguida, a bandeja gira novamente para que a altura dos agregados seja obtida e, assim, 
todas as dimensões incluindo a profundidade, sejam adquiridas; uma terceira digitalização é feita para que os níveis de textura sejam obtidos.

Figura 21 - Aggregate Image Measurement System (AIMS)

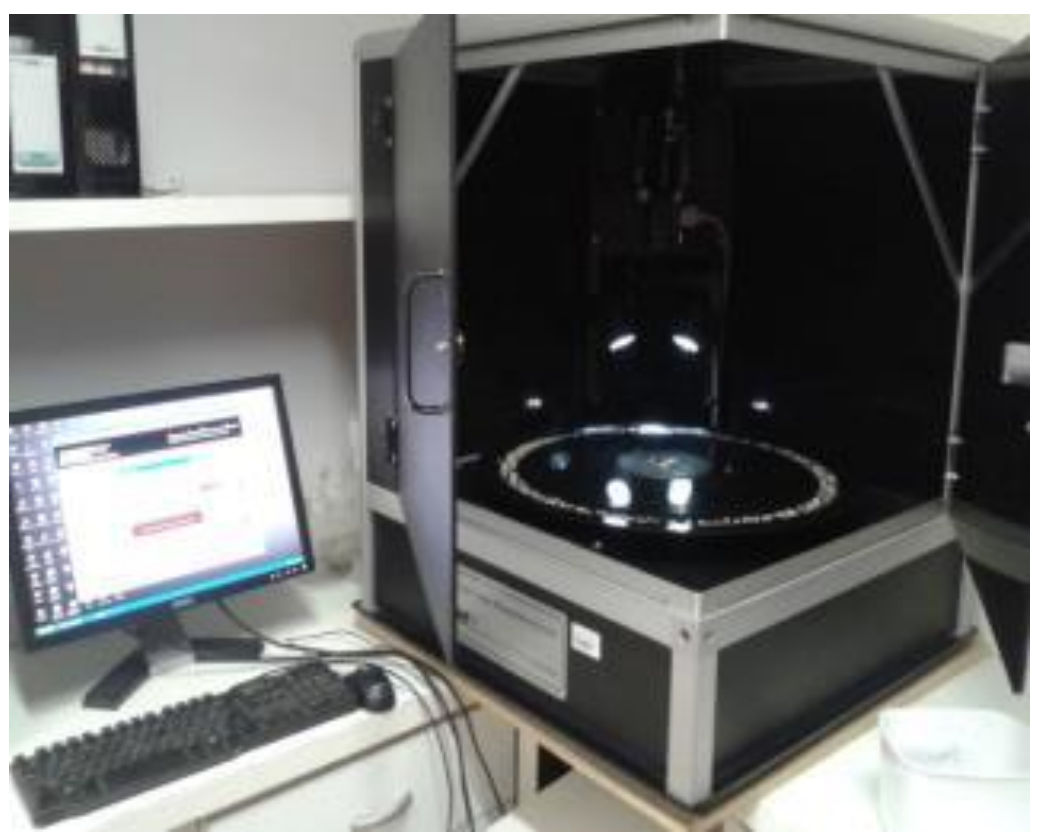

Fonte: Autora (2018),

Ibiapina (2018), propôs um sistema de classificação das propriedades de forma de agregados, caracterizados com o uso do AIMS, o que contribui para a adequada seleção de materiais brasileiros, onde, considerou a classificação de Al Rousan, conforme Tabela 8.

Tabela 8 - Classificação das Propriedades de Forma dos Agregados Através do Uso do AIMS

\begin{tabular}{|c|c|c|c|c|c|}
\hline Propriedade & \multicolumn{5}{|c|}{ Valores-limite/ Classificação } \\
\hline \multirow{2}{*}{$\begin{array}{l}\text { Forma 2D } \\
\text { (miúdo) }\end{array}$} & $<6,5$ & $6,5-8,0$ & $8,0-10,5$ & $>10,5$ & - \\
\hline & Circular & Semicircular & Semialongado & Alongado & - \\
\hline \multirow{3}{*}{$\begin{array}{l}\text { Esfericidade } \\
\text { (graúdo) }\end{array}$} & $<0,6$ & $0,6-0,7$ & $0,7-0,8$ & $>0,8$ & - \\
\hline & Achatado/ & Baixa & Esfericidade & Alta & - \\
\hline & Alongado & esfericidade & moderada & esfericidade & - \\
\hline \multirow{2}{*}{$\begin{array}{l}\text { Angularidade } \\
\text { (miúdo e graúdo) }\end{array}$} & $<2100$ & $2100-4000$ & $4000-5400$ & $>5400$ & - \\
\hline & Arredondado & Subarredondado & Subangular & Angular & - \\
\hline \multirow[b]{2}{*}{$\begin{array}{l}\text { Textura superficial } \\
\text { (graúdo) }\end{array}$} & $<165$ & $165-275$ & $275-350$ & $350-460$ & $>460$ \\
\hline & Polido & Macio & $\begin{array}{l}\text { Baixa } \\
\text { rugosidade }\end{array}$ & $\begin{array}{l}\text { Rugosidade } \\
\text { moderada }\end{array}$ & $\begin{array}{l}\text { Alta } \\
\text { rugosidade }\end{array}$ \\
\hline
\end{tabular}

Fonte: Adaptado de Al Rousan (2004). 
Os ensaios de caracterização em relação ao cimento, CPV-ARI, não foram realizados, apenas tomou-se como referência os dados disponibilizados pela empresa apresentados na Tabela 9.

Tabela 9 - Dados da Caracterização do Cimento

\begin{tabular}{|c|c|c|c|}
\hline Ensaio & Método de Ensaio & Resultados & $\begin{array}{l}\text { Requisitos NBR } 16697 \\
\text { (ABNT, 2019C) }\end{array}$ \\
\hline Área específica (Blaine) & $\begin{array}{c}\text { NBR } 16372 \\
(\text { ABNT, 2015c) }\end{array}$ & $4198 \mathrm{~cm}^{2} / \mathrm{g}$ & - \\
\hline Massa específica & $\begin{array}{c}\text { NBR NM } 23 \\
(\text { ABNT, 2001a) }\end{array}$ & $3,06 \mathrm{~g} / \mathrm{cm}^{3}$ & - \\
\hline $\begin{array}{l}\text { Finura - Resíduo na } \\
\text { Peneira } \# 0,075 \mathrm{~mm}\end{array}$ & $\begin{array}{c}\text { NBR } 11579 \\
(\mathrm{ABNT}, 2013)\end{array}$ & $0,2 \%$ & $\leq 6,0 \%$ \\
\hline $\begin{array}{l}\text { Finura - Resíduo na } \\
\text { Peneira \#0,032mm }\end{array}$ & $\begin{array}{c}\text { NBR } 12826 \\
(\text { ABNT, 2014c) }\end{array}$ & $4,8 \%$ & - \\
\hline Água de consistência & $\begin{array}{c}\text { NBR } 16606(\text { ABNT, } \\
2017 \mathrm{a})\end{array}$ & $28,5 \%$ & - \\
\hline Início de pega & $\begin{array}{c}\text { NBR } 16607 \text { (ABNT, } \\
2017 b)\end{array}$ & $2 \mathrm{~h} 45 \mathrm{~min}$ & $\geq 1 \mathrm{~h}$ \\
\hline Fim de pega & $\begin{array}{c}\text { NBR } 16607 \text { (ABNT, } \\
2017 b)\end{array}$ & $3 \mathrm{~h} 45 \mathrm{~min}$ & $\leq 10 \mathrm{~h}$ \\
\hline $\begin{array}{l}\text { Expansibilidade de Le } \\
\text { Chatelier - a quente }\end{array}$ & $\begin{array}{c}\text { NBR } 11582(A B N T, \\
2016 b)\end{array}$ & $0,00 \mathrm{~mm}$ & $\leq 5 \mathrm{~mm}$ \\
\hline Perda ao fogo & $\begin{array}{c}\text { NBR NM } 18 \\
(\mathrm{ABNT}, 2012 \mathrm{a})\end{array}$ & $4,39 \%$ & $\leq 6,5 \%$ \\
\hline $\begin{array}{c}\text { Óxido de Magnésio - } \\
\text { MgO }\end{array}$ & $\begin{array}{l}\text { NBR NM } 11-2 \\
(\text { ABNT, 2012b) }\end{array}$ & $4,17 \%$ & $\leq 6,5 \%$ \\
\hline $\begin{array}{l}\text { Anidrido Sulfúrico - } \\
\qquad \text { SO3 }\end{array}$ & $\begin{array}{l}\text { NBR NM } 16 \\
(\text { ABNT, 2012c) }\end{array}$ & $3,24 \%$ & $\leq 4,5 \%$ \\
\hline Resíduo insolúvel & $\begin{array}{l}\text { NBR NM 15 } \\
(\text { ABNT, 2012d) }\end{array}$ & $0,69 \%$ & $\leq 3,5 \%$ \\
\hline $\begin{array}{l}\text { Anidrido carbônico - } \\
\qquad \mathrm{CO} 2\end{array}$ & $\begin{array}{l}\text { NBR NM } 20 \\
(\text { ABNT, 2012e) }\end{array}$ & $2,97 \%$ & $\leq 5,5 \%$ \\
\hline \multirow{4}{*}{$\begin{array}{l}\text { Resistência } \\
\text { à } \\
\text { Compressão }\end{array}$} & \multirow{4}{*}{$\begin{array}{c}\text { NBR } 7215 \text { (ABNT, } \\
1997)\end{array}$} & $25,9 \mathrm{MPa}$ & $\geq 14,0 \mathrm{MPa}$ \\
\hline & & $36,6 \mathrm{MPa}$ & $\geq 24,0 \mathrm{MPa}$ \\
\hline & & $44,3 \mathrm{MPa}$ & $\geq 34,0 \mathrm{MPa}$ \\
\hline & & $53,2 \mathrm{MPa}$ & - \\
\hline
\end{tabular}




\subsubsection{Etapa 2-Escolhas dos Traços}

Para a definição dos traços primeiramente ocorreu a escolha do Traço de Referência (TR), onde optou-se pela reprodução de um traço comercial empregado na produção de blocos de concreto intertravados cedido por uma Empresa localizada na RMF. Segundo informações por parte da referida empresa esse TR foi dosado pelo método da ABCP, onde utilizou-se a caracterização dos agregados naturais citados no item 3.2.1 (informação verbal ${ }^{3}$ ).

O traço comercial ou TR, utilizado neste estudo tem a relação de 1:6, sendo, 1:0,9:3,9:1,2 respectivamente, CIMENTO:ARN:AMN:AGN+ 7\% água (em relação aos agregados) e 0,04 \% de aditivo (em relação à massa total). Para melhor compreensão, o traço foi detalhado na Tabela 10.

Tabela 10 - Consumo de Materiais em kg de Concreto no TR (para $1 \mathrm{~m}^{3}$ )

\begin{tabular}{cc}
\hline Materiais & Consumo (kg) \\
\hline CIMENTO & 142,86 \\
ARN & 128,57 \\
AMN & 557,14 \\
AGN & 171,43 \\
ÁGUA & 60,00 \\
ADITIVO & 0,11 \\
\hline
\end{tabular}

Fonte: Elaborado pela Autora (2018).

Definido o TR, foram propostas quais seriam as porcentagens de substituição dos agregados naturais por cinza pesada utilizando o mesmo procedimento de dosagem do traço de referência. Ressalte-se que nesta fase do estudo foram consideradas as informações contidas na literatura e na caracterização dos materiais, na trabalhabilidade do concreto, no processo de moldagem e desmoldagem dos blocos e no fator água/cimento.

No tocante à escolha de qual fração substituir, considerou-se as curvas granulométricas, dos materiais. Pois, a distribuição granulométrica da cinza pesada, não permitiu a sua aplicação conforme coletada da usina. Sendo assim, os resultados desta pesquisa são limitados ao seu beneficiamento, feito por meio da aproximação da curva granulométrica da cinza pesada e do agregado miúdo convencional substituído parcialmente. Sendo assim, decidiu-se fracionar toda a cinza pesada coletada em AGCP e AMCP, nomeadas conforme nomenclatura apresentada na Tabela 7.

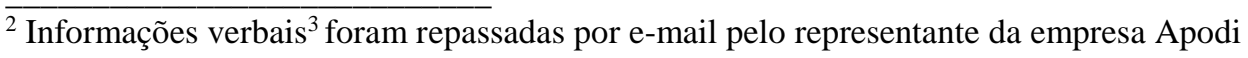


Analisou-se os resultados dos demais ensaios de caracterização, explicados na Etapa 1. Optou-se por fixar apenas a variável de substituição dos agregados sem modificar a composição água/cimento do TR, apenas a troca dos agregados miúdos, ficando assim os demais componentes do concreto iguais.

Vale ressaltar que as substituições foram em massa compensando a massa específica, promovendo, então, uma substituição em volume, sendo calculado consideram a massa dos materiais, pois em laboratório facilitaria a obtenção dos resultados. Utilizou-se a Equação 1 para o cálculo da substituição em massa.

$$
\mathrm{M}_{\mathrm{as}}=\frac{\gamma_{\mathrm{AMCP}}}{\gamma_{\mathrm{AMN}}} \times \mathrm{P}_{\mathrm{AMN} / \mathrm{TR}} \times \%_{\mathrm{SUB}}
$$

Onde:

$\mathrm{M}_{\mathrm{as}}$ - massa de cinza a substituir, em kg;

$\gamma_{\mathrm{AMCP}}$ - valor da massa específica da AMCP, em kg;

$\gamma_{\mathrm{AMn}}$ - valor da massa específica da AMN, em kg;

$\mathrm{P}_{\mathrm{AMN} / \mathrm{TR}}$ - peso do AMN do TR (peso da quantidade de agregado miúdo natural do traço de referência), em $\mathrm{kg}$;

\% sUB - valor da porcentagem que se pretende substituir em relação ao traço de referência, em kg.

As possíveis porcentagens de substituição verificadas foram: T10, T20, T30, T40 e T50 (onde T significa traço e o número ao lado corresponde a porcentagem de cinza substituída no TR) da quantidade de AMN por AMCP para fabricação dos blocos, baseados em resultados empíricos realizados da seguinte forma:

- Na primeira amostra foi separado aproximadamente 3 litros do TR para servir de comparativo, como mistura;

- Na segunda amostra foi TR menos 10\% de AMN substituído por 10\% do AMCP, não havendo dificuldade de mistura;

- Na terceira amostra de TR menos 20\% de AMN substituído por 20\% do AMCP, não havendo dificuldade de mistura;

- Na quarta amostra de TR menos 30\% de AMN substituído por 30\% do AMCP, não havendo dificuldade de mistura;

- Na quinta amostra de TR menos 40\% de AMN substituído por 40\% do AMCP, apresentou pequena dificuldade de mistura; 
- Na sexta amostra de TR menos 50\% de AMN substituído por 50\% do AMCP, houve dificuldade de mistura, no entanto conseguisse realizar o teste;

- Na sétima amostra de TR menos 60\% de AMN substituído por 60\% do AMCP, não teve possibilidade de mistura, no qual se fazia necessário a mudança no fator a/c, que não foi realizado pois não era objetivo da pesquisa em questão, que apenas optou-se pela mudança dos agregados miúdos.

\subsubsection{Etapa 3 - Fabricação dos Blocos e Realização dos Ensaios Normatizados}

Para a fabricação dos blocos todos os materiais foram secos em estufa e a cinza pesada foi separada nas mesmas curvas granulométrica dos AMN e AMCP. Em seguida, procedeu-se a determinação do peso dos materiais para a confecção do TR e demais traços $(\mathrm{AGN}+\mathrm{AMN}+\mathrm{CIME}+\mathrm{A} G U \mathrm{~A}+\mathrm{ADITIVO}$ diluído na água + \%AMCP). Para isto, foram necessários: (i) baldes de plástico limpo para armazenar os agregados e transportar o concreto fabricado; (ii) betoneira (iii) vibroprensa e (iv) pessoal com experiência para operar os equipamentos.

A máquina de Vibroprensa fabricada pela Empresa Tprex que se utilizou na pesquisa é operada manualmente, por acionamento hidráulico. A capacidade do cilindro hidráulico da referida máquina é de 4 toneladas e o motor responsável pela vibração tem $10 \mathrm{cv}$ de potência, ilustrado na Figura 22. O processo de fabricação está detalhado no Apêndice A.

Figura 22 - Máquina de Vibroprensa Tprex.

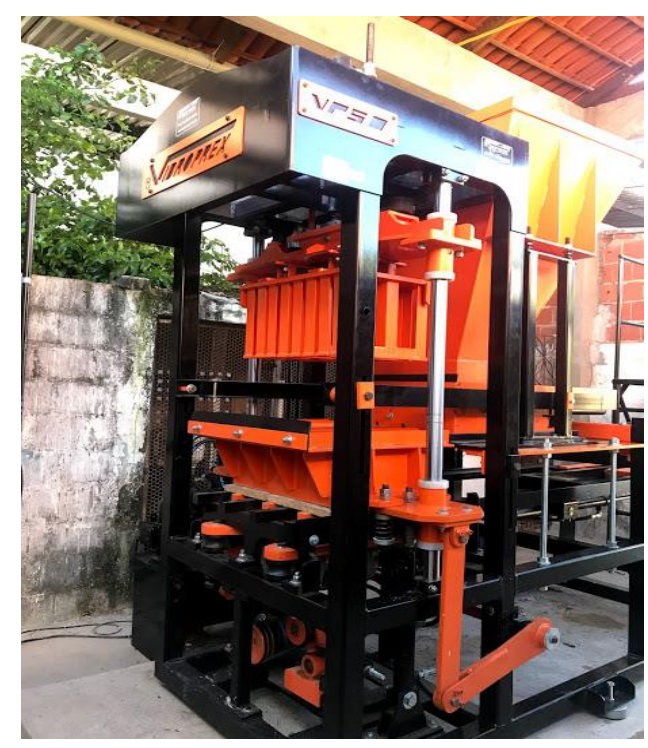

Fonte: Autora (2018). 
É importante lembrar que na fabricação dos traços de substituição foram seguidos todos os procedimentos utilizados na fabricação do traço de referência (TR), ou seja, os seis traços de concreto adotaram rigorosamente o mesmo processo de dosagem, mistura, e transporte, sendo fabricados um por vez. Para confecção dos concretos seguiu-se os seguintes passos: os materiais foram pesados separadamente nos baldes, ilustrado na Figura 23 (a) transportados e lançados separadamente na betoneira em funcionamento, girando em movimento circular, conforme ilustra Figura 23 (b). A Figura 23 (c) ilustra o concreto misturado dentro da betoneira. Importante frisar que todo o processo de pesagem, transporte, operação e manuseio foi inteiramente manual.

Figura 23 - Processo de fabricação dos blocos

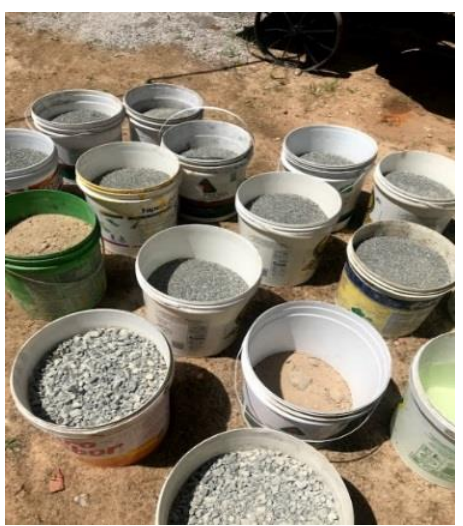

(a) Materiais pesados e separados em baldes de plástico

Fonte: Autora (2018).

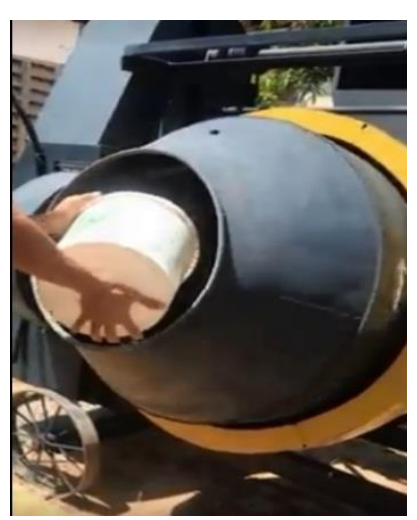

(b) Lançamento dos materiais na betoneira

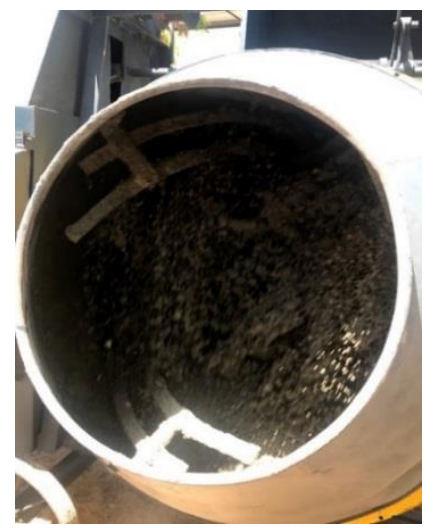

(c) Materiais na betoneira

Na continuidade do processo de fabricação dos blocos, com o concreto preparado, retira-se uma amostra para o ensaio do concreto no estado fresco, o restante mistura foi lançado da betoneira em baldes e transportados até a vibroprensa, onde foram moldados os blocos.

O tipo de concreto utilizado na fabricação de pavers é conhecido como concreto seco ou como concreto sem abatimento. Esse tipo foi assim denominado pela sua característica e tipo de consistência, onde sua mistura é levemente umedecida, fazendo com que sua aparência seja parecida com uma "farofa". Ele tem como uma de suas características a capacidade de manter sua forma depois de adensado e prensado (SILVEIRA, 2015).

O ensaio para concreto seco, descrito na norma DNIT 064/2004 - ME, prescreve o método de determinação da consistência do concreto pelo consistômetro "VeBe", a Figura 24 ilustra o equipamento. 
Figura 24 - Consistômetro "VeBe

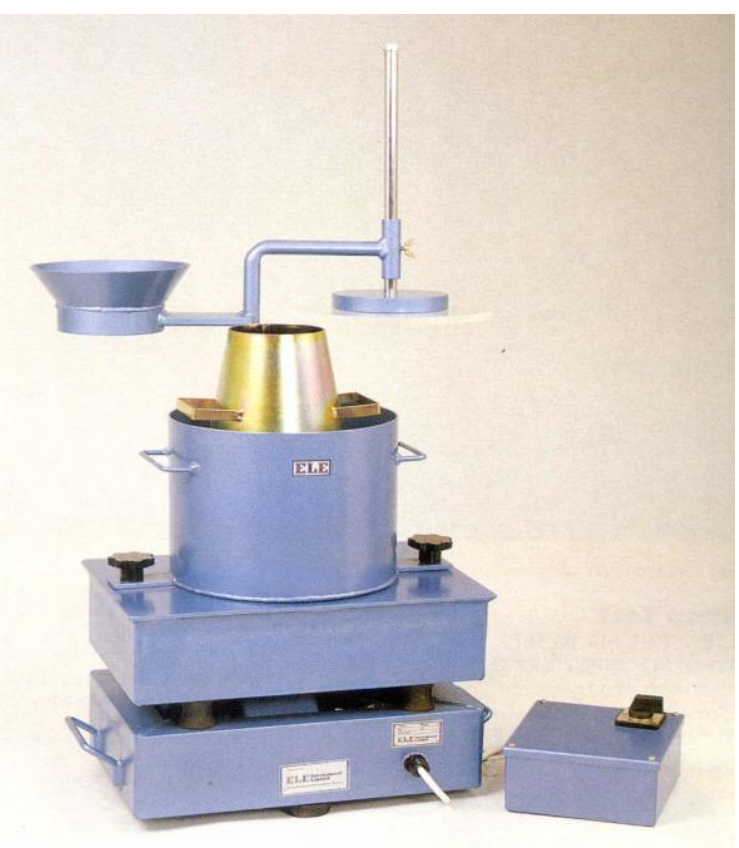

Fonte: Adaptado pela Autora (DNIT 064/2004 - ME).

Nesta pesquisa foi utilizado um "VeBe" modificado, onde usa-se um contrapeso sobre a placa de vidro. Kokubu (1995) explicou diferentes padrões e resultados conforme o tipo de contrapeso utilizado sobre a amostra de concreto no recipiente cilíndrico do aparelho "VeBe". Segundo a ASTM C1170, o contrapeso utilizado é de 22,7 kg e a American Corps of Engineering especifica um contrapeso de $12,5 \mathrm{~kg}$, ao vibrar a mesa em uma intensidade de 60 Hz. O Instituto Americano do Concreto na ACI 211.3 - 75 (Prática Recomendada para a Seleção e Proporções de Concreto No - Slump), divide a consistência em seis tópicos, partindo de consistência fluida até extremamente seco. A Tabela 11 descreve a classificação de consistência segundo a norma ACI 211.3 - 1975.

Tabela 11 - Classificação Consistência

\begin{tabular}{ccc}
\hline Descrição da consistência & Slump Test $(\mathbf{c m})$ & Tempo "VeBe" (s) \\
\hline Extremamente seco & --- & 32 a 18 \\
Muito Seco & --- & 18 a 10 \\
Seca & 0 a 1 & 10 a 5 \\
Seco para plástico & 1 a 3 & 5 a 3 \\
Plástico & 3 a 5 & 3 a 0 \\
Fluido & 5 a 7 & --- \\
\hline
\end{tabular}

Fonte: Adaptado Segundo AIC 211.3 (1975). 
O experimento com o consistômetro "Vebe" indiretamente impacta na produtividade e no rendimento das empresas, pois com seus resultados é possível selecionar a melhor mistura de concreto para a fabricação das peças. Outro fator é em função da trabalhabilidade que está diretamente ligada ao tempo e energia dispendida para a conformação dos blocos. Uma vez adequada a trabalhabilidade do concreto, os gastos em função da necessidade de energia podem ser minimizados e as máquinas vibroprensas elevam sua produção, e consequentemente a sua vida útil (SILVEIRA, 2015).

Foram realizados ainda ensaios nos blocos já endurecidos de acordo com ABNT NBR 9781:2013, os requisitos e métodos de ensaios exigíveis para aceitação ou rejeição das peças de concreto para pavimentação intertravada. As amostragens para os ensaios de aceitação devem considerar o lote de fabricação, onde de cada lote devem ser retiradas, aleatoriamente, peças inteiras que constituam a amostra representativa, conforme especificado na Tabela 12.

Tabela 12 - Amostragem para os ensaios nos blocos

\begin{tabular}{lcc}
\hline Propriedades & Amostra por ensaio & Norma vigente ABNT \\
\hline Inspeção visual & $6^{\mathrm{a}}$ & NBR 9781/2013 \\
Avaliação dimensional & $6^{\mathrm{a}}$ & NBR 9781/2013 \\
Absorção de água & 3 & NBR 9781/2013 \\
Resistência à compressão & 6 & NBR 9781/2013 \\
Resistência à abrasão & $3^{\mathrm{b}}$ & NBR 12042/2013 \\
\hline a As peças amostradas podem ser utilizadas também para os ensaios de resistência à compressão ou \\
abrasão. \\
b Ensaio facultativo
\end{tabular}

Fonte: Adaptado (ABNT NBR 9781:2013).

De acordo com ABNT NBR 9781 (2013), para os ensaios de inspeção visual, avaliação dimensional e resistência à compressão, a amostra deve ter no mínimo seis peças para cada lote de fabricação até $300 \mathrm{~m}^{2}$ e uma peça adicional para cada $50 \mathrm{~m}^{2}$ suplementar, até perfazer a amostra máxima de 32 peças.

Em se tratando do ensaio de resistência à Abrasão empregou-se as recomendações da norma ABNT NBR 12042/2013, utilizando-se o equipamento ilustrado na Figura 25. Nesse ensaio foram utilizadas duas peças de bloco para cada traço fabricado, onde foram cortadas com disco diamantado duas amostras de cada bloco nas seguintes dimensões $(70 \mathrm{~mm} \times 70 \mathrm{~mm} \times 3$ $\mathrm{mm}$ ). Para a execução deste, primeiramente foi feita a leitura inicial dos corpos-de-prova. A seguir, iniciou-se o ensaio com percursos estipulados e feitas medições conforme indicadas na norma. 
Figura 25 - Equipamento utilizado para o ensaio de Abrasão por desgaste

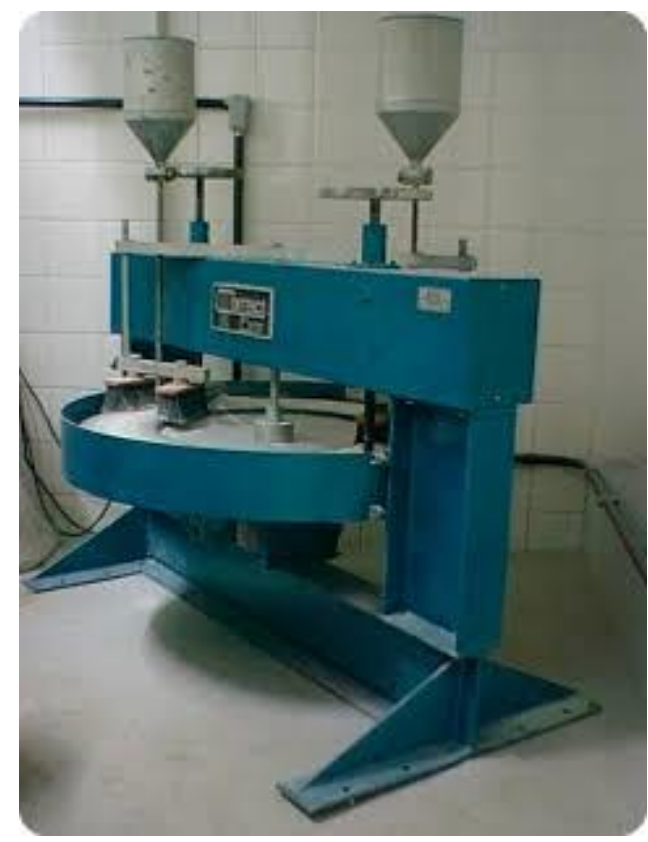

Fonte: NUTEC (2018)

O estudo da Estatística apresenta medidas de dispersão que permitem a análise da dispersão dos dados. Entre elas a variância que é uma medida de dispersão que mostra quão distantes os valores estão da média. Quanto maior for a variância, mais distantes da média estarão os valores, e quanto menor for a variância, mais próximos os valores estarão da média (RIBEIRO, 2018). Para as análises estatísticas dos dados foi utilizado como ferramenta o Excel 2013.

\subsection{Considerações finais}

Neste Capítulo foram expostos os materiais utilizados na pesquisa bem como os métodos de caracterização. Também foram abordados os procedimentos para fabricação dos BCPI e ensaios mecânicos e ambientais. Os ensaios desta foram realizados nos Laboratório de Mecânica Pavimentos, Laboratório de Materiais de Construção Civil, Laboratório de Física, Laboratório de Saneamento Ambiental, todos na UFC.

No Capítulo 4, que se segue, serão apresentados e discutidos os resultados dos ensaios realizados no programa experimental da pesquisa. 


\section{ANÁLISE E DISCUSSÃO DOS RESULTADOS}

Neste capítulo serão apresentados e discutidos os resultados obtidos em cada uma das partes metodológicas que compõem esta pesquisa. Serão apresentados e discutidos os resultados obtidos dos ensaios de caracterização dos materiais e dos ensaios realizados com concreto em seu estado fresco e endurecido, para que se possa analisar a substituição desse resíduo na produção dos BCPI.

\subsection{Resultados dos Ensaios de Caracterização dos Materiais}

Inicialmente, para melhor definição das frações a serem substituídas, realizou-se o ensaio de granulometria por peneiramento mecânico da cinza pesada (in natura) e dos agregados naturais. A Figura 26 mostra uma visão geral de todas as curvas granulométricas em um só gráfico.

Figura 26 - Resultado da distribuição granulométrica de todos os materiais da pesquisa

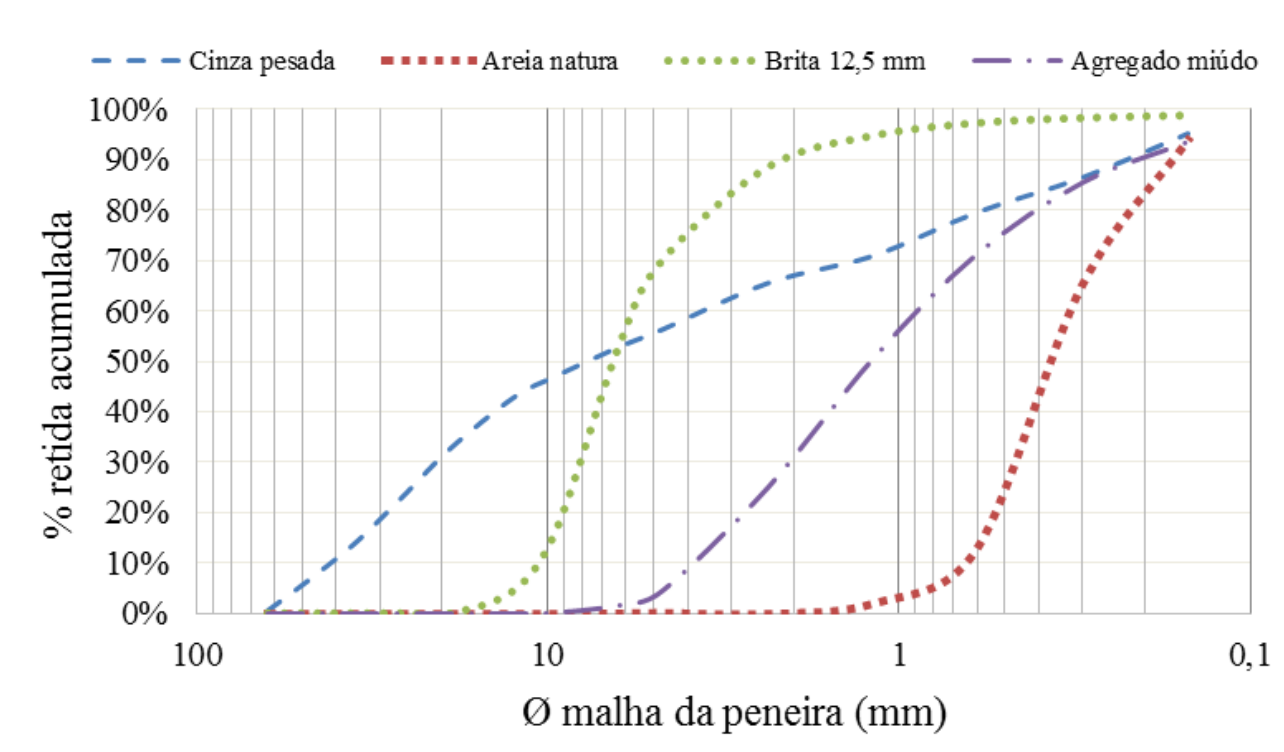

Fonte: Autora (2018).

Comparando-se as curvas granulométricas dos agregados naturais (graúdos e miúdos) com a da cinza pesada em estudo, apresentadas no gráfico da Figura 26, percebe-se que há uma proximidade da porcentagem retida nas frações miúdas, e uma variação maior da cinza na porcentagem graúda. Ressalta-se que os agregados naturais são os sugeridos pela empresa cedente do traço de referência. 
Conforme os resultados apresentados no gráfico da Figura 26 percebe-se que a cinza possui partes graúdas, miúdas e parcela de material fino em sua composição. Para melhor esclarecimento, elaborou-se a Tabela 13.

Tabela 13 - Separação das CPIN, Conforme a Distribuição Granulométrica

\begin{tabular}{ccc}
\hline Agregados & Faixa (mm) & Porcentagem (\%) \\
\hline Agregado Graúdo & Acima de 4,8 & 52,8 \\
Agregado Miúdo & $4,8 \mathrm{~mm}-0,150$ & 42,4 \\
Silte/Argila & $<0,150$ & 4,8 \\
\hline
\end{tabular}

Fonte: Elaborado pela Autora (2018).

Ao analisar os resultados expostos na Tabela 13 e nos Gráficos das Figuras 26, percebe-se um certo equilíbrio na composição granulométrica da cinza (in natura).

De acordo com a ABNT NBR 7211:2009, para utilizar quaisquer materiais na fabricação do concreto, seja, natural, artificial ou resíduo é recomendado que esses estejam dentro dos limites de faixa granulométrica utilizáveis para agregado graúdo e para agregado miúdo. Para isso, foram elaborados gráficos com a distribuição das cinzas divididas em duas frações: graúda (passante na $75 \mathrm{~mm}$ e retida na 4,75 mm) e miúda (passante na 4,75 mm e retida na $150 \mu \mathrm{m})$. Foram elaborados gráficos para ambas as faixas ilustrados nas Figuras 27, 28 e 29.

Figura 27 - Resultado da comparação com os limites para agregados graúdos (natural e CPIN)

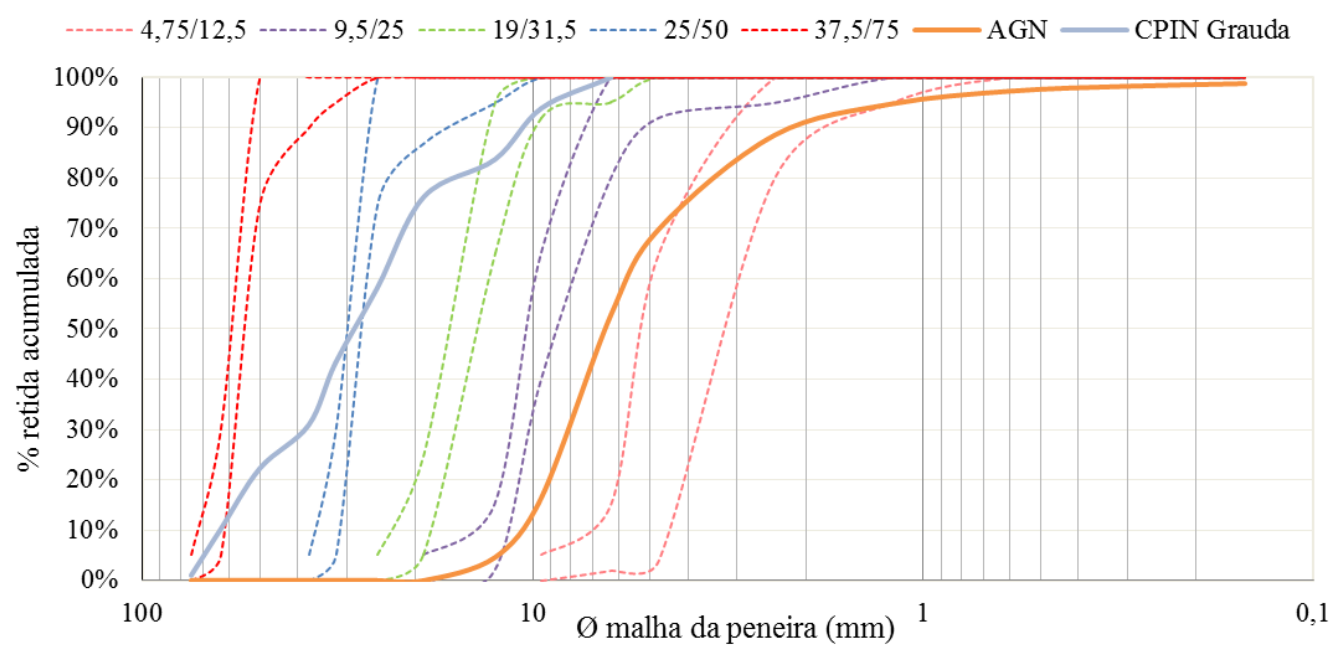

Fonte: Autora (2018). 
Figura 28 - Resultado da comparação com os limites para agregados miúdo (natural e CPIN)

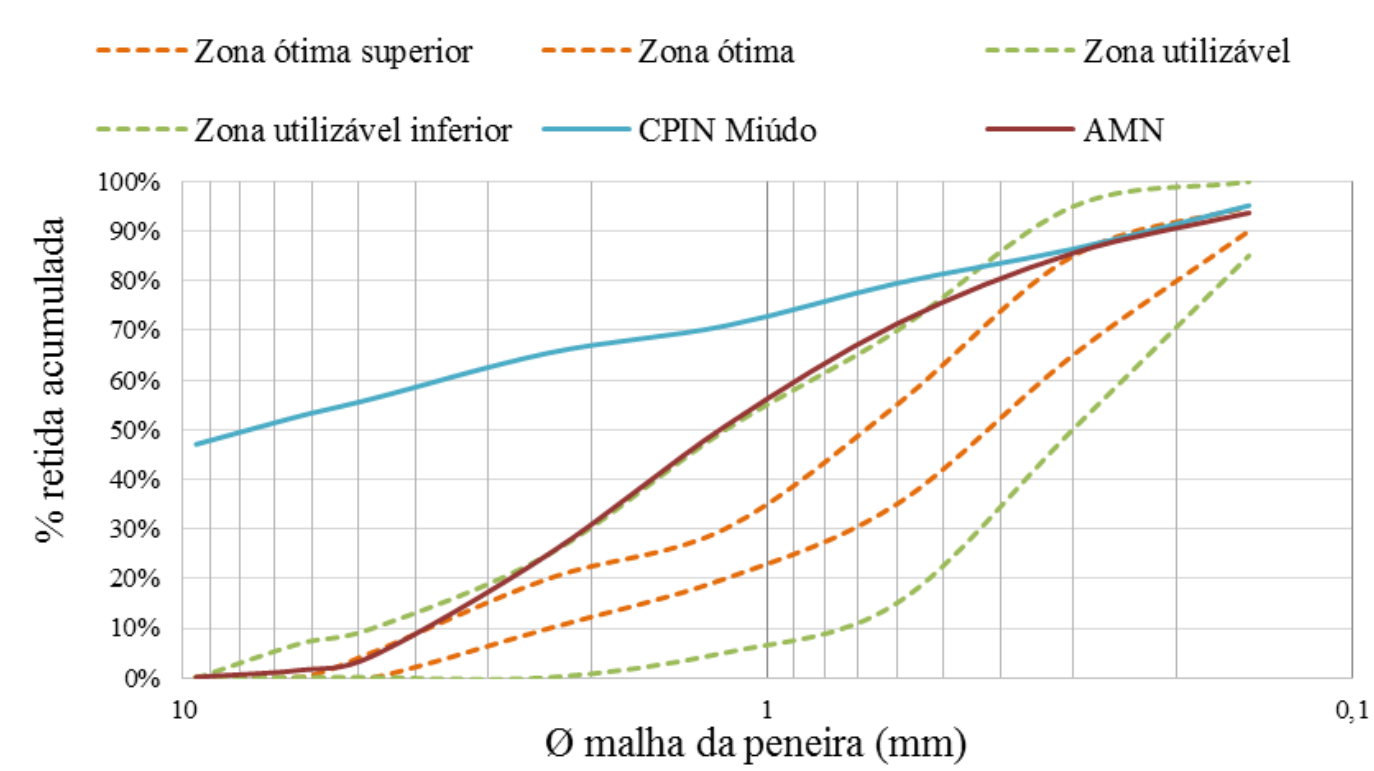

Fonte: Autora (2018).

Figura 29 - Resultada da comparação com os limites areia natural

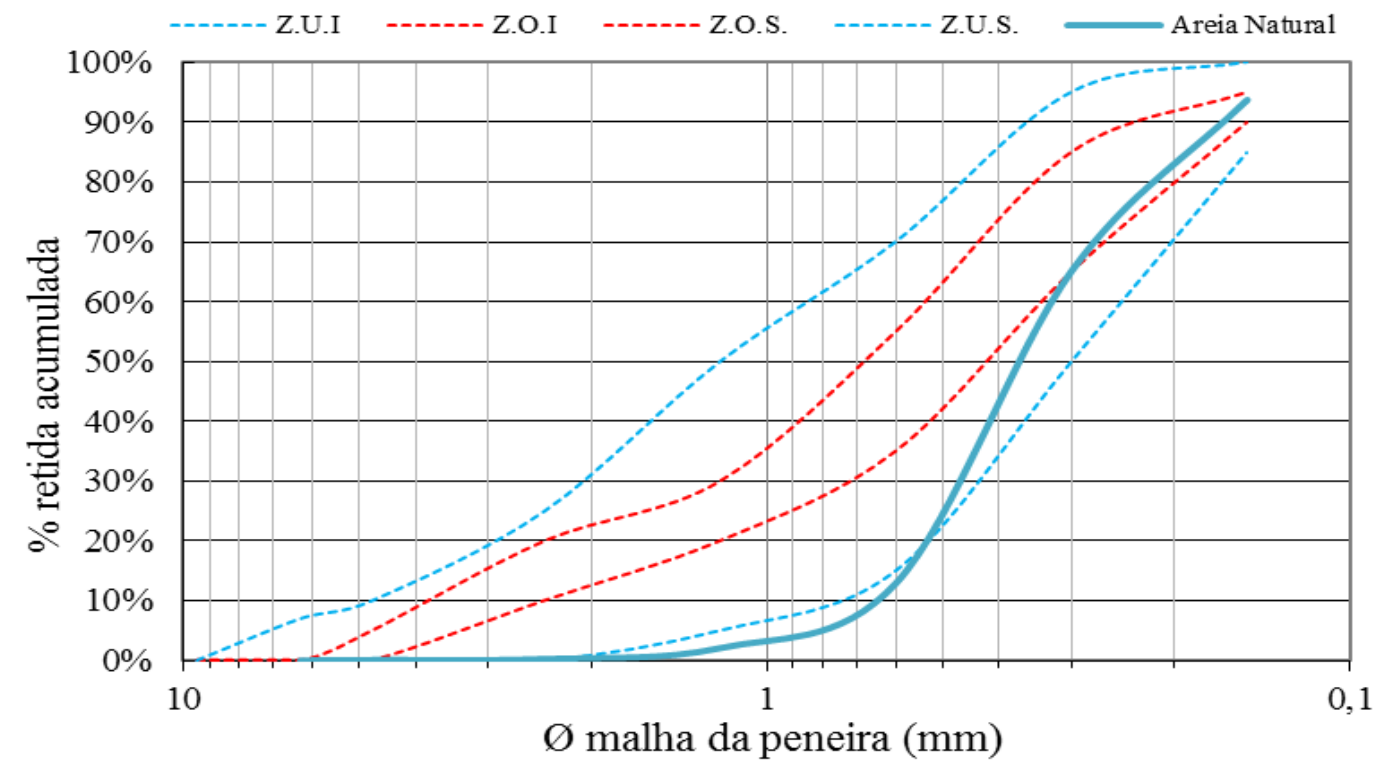

Fonte: Autora (2018).

A partir da análise granulométrica dos gráficos da comparação de limites utilizáveis da ABNT NBR 7211:2009, percebeu-se que a cinza pesada (in natura), no seu estado natural, não se enquadraria em nenhuma faixa utilizável. Assim, segundo a referida norma, não poderia ser reutilizada como agregado graúdo ou miúdo. Com base nestes resultados, optou-se por beneficiar toda a CPIN, fracionando, e posteriormente dosando-a nas mesmas porcentagens 
retidas dos AMN. O gráfico da Figura 30 apresenta o comportamento das curvas dos dois agregados miúdos após o fracionamento.

Figura 30 - Resultado das curvas granulométricas dos AMN e AMCP após o fracionamento

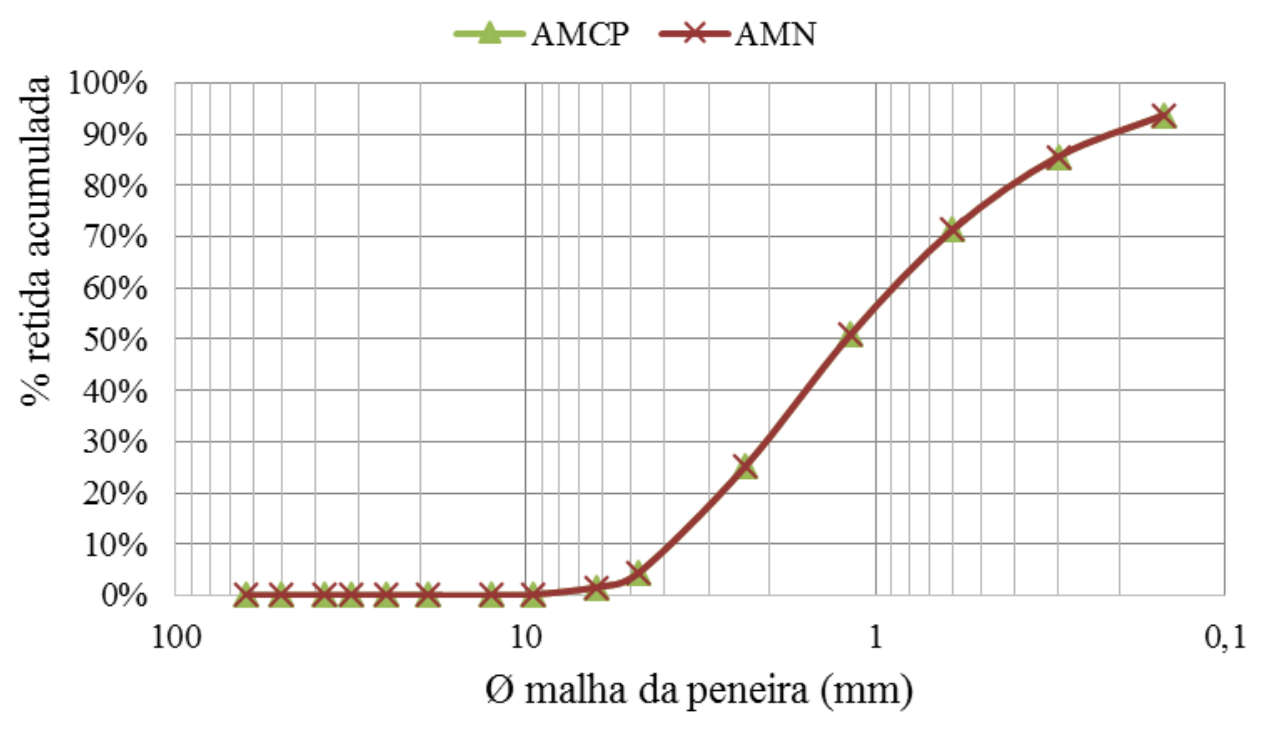

Fonte: Autora (2018).

Através dos resultados da granulometria (ABNT NBR NM 248:2003), obteve-se o diâmetro máximo característico (Dmáx) sendo este considerável tanto para a dosagem do concreto quanto para o seu tipo de aplicação. O módulo de finura (MF) é uma grandeza adimensional que quanto menor for seu valor, sugere que o material é fino, apresentados na Tabela 14.

Tabela 14 - Resultados Dmáx e MF

\begin{tabular}{ccccc}
\hline Índice físico & CPIN & AGN & AMN & ARN \\
\hline $\mathrm{D}_{\text {màx }}$ & $63,0 \mathrm{~mm}$ & $9,5 \mathrm{~mm}$ & $4,75 \mathrm{~mm}$ & $1,18 \mathrm{~mm}$ \\
MF & 5,46 & 5,37 & 3,31 & 1,74 \\
\hline
\end{tabular}

Fonte: Elaborado pela Autora (2018).

A especificação de agregado para concreto de acordo com a ABNT NBR 7211:2009 estabelece que o índice de desgaste por Abrasão "Los Angeles" não deve ser superior a 50\% em massa do material inicial, para o uso de agregado graúdo. Esse ensaio foi realizado nos materiais de pesquisa, obtendo respectivamente os seguintes valores: $\mathrm{CPIN}=79 \%$ onde houve um excedente ao recomendado em norma, e no $\mathrm{AGN}=17 \%$ atendeu ao limite estabelecido dentro 
dos índices recomendado. A partir desses resultados optou-se por não utilizar a fração graúda da cinza.

Os resultados para a determinação da massa específica, absorção de água, material pulverulento, massa unitária, reatividade álcali-agregado, teor de cloretos, sulfatos e sais solúveis, foram realizados para as cinzas pesadas e agregados naturais apresentados na Tabela 15.

Tabela 15 - Resumos dos Ensaios de Caracterização

\begin{tabular}{|c|c|c|c|c|c|c|}
\hline \multirow[t]{2}{*}{ NORMAS VIGENTES } & \multicolumn{3}{|c|}{ Agregados Naturais } & \multirow{2}{*}{$\begin{array}{l}\text { Cinza Pesada } \\
\text { Beneficiada }\end{array}$} & \multicolumn{2}{|c|}{$\begin{array}{c}\text { Referência } \\
\text { normativa (NBR } \\
\text { 7211:2009) }\end{array}$} \\
\hline & Miúdo & Graúdo & $\begin{array}{c}\text { Areia } \\
\text { Natural }\end{array}$ & & Miúdo & Graúdo \\
\hline $\begin{array}{c}\text { Massa específica }-\mathrm{g} / \mathrm{cm}^{3}(\mathrm{NBR} \\
\text { NM 52/53:2009) }\end{array}$ & 2,48 & 2,51 & 2,52 & 1,52 & \multicolumn{2}{|l|}{-} \\
\hline $\begin{array}{c}\text { Absorção de água \% (NBR NM } \\
\text { 30:2001/53:2009) }\end{array}$ & 1,3 & 0,9 & 2,0 & 1,4 & \multicolumn{2}{|l|}{-} \\
\hline $\begin{array}{c}\text { Material pulverulento \% (NBR } \\
\text { NM 46:2003) }\end{array}$ & 3,8 & 1,3 & 10,6 & 1,6 & 3,0 ou 5,0 & 1,0 \\
\hline $\begin{array}{c}\text { Massa unitária solta }-\mathrm{kg} / \mathrm{m}^{3} \\
\text { (NBR NM 45:2006) - aprox de } 10 \\
\mathrm{~m}^{3}\end{array}$ & 1505 & 1329 & 1304 & 680 & \multicolumn{2}{|l|}{-} \\
\hline $\begin{array}{c}\text { Índice de desgaste por abrasão } \\
\text { "Los Angeles" \% (NBR NM } \\
51: 2001 \text { ) }\end{array}$ & - & 17 & - & 79 & \multicolumn{2}{|r|}{$<50$} \\
\hline $\begin{array}{l}\text { Reatividade álcali-agregado } \\
\text { (NBR 15577-4:2009) }\end{array}$ & $\begin{array}{r}\text { Agrega } \\
\qquad(0,0\end{array}$ & $\begin{array}{l}\text { ido poten } \\
\text { inócuo } \\
00 \text { aos } 30\end{array}$ & $\begin{array}{l}\text { ialmente } \\
\text { dias) }\end{array}$ & $\begin{array}{c}\text { Agregado potencialmente } \\
\text { reativo } \\
(0,476 \text { aos } 30 \text { dias })\end{array}$ & \multicolumn{2}{|c|}{0,19} \\
\hline Cloretos \% (NBR 9917:2009) & \multicolumn{3}{|c|}{$<0,01$} & $<0,01$ & \multicolumn{2}{|c|}{$<0,01$ (protendido) } \\
\hline $\begin{array}{c}\text { Sais Solúveis \% (NBR } \\
\text { 9917:2009) }\end{array}$ & \multicolumn{3}{|c|}{0,16} & 0,20 & \multicolumn{2}{|l|}{-} \\
\hline Sulfatos \% (NBR 9917:2009) & \multicolumn{3}{|c|}{$<0,01$} & $<0,01$ & \multicolumn{2}{|c|}{$<0,1$} \\
\hline
\end{tabular}

Fonte: Elaborado pela Autora com dados obtidos pelos laboratórios colaboradores do projeto (2018).

A Tabela 16 apresenta a análise do AIMS para os AGN, AGCP, AMN e AGCP e resume os resultados (médias) obtidos para as propriedades de forma dos materiais nesta pesquisa. 
Tabela 16 - Resumo dos Resultados Obtidos na Análise do AIMS

\begin{tabular}{ccccc}
\hline \multirow{2}{*}{$\begin{array}{c}\text { Materiais } \\
\text { Analisados }\end{array}$} & Forma 2D & Esfericidade & Angularidade & $\begin{array}{c}\text { Textura } \\
\text { Superficial }\end{array}$ \\
\cline { 2 - 5 } & & $\begin{array}{c}\text { Baixa } \\
\text { esfericidade }\end{array}$ & Subarredondado & Baixa rugosidade \\
AGN & Semicircular & Baixa & Subarredondado & - \\
AMN & & Esfericidade & Subangular & Alta rugosidade \\
AGCP & & Subangular & \\
AMCP & Semialongado & & \multicolumn{4}{c}{ Sudes de forma } \\
\hline
\end{tabular}

Fonte: Elaborado pela Autora de acordo como dados obtidos pelo AIMS (2018).

A Figura 31 mostra um exemplo das imagens geradas pelo AIMS por peneira, para análise dos parâmetros de forma 2D e angularidade.

Figura 31 - Imagens de forma geradas pelo AIMS por peneira (cinza pesada)

\begin{tabular}{|l|l|l|l|l|}
\hline & \\
\hline
\end{tabular}

Fonte: Elaborado pela Autora de acordo como dados obtidos pelo AIMS (2018).

A Figura 32 ilustra um exemplo das imagens geradas pelo AIMS para análise dos parâmetros de textura superficial dos agregados naturais e da cinza pesada. Observa-se através das imagens que o agregando natural aparenta uma superfície lisa, no entanto, a cinza pesada apesenta uma superfície porosa. 
Figura 32 - Imagens de superfície geradas pelo AIMS

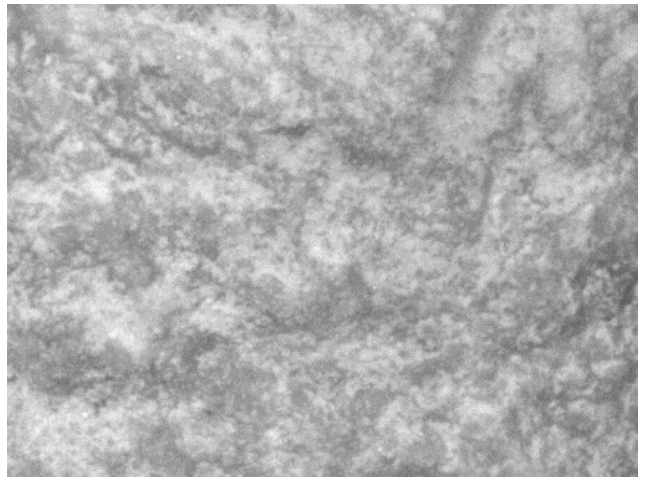

(a) Agregado natural

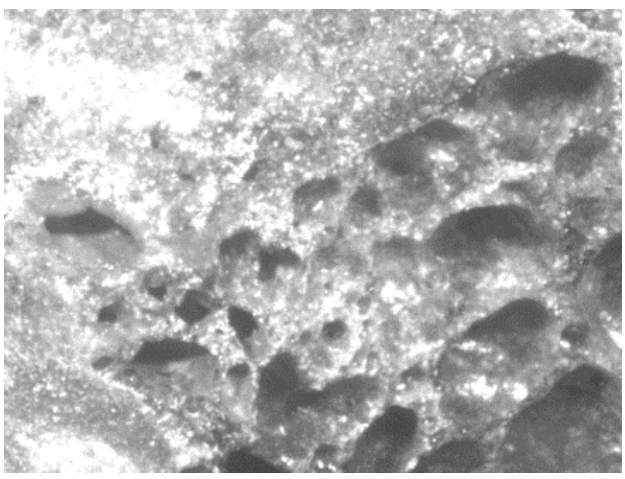

(b) Cinza pesada

Fonte: Elaborado pela Autora de acordo como dados obtidos pelo AIMS (2018).

Lixiviação, conforme a NBR 10005 (ABNT, 2004), é a "capacidade de transferência de substancias orgânicas e inorgânicas presentes nos resíduos sólidos, por meio de dissolução no meio extrator", esta norma supracitada fixa os requisitos exigíveis para a obtenção do extrato lixiviado.

Em se tratando de Solubilização, NBR 10006 (ABNT 2004), é o procedimento em que a substância ou produto pode se dissolver em um líquido; é um mecanismo de dissolução de um determinado material ou produto. Com os resultados desses dois ensaios tem-se a classificação dos resíduos sólidos, de acordo com a NBR 10004 (ABNT, 2004), que no caso deste estudo são referentes as cinzas pesadas provenientes da queima do carvão mineral na Usina Termelétrica do Pecém.

A Tabela 17 apresenta os extratos lixiviados e solubilizado dos compostos iônicos e catiônicos para a cinza pesada e valores máximos permitidos (VMP) de com a NBR 10005 (ABNT, 2004). Onde observa-se, que alguns valores amostrais ultrapassaram os limites prescritos pela norma. 
Tabela 17 - Extrato Lixiviado e Solubilizado da Cinza Pesada

\begin{tabular}{ccccc}
\hline \multirow{2}{*}{$\begin{array}{c}\text { Concentração } \\
(\mathbf{p p m})\end{array}$} & Lixiviado & VMP (lixiviado) & Solubilizado & VMP (solubilizado) \\
\cline { 2 - 5 } Fluoreto & 3,59 & 150,0 & 5,75 & 1,5 \\
Cloreto & 4,33 & - & 19,31 & 250,0 \\
Brometo & 2,32 & - & 1,01 & - \\
Nitrato & 0,87 & - & 0,91 & 10 \\
Fosfato & 0,53 & - & - & - \\
Sulfato & 146,81 & - & 750,99 & 250,0 \\
Cromo & 0,201 & 5 & 0,179 & 0,05 \\
Ferro & 0,009 & - & 0,024 & 0,3 \\
Cobre & 0,024 & - & 0,105 & 2,0 \\
Níquel & 0,067 & - & 0,079 & - \\
Manganês & 0,063 & - & 0,067 & 0,1 \\
\hline
\end{tabular}

Fonte: Elaborado pela Autora (2018)

Assim, a cinza pesada classificou-se como resíduos Classe II A - não perigosos e não inertes, pois os resultados obtidos nestes ensaios são pertinentes, mesmo que os materiais alternativos estudados possam oferecer ao meio ambiente possíveis riscos de contaminação no que se refere à disposição inadequada, podendo contaminar os solos e os lençóis freáticos, como também reservatórios superficiais de água; o seu manuseio por pessoal desprovido de equipamentos de proteção individual ou contato por indivíduos do entorno aos compostos produzidos pela cinza podem acarretar problemas de saúde.

\subsection{Resultados da Escolha dos Traços}

Iniciou-se essa fase com o fracionamento da cinza pesada (in natura) que depois de seca foi peneirada na mesma composição granulométrica dos agregados naturais, conforme expostos nos itens 3.2.2 e 4.1 desta pesquisa.

De acordo com a escolha pela troca da fração miúda na composição do concreto, descritas3.2.2, optou-se pelo cálculo por substituição em massa de agregados, utilizando-se a Equação 1 (item 3.2.2) e calculando-se o peso dos AMCP que foi substituído nos AMN. Então, determinou-se as seguintes porcentagens de substituição: 10\%, 20\%, 30\%, 40\% e 50\% da 
quantidade de AMN por AMCP para fabricação dos blocos. Os resultados dos cálculos de substituição estão detalhados nas Equações de 2 a 6, expostos na Tabela 18.

$$
\begin{array}{lll}
\mathrm{M}_{\mathrm{as}}=\frac{1,52}{2,48} \times 195 \times 10 \% & \rightarrow & \mathrm{M}_{\mathrm{as}}=11,95 \mathrm{~kg} \\
\mathrm{M}_{\mathrm{as}}=\frac{1,52}{2,48} \times 195 \times 20 \% & \rightarrow & \mathrm{M}_{\mathrm{as}}=23,90 \mathrm{~kg} \\
\mathrm{M}_{\mathrm{as}}=\frac{1,52}{2,48} \times 195 \times 30 \% & \rightarrow & \mathrm{M}_{\mathrm{as}}=35,86 \mathrm{~kg} \\
\mathrm{M}_{\mathrm{as}}=\frac{{ }_{1,52}}{2,48} \times 195 \times 40 \% & \rightarrow & \mathrm{M}_{\mathrm{as}}=47,81 \mathrm{~kg} \\
\mathrm{M}_{\mathrm{as}}=\frac{1,52}{2,48} \times 195 \times 50 \% & \rightarrow & \mathrm{M}_{\mathrm{as}}=59,76 \mathrm{~kg}
\end{array}
$$

Tabela 18 - Resultados em Peso da Substituição da AMCP para $1 \mathrm{~m}^{3}$ de Concreto

\begin{tabular}{cccccccc}
\hline \multirow{2}{*}{ Traço \% } & \multicolumn{7}{c}{ Consumo dos Materiais (kg) } \\
\cline { 2 - 8 } & CIMENTO & ARN & AMN & AMCP & AGN & Água & Aditivo \\
\hline TR & 142,86 & 128,57 & 557,14 & - & 171,43 & 60,00 & 0,11 \\
T10 & 142,86 & 128,57 & 501,42 & 34,14 & 171,43 & 60,00 & 0,11 \\
T20 & 142,86 & 128,57 & 445,71 & 68,28 & 171,43 & 60,00 & 0,11 \\
T30 & 142,86 & 128,57 & 389,99 & 102,45 & 171,43 & 60,00 & 0,11 \\
T40 & 142,86 & 128,57 & 334,28 & 136,60 & 171,43 & 60,00 & 0,11 \\
T50 & 142,86 & 128,57 & 278,57 & 170,74 & 171,43 & 60,00 & 0,11 \\
\hline
\end{tabular}

Fonte: Elaborada pela Autora (2018).

\subsection{Resultados da Fabricação dos Blocos e da Realização dos Ensaios Normatizados}

Nessa fase, foi acompanhado todo o processo de fabricação do concreto, moldagem e cura dos blocos. Após o período de cura de 24 horas, coberto por uma lona, empilhou-se todos os blocos em uma calçada. Após a definição de substituição para os traços, descritos no item 3.2.2, o primeiro traço fabricado foi o TR e a sequência de fabricação dos demais foi de ordem crescente de substituição até 50.

O procedimento para determinação da consistência do concreto seco no estado fresco foi realizado nos seis traços produzidos nesta pesquisa, utilizando-se o método de determinação da consistência do concreto pelo consistômetro "VeBe" (modificado), onde baseia-se no desempenho das máquinas de vibroprensas utilizadas para fabricação de blocos de concreto para pavimentos intertravados, que necessitam do uso de concreto de característica extremamente seca. 
Assim, como as vibroprensas trabalham com uma vibração potente e força de compressão sobre o concreto, o ensaio com o consistômetro "VeBe" modificado se enquadra e melhor assemelha a esse processo.

Este ensaio pode ser realizado tanto em laboratório quanto "in situ” sobre mistura de concreto pronta para despejar no local. No que se refere à pesquisa, ele foi realizado "in situ” imediatamente após o concreto ser fabricado, de acordo com os seguintes passos:

- coletou-se uma quantidade em balde (equivalente a 18 litros) em cada um dos traços rodados;

- lançou-se o concreto no cone que depois , após compactar cada camada a 1/3 da altura com 25 golpes da haste metálica de cheio é socado (25 golpes), Figura 33 (a);

- retira-se o cone e afere-se o abatimento, Figura 33 (b);

- liga-se a mesa vibratória ao mesmo tempo em que solta-se o disco transparente com o peso. No tocante, à pesquisa foi utilizado um disco de peso $=7,2 \mathrm{~kg}$, que ficou sobre a placa de vidro durante os ensaios das amostras de concreto, como ilustrado na Figura 33 (c).

Figura 33 - Procedimentos de Ensaio do consistômetro "VeBe" modificado

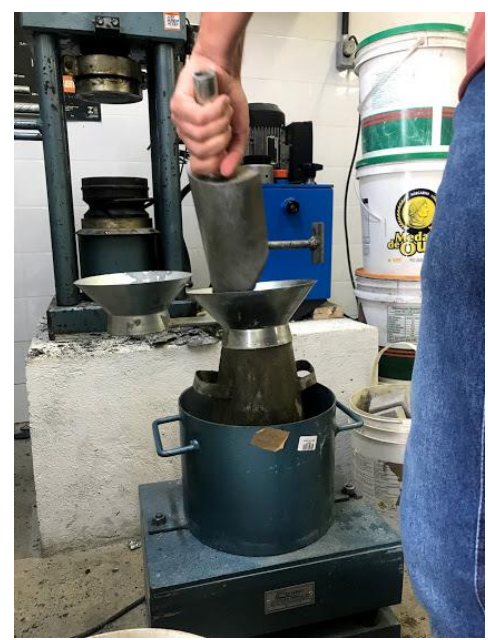

(a) Lançamento do concreto no cone do "VeBe" Fonte: Autora (2018).

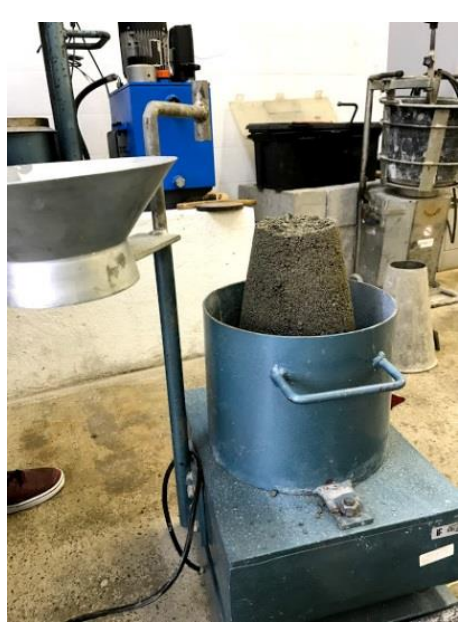

(b) Abatimento do cone no ensaio do "VeBe"

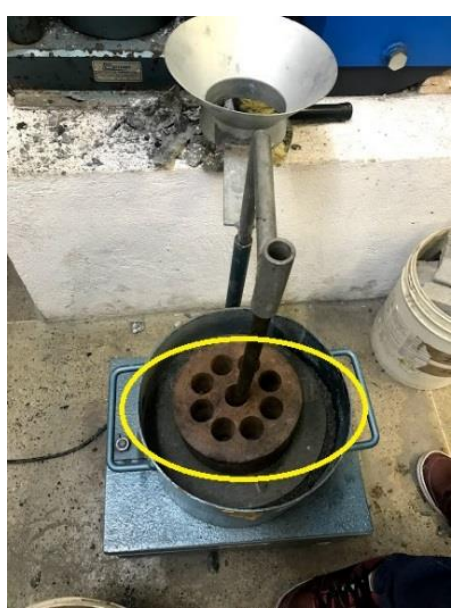

(c) Consistômetro "VeBe" modificado

O experimento com o consistômetro "Vebe" indiretamente impacta na produtividade e no rendimento das empresas, pois com seus resultados é possível selecionar a melhor mistura de concreto para a fabricação das peças. Outro fator é em função da trabalhabilidade que está diretamente ligada ao tempo e energia dispendida para a conformação 
dos blocos. Uma vez adequada a trabalhabilidade do concreto, os gastos em função da necessidade de energia podem ser minimizados e as máquinas vibroprensas elevam sua produção, e consequentemente a sua vida útil (SILVEIRA, 2015).

A consistência é fornecida conforme a duração de tempo de vibração necessário para o adensamento e a compactação da amostra utilizada. A Tabela 19 apresenta os resultados desta pesquisa, de acordo com a classificação da norma ACI 211.3 - 75.

Tabela 19 - Resultados do Consistômetro "VeBe" Modificado para os Seis Traços Investigados

\begin{tabular}{|c|c|c|c|}
\hline \multirow{2}{*}{ Traços } & \multicolumn{2}{|c|}{ Resultados das Amostras Ensaiadas } & \multirow{2}{*}{$\begin{array}{l}\text { Descrição da Consistência } \\
\text { AIC } 211.3 \text { (1975) }\end{array}$} \\
\hline & Abatimento (mm) & Tempo "VeBe" (s) & \\
\hline TR & 0 & 30,2 & Extremamente seco \\
\hline $\mathrm{T} 10$ & 0 & 22,3 & Extremamente seco \\
\hline $\mathrm{T} 20$ & 0 & 21,5 & Extremamente seco \\
\hline $\mathrm{T} 30$ & 0 & 21,9 & Extremamente seco \\
\hline $\mathrm{T} 40$ & 0 & 22,1 & Extremamente seco \\
\hline $\mathrm{T} 50$ & 0 & 23,1 & Extremamente seco \\
\hline
\end{tabular}

Fonte: Elaborado pela Autora (2018).

Neste ensaio os tempos "VeBe" entre 18 a 32 segundos é classificado como extremamente seco, para esta classificação recomenda-se métodos de compactação por vibração forte e compressão para concretos com essa característica, como foi o caso dos concretos fabricados nesta pesquisa.

Os blocos foram confeccionados de acordo com o Formato Tipo 1, "tijolinho" ou “paralelepípedo", definidos no Anexo D (ABNT NBR 9781:2013). Foram fabricados cerca de 80 pavers de $10 \mathrm{~cm} \times 20 \mathrm{~cm} \times 10 \mathrm{~cm}$ (largura, comprimento e altura), por traço, desconsiderando os desperdícios no processo.

Os ensaios realizados nos blocos já endurecidos são importantes para a aceitação ou rejeição dos blocos de concreto para pavimentos intertravados. Eles foram executados conforme as exigências da ABNT NBR 978 (2013). O primeiro ensaio realizado foi o de análise visual, onde foram avaliadas seis peças de cada traço fabricado, totalizando 36 peças avaliadas. Visualmente, não apresentaram modificações na sua aparência para nenhum dos traços de estudo. Isso está registrado nas Figuras 34 (a) a 34 (f). 
Figura 34 - Resultados do ensaio de inspeção visual

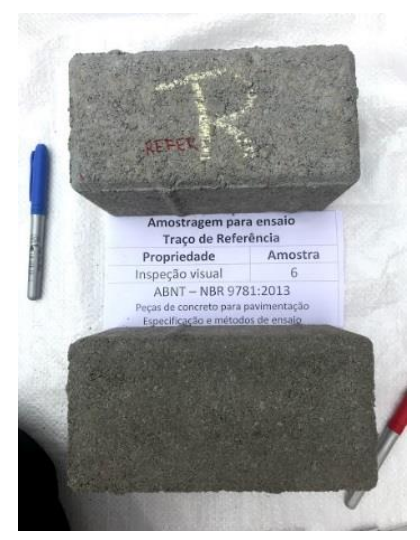

(a) Traço de Referência

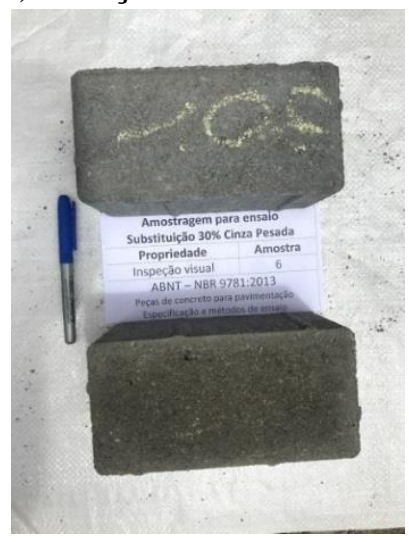

(d) $30 \%$ de substituição Fonte: Autora (2018).

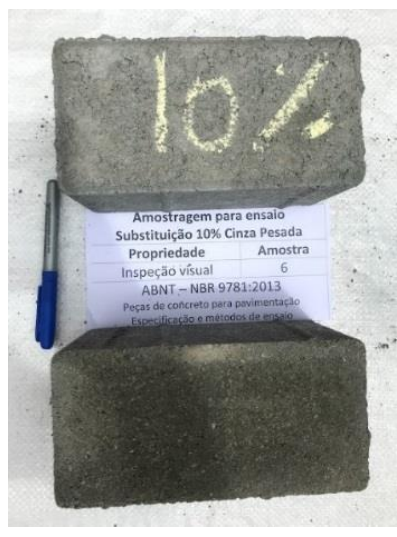

(b) $10 \%$ de substituição

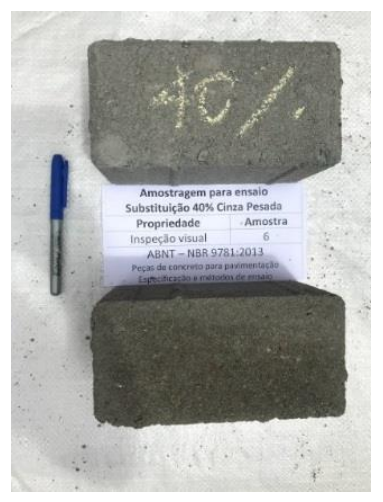

(e) $40 \%$ de substituição

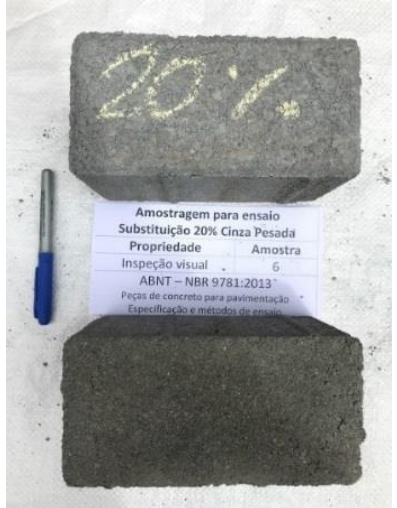

(c) $20 \%$ de substituição

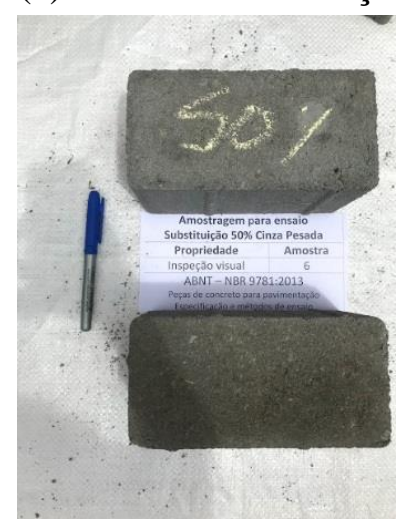

(f) $50 \%$ de substituição

No quesito avaliação dimensional das peças de concreto para pavimento intertravado, cumpriram-se os requisitos em todas as 36 amostras submetidas à inspeção. Essa avaliação está registrada como exemplo na Figura 35. Nessa avaliação também foi visto o índice de forma (IF), que é a relação entre o comprimento e a espessura da peça de concreto. As peças fabricadas nesta pesquisa apresentaram IF igual a 2, atendendo à ABNT NBR 9781:2013 que recomenda, para peças de concreto utilizadas em vias com tráfego de veículos (leves ou pesados) ou áreas de armazenamento, valor de IF menor ou igual a 4.

Figura 35 - Resultado ensaio de avaliação dimensional

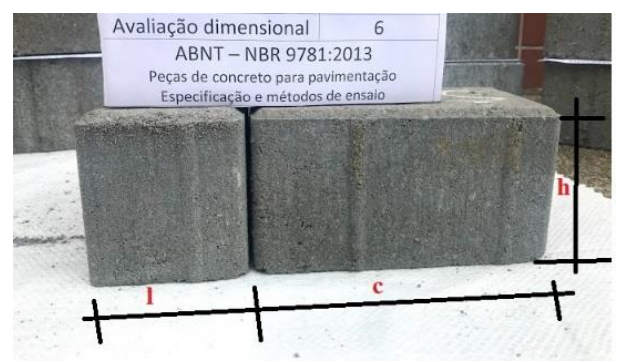

Fonte: Autora (2018). 
Para a avaliação da absorção de água das peças de concreto foram utilizadas três amostras para cada traço fabricado, totalizando dezoito amostras. A Tabela 20 apresenta os valores da massa seca $\left(\mathrm{m}_{1}\right)$, massa saturada $\left(\mathrm{m}_{2}\right)$ e absorção de água de cada amostra e também apresenta a absorção de água média das amostras. Os valores que destacados são os que não atenderam à norma ABNT NBR 9781(2013).

Tabela 20 - Resultados dos Ensaios de Absorção de Água

\begin{tabular}{|c|c|c|c|c|c|}
\hline Traços & Itens avaliados & \multicolumn{3}{|c|}{ Amostras } & $\begin{array}{c}\text { Média da absorção } \\
\text { de água }(\%)\end{array}$ \\
\hline & & TR1 & TR2 & TR3 & \\
\hline \multirow{3}{*}{$\mathrm{TR}$} & Massa seca $\left(\mathrm{m}_{1}\right) \mathrm{em} \mathrm{kg}$ & 4,19 & 4,22 & 4,15 & \multirow{3}{*}{1,89} \\
\hline & Massa saturada $\left(\mathrm{m}_{2}\right) \mathrm{em} \mathrm{kg}$ & 4,26 & 4,30 & 4,24 & \\
\hline & Absorção (A) \% & 1,49 & 1,98 & 2,20 & \\
\hline & & $\mathrm{T} 101$ & $\mathrm{~T} 102$ & $\mathrm{~T} 103$ & \\
\hline \multirow{3}{*}{$\mathrm{T} 10$} & Massa seca $\left(\mathrm{m}_{1}\right) \mathrm{em} \mathrm{kg}$ & 4,02 & 4,22 & 4,02 & \multirow{3}{*}{3,46} \\
\hline & Massa saturada $\left(\mathrm{m}_{2}\right) \mathrm{em} \mathrm{kg}$ & 4,22 & 4,31 & 4,15 & \\
\hline & Absorção (A) \% & 5,06 & 2,10 & 3,23 & \\
\hline & & $\mathrm{T} 201$ & $\mathrm{~T} 202$ & $\mathrm{~T} 203$ & \\
\hline \multirow{3}{*}{$\mathrm{T} 20$} & Massa seca $\left(\mathrm{m}_{1}\right) \mathrm{em} \mathrm{kg}$ & 4,13 & 4,05 & 4,07 & \multirow{3}{*}{7,05} \\
\hline & Massa saturada $\left(\mathrm{m}_{2}\right) \mathrm{em} \mathrm{kg}$ & 4,43 & 4,36 & 4,34 & \\
\hline & Absorção (A) \% & 7,08 & 7,47 & 6,59 & \\
\hline & & $\mathrm{T} 301$ & $\mathrm{~T} 302$ & $\mathrm{~T} 303$ & \\
\hline \multirow{3}{*}{$\mathrm{T} 30$} & Massa seca $\left(\mathrm{m}_{1}\right)$ em kg & 3,68 & 3,85 & 3,89 & \multirow{3}{*}{6,86} \\
\hline & Massa saturada $\left(\mathrm{m}_{2}\right) \mathrm{em} \mathrm{kg}$ & 4,01 & 4,11 & 4,08 & \\
\hline & Absorção (A) \% & 8,89 & 6,76 & 4,92 & \\
\hline & & $\mathrm{T} 401$ & $\mathrm{~T} 402$ & $\mathrm{~T} 403$ & \\
\hline \multirow{3}{*}{$\mathrm{T} 40$} & Massa seca $\left(m_{1}\right)$ em kg & 3,70 & 3,62 & 3,68 & \multirow{3}{*}{8,80} \\
\hline & Massa saturada $\left(\mathrm{m}_{2}\right) \mathrm{em} \mathrm{kg}$ & 3,97 & 3,97 & 4,02 & \\
\hline & Absorção (A) \% & 7,37 & 9,64 & 9,39 & \\
\hline & & T501 & T502 & T503 & \\
\hline \multirow{3}{*}{$\mathrm{T} 50$} & Massa seca $\left(\mathrm{m}_{1}\right) \mathrm{em} \mathrm{kg}$ & 3,70 & 3,56 & 3,67 & \multirow{3}{*}{7,98} \\
\hline & Massa saturada $\left(\mathrm{m}_{2}\right) \mathrm{em} \mathrm{kg}$ & 3,99 & 3,89 & 3,90 & \\
\hline & Absorção (A) \% & 7,86 & 9,35 & 6,75 & \\
\hline
\end{tabular}

Fonte: Elaborado pela Autora (2018).

Os valores individuais da absorção de água das peças de concreto dos seis traços fabricados e o valor limite de absorção de água estabelecido na ABNT NBR 9781 (2013) que é de $7 \%$ para as amostras individuais. A maior absorção de água individual, desconsiderando da análise o traço de referência, foi obtida na peça do T40 que resultou em 9,64\%, e a menor 
ocorreu na peça do T10 que resultou no valor de 2,10\%. Essa avaliação foi feita apenas para as peças com substituição de cinzas. Os resultados mostraram que algumas amostras não apresentaram absorção de água (individual) de acordo com o exigido nas normas técnicas.

O valor limite de absorção de água média que é estabelecido na ABNT NBR 9781 (2013) é de 6\%. No entanto, as peças de concreto que apresentaram maior absorção de água média foi T40 $(8,80 \%)$ e a de menor absorção foi T10 de 3,46\%.

Os resultados mostraram que de todas as amostras, apenas a amostra de T10 apresentou absorção de água média de acordo com o exigido nas normas técnicas. Segundo Cruz (2003), a absorção de água pode mensurar a durabilidade dos blocos, pois aponta o volume de vazios existentes e com isso sua permeabilidade, sendo assim, quanto maior a permeabilidade, menor a resistência ao processo de eflorescência. Por essa razão, é possível afirmar que é imprescindível o controle de absorção de água dos blocos intertravados de concreto quando sua aplicação ocorrer em áreas expostas a umidade.

Com relação a resistência à compressão que é uma propriedade importante do concreto, visto que as normas nacionais e internacionais a adotam como referência para estimar as demais resistências. As peças de pisos intertravados utilizadas para o ensaio de resistência à compressão simples tiveram as superfícies de carregamento retificadas por uma serra, e mantidas submersas em água por 24 horas antes do rompimento que ocorreu em idades de 7 e 28 dias, resultando em um total de 72 blocos rompidos, sendo seis blocos para cada traço e para cada idade. Após a cura, os blocos foram rompidos por uma prensa universal de ensaios de capacidade de $300 \mathrm{kN}$.

As Figuras 36 (a) e (b) ilustram um dos blocos intertravados sendo colocados na prensa para o ensaio de resistência à compressão e ilustram o rompimento da peça. Esse processo foi baseado no método descrito na ABNT NBR 9781 (2013). 
Figura 36 - Exemplo do ensaio de resistência a compressão

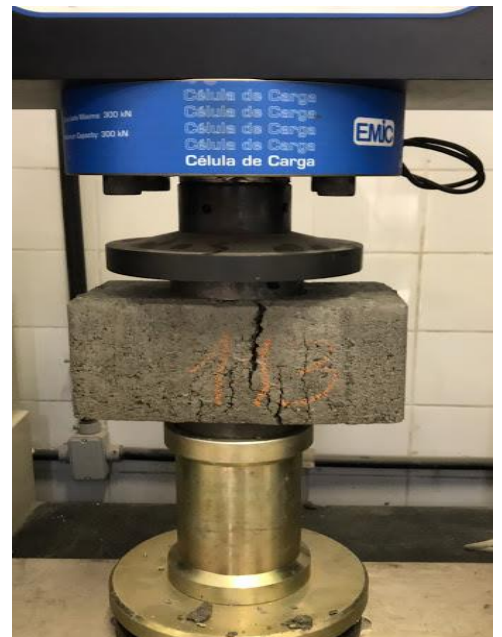

(a) Bloco no momento do rompimento

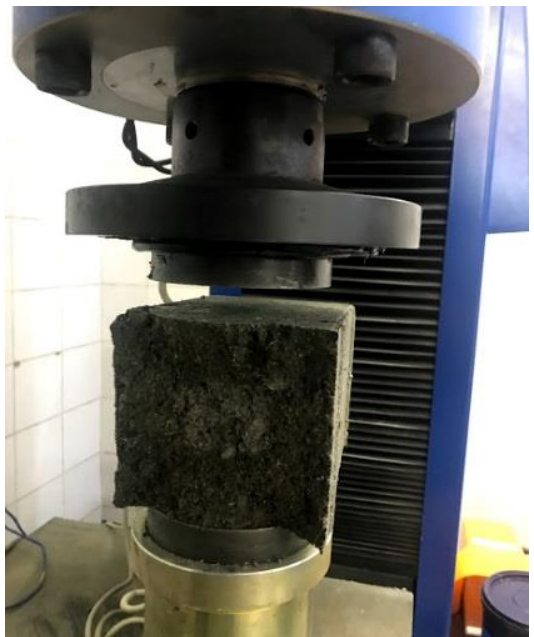

(b) Bloco após rompimento

Fonte: Autora - LMCC UFC (2018).

O principal objetivo do controle da resistência à compressão dos blocos é a obtenção de um valor potencial, único e característico da resistência à compressão de um determinado lote de fabricação de blocos, com o objetivo de comparar esse valor com o exigido na ABNT NBR 9781 (2013). As análises dos resultados da resistência característica estimada à compressão para os blocos intertravados dos traços TR, T10, T20, T30, T40 e T50 estão apresentadas, respectivamente, nas Tabelas de 21 a 22. Para isso, foram aplicadas as equações presentes no Anexo A da ABNT NBR 9781 (2013), onde determinaram-se as resistências individuais e a média, como também a área de carregamento, a força aplicada, fator $p$, o coeficiente de Student, etc., todos expostos de acordo com relatório exigido no referido Anexo.

Para avaliar os resultados obtidos nesse ensaio foi realizada uma análise estatística dos resultados individuais de resistência à compressão dos blocos intertravados. Para tanto, utilizou-se a Estatística Descritiva para a análise dos resultados de cada traço conforme apresentado nas Tabelas de 21 a 22, onde estão apresentados os valores das médias, desvio padrão, variância, coeficiente de variação e amplitude para cada traço aos 7 e 28 dias de idade. 
Tabela 21 - Dados Estatísticos da Resistência à Compressão dos BCPI aos 7 dias

\begin{tabular}{|c|c|c|c|c|c|c|}
\hline & TR & T10 & T20 & T30 & T40 & T50 \\
\hline fp - resistência média (MPa) & 28,19 & 19,09 & 12,25 & 14,11 & 8,28 & 10,24 \\
\hline Desvio Padrão (MPa) & 5,37 & 2,25 & 2,52 & 4,50 & 1,28 & 2,09 \\
\hline Variância & 28,84 & 5,08 & 6,34 & 20,23 & 1,64 & 4,38 \\
\hline Coeficiente de Variação (\%) & 19,05 & 11,81 & 20,55 & 31,89 & 15,46 & 20,45 \\
\hline Amplitude (MPa) & 14,28 & 5,88 & 7,14 & 13,34 & 3,47 & 5,04 \\
\hline
\end{tabular}

Fonte: Elaborado pela Autora (2018).

Tabela 22 - Dados Estatísticos da Resistência à Compressão dos BCPI aos 28 dias

\begin{tabular}{|c|c|c|c|c|c|c|}
\hline & TR & T10 & T20 & T30 & T40 & T50 \\
\hline fp - resistência média (MPa) & 30,03 & 21,65 & 14,53 & 17,13 & 9,26 & 9,35 \\
\hline Desvio Padrão (MPa) & 6,68 & 2,11 & 4,46 & 3,15 & 1,72 & 1,59 \\
\hline Variância & 44,59 & 4,47 & 19,94 & 9,94 & 2,96 & 2,54 \\
\hline Coeficiente de Variação (\%) & 22,24 & 9,77 & 30,74 & 18,40 & 18,59 & 17,05 \\
\hline Amplitude (MPa) & 16,49 & 5,99 & 11,45 & 8,09 & 4,62 & 3,15 \\
\hline
\end{tabular}

Fonte: Elaborado pela Autora (2018).

Analisando os resultados das Tabelas supracitadas, observou-se que aos 7 dias de cura os traços TR e T30 apresentaram desvio padrão mais elevado e obtiveram as duas maiores variâncias se comparado ao demais traços. No entanto, o T10 apresentou baixa dispersão, se comparado aos traços TR, T20 T40 e T50 que apresentaram média dispersão e o T30 apresentou uma alta dispersão.

No entanto, aos 28 dias o traço TR permaneceu com elevado valor de desvio padrão e T20 também apresentou essa característica. Porém, o T10 apresentou baixa dispersão. Mas, os traços TR, T30, T40 e T50 apresentaram média dispersão e o T20 apresentou alta dispersão.

Diversos são os fatores que podem ter causado essas discrepâncias nos dados estatísticos desse ensaio. Porém, nesse estudo não houve tempo para uma análise mais profunda que comprovasse efetivamente qual ou quais as causas reais que resultou esses valores nos resultados apresentados.

Os valores de resistência média e resistência estimada aos 7 e 28 dias dos blocos fabricados nesta pesquisa foram encontrados por meios de relatórios de ensaio exigido no Anexo A da ABNT NBR 9781:2013 e descritos na Tabela 23. 
Tabela 23 - Resistencia Média e Resistência Característica

\begin{tabular}{cc|c|c}
\hline Traço & Idade & $\begin{array}{c}\text { Resistência Média a } \\
\text { Compressão das peças (fp) } \\
(\mathbf{M P a})\end{array}$ & $\begin{array}{c}\text { Resistência Característica a } \\
\text { Compressão Estimada (fpk) } \\
\text { (MPa) }\end{array}$ \\
\hline \multirow{2}{*}{ TR } & 7 & 28,19 & 23,25 \\
& 28 & 30,03 & 23,89 \\
T10 & 7 & 19,09 & 17,02 \\
& 28 & 21,65 & 19,7 \\
T20 & 7 & 12,25 & 9,93 \\
& 28 & 14,53 & 10,42 \\
T30 & 7 & 14,11 & 9,97 \\
& 28 & 17,13 & 14,23 \\
T40 & 7 & 8,28 & 7,10 \\
& 28 & 9,26 & 7,67 \\
T50 & 7 & 10,24 & 8,31 \\
& 28 & 9,35 & 7,88 \\
\hline
\end{tabular}

Fonte: Elaborado pela Autora (2018).

De acordo com a Tabela 23 foi elaborado um gráfico ilustrado na Figura 37, onde pode-se perceber que houve uma diminuição das resistências a compressão (estimada e média) que pode ter ocorrido pelas características de que as cinzas tendem a absorver grande quantidade de água; isto pôde ser observado nos blocos com maior teor de substituição de cinza.

Figura 37 - Resultado do ensaio de resistência à compressão dos BCPI

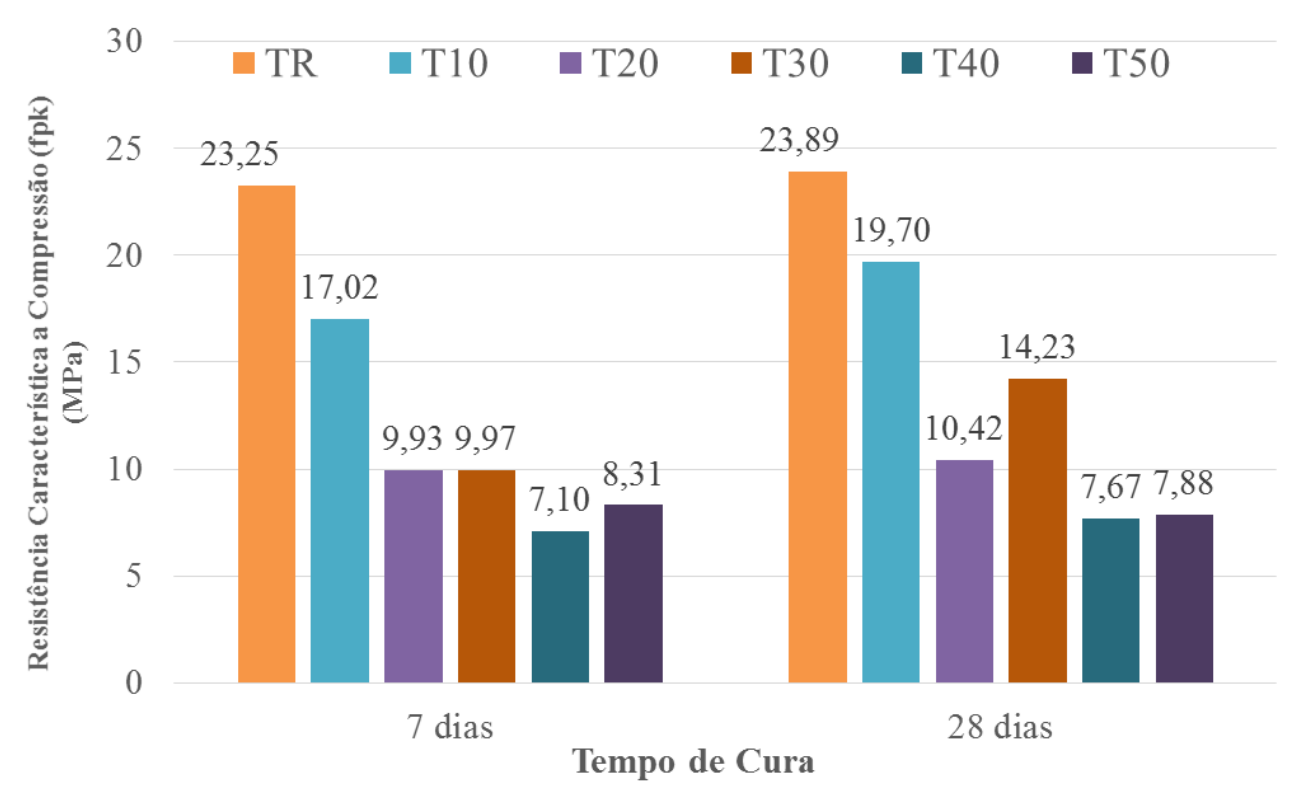

Fonte: Autora (2018). 
Ainda, pode ser observado na Figura 36 uma redução na resistência à compressão com adição de cinza em todos os teores de substituição, em relação ao traço de referência e em todas as idades.

No entanto, aos 28 dias observa-se um maior incremento na resistência para os T10, T20, T30 e T40 e uma redução de T50 em comparação ao tempo de cura de 7 dias, esse fato pode ser atribuído ao indicativo potencial de pozolanicidade das cinzas pesadas, isto pode levar ao um ganho maior de resistência a idades superiores a 28 dias. Ainda que os resultados obtidos não atendem ao preconizado na norma que exige valores de resistência a compressão simples superiores a $35 \mathrm{MPa}$ para tráfego de veículos. Entretanto, o uso dos blocos fabricados com cinza pesada pode ser recomendado para uso em calçadas, passeios, públicos, praças, e urbanização em geral.

O resultado do ensaio de resistência à Abrasão é dado pela diferença entre as médias das leituras efetuadas em quatro pontos, antes e após o ensaio, quando percorridos $500 \mathrm{~m} \mathrm{e}$ $1000 \mathrm{~m}$.

Os procedimentos de avaliação para os resultados do ensaio de resistência a Abrasão alcançados na pesquisa foram analisados de acordo com recomendações da ABNT NBR 9781:2013. Os desgastes á abrasão aos 28 dias de idade dos traços produzidos (referência e com \% de substituição de cinza), atenderam aos critérios para resistência à abrasão exigidos pela referida norma, tanto para o critério de solicitação de tráfego de pedestres, veículos leves e veículos comerciais de linha, quanto para o tráfego de veículos especiais e solicitações capazes de produzir efeitos de abrasão acentuados.

Dos traços de substituição, o T50\% foi o traço que obteve maior desgaste. O gráfico da Figura 38 ilustra o desgaste nos corpos de-provas com 250 voltas e 500 voltas para o corpo de prova $1(\mathrm{CP} 1)$ e corpo de prova $2(\mathrm{CP} 2)$ de todas as amostras dos traços fabricados. 
Figura 38 - Resultado do ensaio de desgaste à abrasão para CP1 e CP2 de cada traço

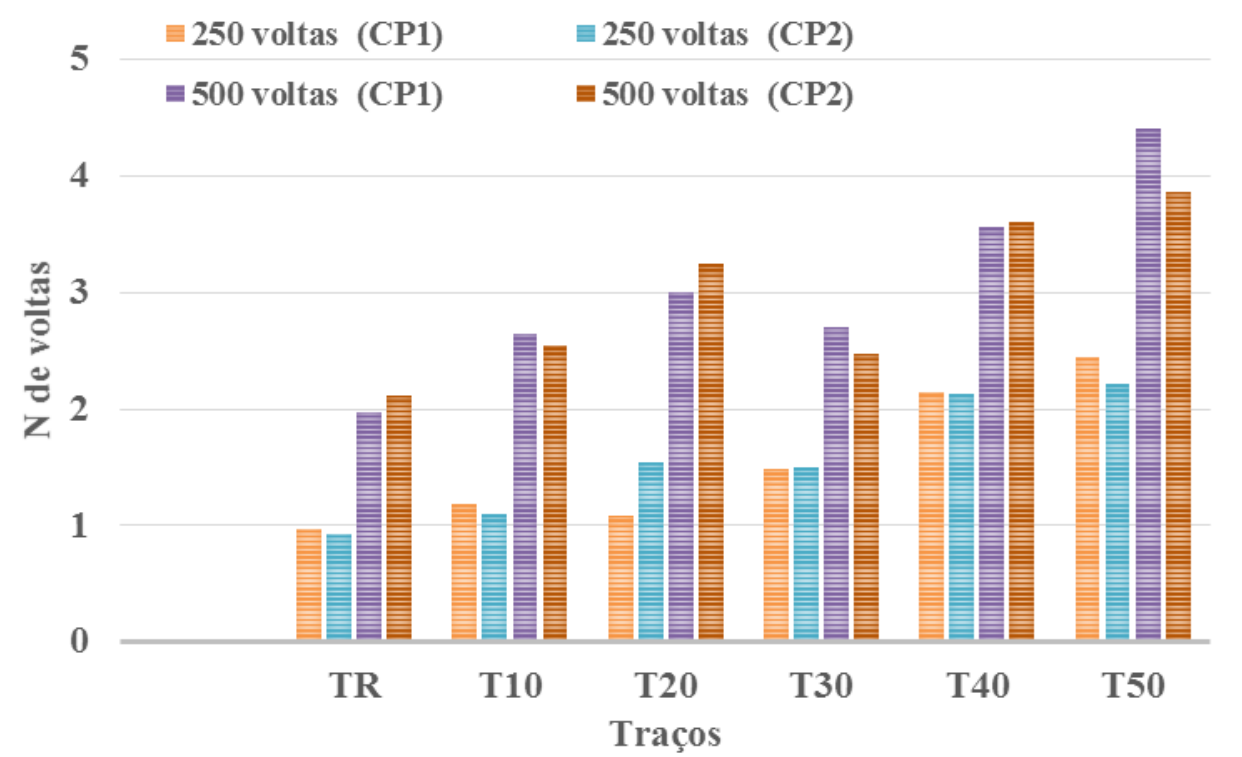

Fonte: Autora (2018).

\subsection{Considerações finais}

Neste Capítulo foram apresentados os resultados da seleção e caracterização dos mateias utilizados na pesquisa, bem como os resultados da fabricação dos BCPI e dos ensaios mecânicos dos blocos.

No Capítulo 5, que se segue, serão apresentadas as principais conclusões com base nos resultados adquiridos no programa experimental desta pesquisa. 


\section{CONCLUSÕES E RECOMENDAÇÕES}

\subsection{Considerações}

As conclusões apresentadas neste capítulo baseiam-se nos resultados do programa experimental executado, abordando as principais constatações e as sugestões para trabalhos futuros.

Considerando que há a necessidade de desenvolvimento de mais estudos que substituam o agregado natural por resíduos, em serviços de pavimentação, buscou-se utilizar cinza pesada de termoelétrica para a fabricação dos BCPI. Para tanto, foram testados diferentes percentuais de substituições dos agregados miúdos por cinza pesada na composição do concreto produzido para confecção dos blocos desse estudo.

$\mathrm{Na}$ avaliação dos destes, de acordo com as recomendações da ABNT NBR 9781:2013, verificou-se que o traço de referência utilizado na pesquisa não atingiu a resistência mínima exigida. Isso, também foi verificado nos blocos fabricados com as substituições das cinzas pesadas. Esses resultados levam a um questionamento do que está preconizado em norma, quanto ao valor mínimo da resistência à compressão, tendo em vista que essa especificação busca atender a um critério somente empírico que não encontra nenhuma fundamentação matemática. Observa-se, a importância da existência de análises mais mecanísticas para aceitação dos blocos em função do carregamento real que irá atuar sobre ele, como por exemplo: veículos ou pedestres.

De um modo geral, a pesquisa aqui apresentada buscou substituir a maior quantidade possível de cinza pesada na fabricação de BCPI. Entretanto, à luz dos resultados aqui apresentados, o melhor traço alternativo é aquele que testou $10 \%$ de cinzas na sua composição.

Nos itens que se seguem serão resumidos os resultados das substituições dos diversos teores de cinzas realizadas e seus principais benefícios e limitações.

\subsection{Quanto aos Resultados dos Ensaios de Caracterização dos Materiais}

Tendo em vista os resultados dos ensaios de caracterização da amostra integral de cinza, optou-se pela substituição da fração miúda no concreto, pois essa atendeu aos requisitos normativos. 
A cinza pesada in natura apresentou um equilíbrio na composição granulométrica, ou seja, possui frações, graúdas, miúdas e parcela de material fino em sua composição. Por essa característica, houve possibilidade de substituição em qualquer das frações.

A resistência ao desgaste à abrasão "Los Angeles" do AGCP segundo a ABNT 7211:2009 não teve um bom resultado, pois demonstrou um comportamento "frágil" e "quebradiço" de 79\% da amostra, valor esse considerado elevado. Porém, não implica afirmar que seu uso seja inviabilizado para outros fins na pavimentação. Mesmo assim, para esta pesquisa optou-se por não utilizar a fração graúda da cinza.

Os agregados naturais caracterizaram-se potencialmente inócuos no ensaio de reatividade álcali-agregado. A cinza pesada apresentou valor de $0,48 \%$ e ultrapassou o limite permitido $(0,19 \%$ aos 30 dias $)$ indicando que a cinza pesada é potencialmente reativa conforme a ABNT NBR 15577-4:2009.

Os ensaios ambientais (solubilização e lixiviação) resultaram na classificação dos AGCP e AMCP como resíduos classe II A - não perigosos e não inertes que segundo essa classificação pode ser utilizado para outros fins. Para os demais ensaios de caracterização, os AGCP e AMCP tiveram resultados satisfatórios para uso como agregado no concreto.

\subsection{Quanto aos Resultados dos Ensaios Mecânicos nos Blocos Intertravados}

No resultado do concreto no estado fresco, fabricado para os BCPI, apresentaramse resultados práticos do consistômetro "VeBe" modificado realizado nos seis traços, classificado como concreto extremamente seco, porém não houve nenhuma modificação que identifica-se algum tipo de limitação a realização do ensaio causado pela modificação do mesmo.

No estado endurecido realizaram-se ensaios de inspeção visual e avaliação dimensional e todos os traços dos BCPI foram considerados adequados com relação à ABNT NBR 9781:2013.

Ainda no estado endurecido no que diz respeito à absorção de água dos blocos aos 28 dias de idade, apenas o T10 poderia ser aceito, considerando apenas a média dos valores de absorção. No entanto, se considerar as absorções individuais dos blocos, todos os traços seriam aprovados, exceto o T40 que não apresentou absorção $>7 \%$.

Para o caso do ensaio de resistência à compressão simples, nas idades de 7 e 28 dias, todos os seis traços fabricados não atenderam às exigências da ABNT NBR 9781:2013. 
Quanto à resistência à abrasão os blocos obtiveram resultados satisfatórios, pois apresentaram desgastes inferiores ao preconizado na ABNT NBR 9781:2013.

Por fim, quanto aos ensaios ambientais (solubilização e lixiviação) a classificação das amostras dos BCPI foi como resíduos classe II A - não perigosos e não inertes. Sendo assim, podem ser construídos pavimentos intertravados com blocos fabricados com cinza pesada.

\subsection{Sugestões para novas Pesquisas}

- Desenvolver um estudo de dosagem de concreto seco com CPIN.

- Fabricar novos traços, utilizando outros métodos de dosagem.

- Testar outros traços de referência de concreto, com cinza e com agregados naturais.

- Investigar e discutir melhor os parâmetros adotados como mínimos em norma como, por exemplo, a resistência à compressão simples.

- Analisar parâmetros mecanísticos para entender melhor o projeto de pavimentos com blocos intertravados.

- Construir e monitorar trechos experimentais com BCPI.

- Testar outros tipos de agregados naturais com a cinza.

- Fabricar o concreto para os BCPI com substituição de cinza pesada, utilizando outros tipos de cimento, como o CPII.

\subsection{Considerações Finais}

Com a preocupação com a geração de resíduos, desenvolveu-se uma metodologia visando aplicar um maior percentual de cinza pesada em BCPI. Os resultados apresentados no presente trabalho indicaram possibilidade do uso das cinzas na composição dos pavimentos intertravados.

A utilização das cinzas pesadas em BCPI pode apresentar vantagens tanto em relação aos aspectos técnico-econômicos, quanto em relação às questões ambientais e estéticas. O aproveitamento desse resíduo contribui para o desenvolvimento sustentável do local onde esteja localizado, reduzindo a extração de matérias-primas não-renováveis, otimizando o uso dos aterros e contribuindo para o não crescimento desgovernado desses.

No entanto, ainda que os BCPI fabricados nesta pesquisa não atenderam $100 \%$ às exigências da ABNT NBR 9781:2013 (para tráfego de veículos leves e veículos comerciais de 
linha, de veículos especiais e solicitações capazes de produzir efeitos de abrasão acentuados), ainda há a possibilidade de serem utilizados em calçadas, passeio público, urbanização, redutor de velocidade ou em locais que não demandem elevada solicitação do pavimento. 


\section{REFERÊNCIAS}

AASHTO. Guide for design of pavement structures. American Association of State Highway and Transportation Officials. Washington: D.C, 1993.

ALENCAR, R. dos S. A. Dosagem do concreto auto-adensável: produção de préfabricados. 2008. 165 p.Dissertação (Mestrado). Escola Politécnica, Universidade de São Paulo, São Paulo, 2008.

AL ROUSAN, T. M. Characterization of aggregate shape properties using a computer automated system. 2004. 211f. Tese (Doutorado em Engenharia Civil) - College Station, Texas, 2004.

AMERICAN CONCRETE INSTITUTE - ACI 211.3 - Prática recomendada para a seleção e proporções de concreto No - Slump, 1975.

AMERICAN SOCIETY FOR TESTING AND MATERIALS - ASTM, C1170 - Métodos de teste padrão para determinação da consistência e densidade de concreto compactado com rolo usando mesa vibratória, 1991.

AMERICAN SOCIETY FOR TESTING AND MATERIALS - ASTM, C936/C936M - 18. Especificação padrão para unidades de pavimentação de intertravamento de concreto sólido, 2018.

ARY JUNIOR, I. J. Pavimento intertravado como ferramenta de moderação do tráfego nos centros comerciais de travessias urbanas - estudo de caso Guaiúba, CE. 2007. 208f. Dissertação (Mestrado em Engenharia de Transportes) - Centro de Tecnologia, Universidade Federal do Ceará, Fortaleza, 2007.

ASSOCIAÇÃO BRASILEIRA DE CIMENTO PORTLAND - ABCP. Guia básico de utilização do cimento Portland. 7. ed. São Paulo, 2002.

ASSOCIAÇÃO BRASILEIRA DE CIMENTO PORTLAND ABCP. Manual de Pavimento Intertravado: passeio público. São Paulo, 2010.

ASSOCIAÇÃO BRASILEIRA DE NORMAS TÉCNICAS. ABNT NBR 10004: resíduos sólidos - classificação. 2 ed. Rio de Janeiro: ABNT, 2004.

ABNT NBR 10.005: procedimento para obtenção de extrato lixiviado de resíduos sólidos. Rio de Janeiro: ABNT, 2004b.

ABNT NBR 10.006: procedimento para obtenção de extrato solubilizado de resíduos sólidos. 2. ed. Rio de Janeiro: ABNT, 2004.

$2004 d$.

ABNT NBR 10.007: amostragem de resíduos sólidos. 2. ed. Rio de Janeiro: ABNT,

ABNT NBR 10157: aterro de resíduos sólidos perigosos - critério para projeto, construção e operação. Rio de Janeiro: ABNT, 1987. 
ABNT NBR 11170: serviços de pavimentação - terminologia. Rio de Janeiro: ABNT, 1990.

ABNT NBR 11768: aditivos químicos para concreto de cimento Portland requisitos. Rio de Janeiro: ABNT, 2011.

ABNT NBR 12042: materiais inorgânicos - determinação do desgaste por abrasão. 2. ed. Rio de Janeiro: ABNT, 1992.

ABNT NBR 15112: resíduos da construção civil e resíduos volumosos - áreas de transbordo e triagem - diretrizes para projeto, implantação e operação. Rio de Janeiro: ABNT, 2004.

ABNT NBR 15900-1: água para amassamento do concreto. Parte 1: Requisitos. Rio de Janeiro: ABNT, 2009.

ABNT NBR 16697: cimento Portland - requisitos. Rio de Janeiro: ABNT, 2018.

ABNT NBR 248: agregados - determinação da composição granulométrica. Rio de Janeiro: ABNT, 2003.

ABNT NBR 7211: agregados para concreto - especificação. 3. ed. Rio de Janeiro: ABNT, 2009.

ABNT NBR 9781: peças de concreto para pavimentação - especificação e métodos de ensaio. 2. ed. Rio de Janeiro: ABNT, 2013.

ABNT NBR 9917: agregados para concreto — determinação de sais, cloretos e sulfatos solúveis. Rio de Janeiro: ABNT, 2009.

ABNT NBR 15116: agregados reciclados de resíduos sólidos da construção civil utilização em pavimentação e preparo de concreto sem função estrutural - requisitos. Rio de Janeiro: ABNT, 2004.

ABNT NBR NM 30: agregados miúdo - determinação da absorção de água. Rio de Janeiro: ABNT, 2001.

ABNT NBR NM 46: agregados - determinação do material fino que passa através da peneira $75 \mu \mathrm{m}$, por lavagem. Rio de Janeiro: ABNT, 2003.

ABNT NBR NM 51: agregado graúdo - ensaio de abrasão "Los Ángeles". Rio de Janeiro: ABNT, 2001.

ABNT NBR NM 52: agregado miúdo - determinação de massa especifica e massa especifica aparente. Rio de Janeiro: ABNT, 2003.

ABNT NBR NM 53: agregado graúdo - determinação de massa específica, massa específica aparente e absorção de água. Rio de Janeiro: ABNT, 2009. 
ABNT NBR NM ISO 3310-1: peneiras de ensaio - requisitos técnicos e verificação

Parte 1: Peneiras de ensaio com tela de tecido metálico. Rio de Janeiro: ABNT, 2010.

BARROS, K. S. Estudo de Cinzas Volantes de uma Termelétrica da Região Metropolitana de Fortaleza-CE para Aplicação em Camadas Granulares de Pavimentos. 2015. 143f. Dissertação (Mestrado em Engenharia Civil) - Programa de PósGraduação em Engenharia de Transportes, Universidade Federal do Ceará, Fortaleza, 2015.

BESSA, I. S. Avaliação do processamento digital de imagens como ferramenta para caracterização de agregados e misturas asfálticas. 2012. 153f. Dissertação (Mestrado em Engenharia de Transportes) -Centro de Tecnologia, Universidade Federal do Ceará, Fortaleza, 2012.

BITENCOURT, R. G. S., ARNS, P. Dimensionamento de pavimento flexível intertravado para tráfego muito pesado. Santa Catarina, n. 1, p 1-21, 2014. Disponível em: < http://repositorio.unesc.net/bitstream/1/2980/1/Ramon\%20G.\%20S.\%20Bitencourt.pdf>. Acesso em: 10 ago. 2018.

BITTENCOURT, S. F. Avaliação da resistência à compressão de pavers produzidos com agregados de resíduos de construção e areia de fundição. 2012, 125f. Dissertação (Mestrado em Tecnologia e Inovação) - Faculdade de Tecnologia, de Campinas, Universidade Estadual de Campinas, Limeira, 2012.

BRASIL. Conselho Nacional de Meio Ambiente (CONAMA). Resolução CONAMA nº 006, de 15 de junho de 1988. Diário Oficial da União, Brasília, DF: Imprensa Oficial, 1988.

Resolução CONAMA n 313, de 29 de outubro de 2002. Dispõe sobre o inventário nacional de resíduos sólidos industriais. Diário Oficial da União, Brasília, DF: Imprensa Oficial, 2002.

Resolução CONAMA no 358, de 29 de abril de 2005. Dispõe sobre o tratamento e a disposição final dos resíduos dos serviços de saúde e dá outras providências. Diário Oficial da União; Poder Executivo, 2005.

. Resolução CONAMA n ${ }^{\circ}$ 26.604, de 16 de maio de 2002. Trata sobre a gestão dos resíduos sólidos ser de responsabilidade de toda a sociedade. Diário Oficial do Estado, Fortaleza, CE, 2002.

Resolução CONAMA n ${ }^{\circ}$ 307, de 05 de junho de 2002. Estabelece diretrizes, critérios e procedimentos para a gestão dos resíduos sólidos da construção civil. Diário Oficial da União, Brasília, DF: Imprensa Oficial, 2002.

Decreto $N^{\text {o }} 7.404$ de 23 de dezembro de 2010. Regulamenta a Lei no 12.305 de 2 de agosto de 2010, que institui a Política Nacional de Resíduos Sólidos, cria o Comitê Interministerial da Política Nacional de Resíduos Sólidos e o Comitê Orientador para a Implantação dos Sistemas de Logística Reversa, e dá outras providências. Presidência da República. Brasília, 2010. Disponível em: < http://www.planalto.gov.br/ccivil_03/_Ato20072010/2010/Decreto/D7404.htm>. Acesso em: 10 maio 2018. 
BRASIL. Ministério dos Transportes. Departamento Nacional de Estradas de Rodagem DNER - ME 084/95. Agregado miúdo - determinação de densidade real. Rio de Janeiro, 1995.

BRASIL. Lei n ${ }^{\circ} 12.305$, de 2 de agosto de 2010. Institui a Política Nacional de Resíduos Sólidos; altera a Lei $\mathrm{n}^{\circ}$ 9.605, de 12 de fevereiro de 1998; e dá outras providências. Brasília, 2010.Disponível em: <http://www.planalto.gov.br/ ccivil_03/_ato20072010/2010/lei/l12305.htm>. Acesso em: 10 mar. 2018.

CARVALHO, M. D. Pavimentação com peças pré-moldadas de concreto. São Paulo: Associação Brasileira de Cimento Portland - Estudo Técnico, 1998. Disponível em:<http://ptdocz.com/doc/1295180/et-27---abcp>. Acesso em: 07 ago. 2018.

CLEMENTINO, F. de C.; BARROS, G. R.; SANTOS, P. G. D. Processo produtivo em uma indústria de artefatos de concreto. 2014. 100f. Monografia (Curso de Engenharia Civil) Universidade Federal de Goiás, Goiânia, 2013.

COSTA, A. V., GUMIERI, A. G., BRANDÃO, P. R. G. Piso intertravado produzido com rejeito de sinter feed. Revista IBRACON de Estrutura e Materiais, Belo Horizonte, v. 7, n. 2, p. 228-259, abr. 2014. Disponível em: < http://www.scielo.br/pdf/riem/v7n2/v7n2a04.pdf>. Acesso em: 10 abr. 2018.

COSTA, C. E. Incorporação de rejeitos na indústria cerâmica. Qualidade na construção. SindusCon, São Paulo, n. 12, ano II, p. 44-46, 1998.

CRUZ, L. O. M. Pavimento intertravado de concreto: estudo dos elementos e métodos de dimensionamento. 2003. 281f. Dissertação (Mestrado) - Universidade Federal do Rio de Janeiro-UFRJ, Rio de Janeiro, 2003.

DEPARTAMENTO NACIONAL DE INFRAESTRUTURA DE TRANSPORTES (DNIT). Diretoria de Planejamento e Pesquisa. Coordenação do Instituo de Pesquisas Rodoviárias (IPR). Manual de Pavimentos Rígidos. 2. ed. Rio de Janeiro: IPR. Publ., 2004.

DNIT 138/2010 - Especificação do serviço: pavimentação - Reforço do subleito. Rio de Janeiro: IPR. 2010.

DOWSON, A. Mix design for concrete block paving. Procedures 1st International Conference on CBP. 1980. p. 121-127.

EMPRESA T \& A - Blocos e Pisos. Manual Técnico de Blocos de Concreto, 2005. Disponível em: <http://www.tea.com.br/wpcontent/uploads/2011/05/Manual_Tecnico_Blocos_2010.pdf>. Acesso em: 07 ago. 2018.

EMPRESA T \& A - Blocos e Pisos. Manual Técnico de Piso Intertravado de Concreto. 2004. Fortaleza - CE. Disponível em: <http://www.tea.com.br/wp-content/uploads/2011/05 /Manual_Tecnico_Pisos_2010.pdf>. Acesso em: 07 ago. 2018.

ET-27. Pavimentação com peças pré-moldadas de concreto. 4. ed. São Paulo - SP, 1999. 
FARIA, R. Pavimento intertravado: desgaste físico e intensidade do tráfego sobre o piso definem o tipo de bloco que deve ser utilizado na pavimentação. Como construir na prática Equipe de Obra, 2011. Disponível em:< http://equipedeobra17.pini.com.br/construcaoreforma/40/pavimento-intertravado-236319-1.aspx>. Acesso em: 25 ago. 2018.

FERNANDES, I. D. Blocos e Pavers: produção e controle de qualidade. Ribeirão Preto, SP: Treino Assessoria e Treinamentos Empresariais Ltda, 2008.

FERREIRA, F. de A. Análise do dimensionamento de pavimentos asfálticos utilizando o programa SISPAVBR. 2013. Tese (Doutorado). Universidade Federal do Rio de Janeiro, Rio de Janeiro, 2013.

FIORITI, C. F. Pavimentos intertravados de concreto utilizando resíduos de pneus como material alternativo. 2007. 202f. Tese (Doutorado). Escola de Engenharia da Universidade de São Paulo, São Carlos, 2007.

FIORITI, C. F. INO, A.; AKASAKI, J. L. Análise experimental de blocos intertravados de concreto com adição de resíduos do processo de recauchutagem de pneus. Acta Scientiarum: Technology (Online), v. 32, p. 237-244, 2010.

GODINHO, D. P. Pavimento Intertravado: uma reflexão sob a ótica da durabilidade e sustentabilidade. 2009. 158 f. Dissertação (Mestrado) - Curso de Ambiente Construído e Patrimônio Sustentável, Escola de Arquitetura, Universidade Federal de Minas Gerais, Belo Horizonte, 2009.

GONÇALVES, F. J. P. Estudo experimental do desempenho de pavimentos flexíveis a partir de instrumentação e ensaios acelerados. 2002. 467f. Tese (Doutorado), Programa de Pós-Graduação em Engenharia Civil, Universidade Federal do Rio Grande do Sul, Porto Alegre, 2002.

GREGORIO, L. T. D. Orientações para fabricação de blocos de concreto e pisos intertravados. PROJETO SHS Solução Habitacional Simples/ Simple Housing Solution. Rio de Janeiro / Cachoeira Paulista, 2012.

HALLACK, A. Dimensionamento de pavimentos com revestimento de peças prémoldadas de concreto para áreas portuárias e industriais. 1998. 216f. Dissertação (Mestrado em Engenharia Civil), Escola Politécnica, Universidade de São Paulo, São Paulo,1998.

HEIN, D. K.; TYSON, S. S.; SMITH, D. R. Concrete Turns Green, Figuratively Speaking. U.S. Departament of Transportation Federal Highway Administration. Federal Highway Administration Research and Technology Coordinating, Developing and Delivering Higway Transportation Innovations. Unites State: Federal Highway Administration, v. 79, n. 3, nov/dez. 2015. Disponível em: < https://www.fhwa.dot.gov/publications/publicroads/15novdec/03.cfm>. Acesso em: 06 ago. 2018.

HELENE, P.; TERZIAN, P. Manual de dosagem e controle do concreto. São Paulo: PINI/SENAI, 1992, 313p. 
HELENE, P. Dosagem do concreto de cimento Portland. In: ISAIA, G. C. Editor. In:

Concreto: Ensino, pesquisa e realizações. São Paulo: Ed. IBRACON, v. 1. p. 75-107, 2005.

HÜSKEN, G.; BROUWERS, H. J. H. A new mix design concept for earth-moist concrete: a theoretical and experimental study. Cement and Concrete Research, Netherlands, v. 38, n. 10, p. 1246-1259, 2008. Disponível em:

<https://josbrouwers.bwk.tue.nl/publications/Journal51.pdf>. Acesso em: 12 ago. 2018.

HUURMAN, M.; HOUBEN, L. J. M.; KOK, A. W. M. Development of a threedimensional finite element model for concrete block pavements. In: Proceedings Fourth International Conference on Concrete Block Paving. Delft University of Technology, Delft, The Netherlands, p. 89-98, 1998. Disponível em: < http://www.sept.org/techpapers/10.pdf>. Acesso em: 12 ago. 2018.

IBIAPINA, D. S., Proposição de um sistema de classificação das propriedades de forma de agregados caracterizados com o uso do processamento digital de imagens para a seleção de materiais brasileiros. 2018. 176f. Tese (Doutorado), Programa de Pós-Graduação em Engenharia de Transporte - PETRAN, Universidade Federal do Ceará - UFC, Fortaleza CE, 2018.

ILAN IHAI, I.; YAACOBI, S.; SUSANA BROWN-COHEN, S. Design and construction of concrete block pavements for heavy duty railway freight terminal. 8th International.

Conference on Concrete Block Paving, nov., p. 6-8, 2006, San Francisco, California USA. Disponível em: <http://www.sept.org/techpapers/1360.pdf〉. Acesso em: 12 ago. 2018.

INSTITUTO BRASILEIRO DE IMPERMEABILIZAÇÃO (IBI). Manual de Utilização de Aditivos para Concreto Dosado em Central. [20?]. Disponível em: 〈www.ibisp.org.br〉. Acesso em: 03 mai. 2018.

INSTITUTO DE PESQUISA ECONÔMICA APLICADAS (IPEA). Diagnóstico dos Resíduos Sólidos Industriais. Relatório de Pesquisa. Governo Federal. Secretaria de Assuntos Estratégicos da Presidência da República. 2012. Disponível em:

<http://ipea.gov.br/agencia/images/stories/PDFs/relatoriopesquisa/120927_relatorio_residuos _solidos_industriais.pdf>. Acesso em: 03 ago. 2018.

INSTITUTO DE PESQUISAS RODOVIÁRIAS - IPR. Pesquisa de Concreto Rolado. ME: Rio de Janeiro, [20?].

INTERLOCKING CONCRETE PAVEMENT INSTITUTE (ICPI). Glossary of terms Used in the Production, Design, Construction and Testing of Interlocking Concrete Pavement, Tech Spec. n. 1. Washington, USA, 2002.

Structural Design of Interlocking Concrete Pavement for Roads and Parking Lots. Tech Spec. n. 4. Washington, USA, 2006.

Selection of Bedding Sands for Interlocking Concrete Pavements in Vehicular Applications, Tech Spec. n. 17. Washington, USA, 2007. 
IP-06/2004. Dimensionamento de pavimentos com blocos intertravados de concreto. Disponível em: <https://docplayer.com.br/10221825-Ip-06-instrucao-para-dimensionamentode-pavimentos-com-blocos-intertravados-de-concreto.html>. Acesso em: 07 abr. 2018.

JUVAS, K. Very dry precasting concrete. Special Concretes: Workability and Mixing. Proceeding of the International RILEM Workshop. London. p. 153-158, 1993.

KOKUBU, K.; CABRERA, J. G.; UENO, A. Compaction Proprieties of Roller Compacted Concrete. Departament of civil Engineering, Tokio Metropolitan University, Tokio, Japan and Civil Engineering Materials Units, Department of civil Engineering University of Leeds, 1995.

KOSMATKA, S. H., KERKHOFF, B., PANARESE, W. C. Design and control of concrete mixtures. Portland Cement Association. USA: Skokie, 2002.

LEANDRO, R. P. Estudo laboratorial acerca da possibilidade de aproveitamento da cinza pesada de termoelétrica em bases e sub-bases de pavimentos flexíveis. 2005. Dissertação (Mestrado em Transportes) - Escola de Engenharia de São Carlos, Universidade de São Paulo, São Carlos, 2005.

LEANDRO, R. P. Utilização das cinzas pesadas provenientes da queima de carvão mineral em cliques de contenção: aspectos técnicos e ambientais. 2002. 143p. TCC. Universidade do Sul de Santa Catarina (USSC), Tubarão, 2002.

MADRID, G. G. Standards and specifications for concrete paving blocks in LatinAmerican countries. In: International Concrete Block Paving Conference. Auckland, New Zealand, 1992.

MARCHIONI, M. L. Desenvolvimento de técnicas para caracterização de concreto seco para peças de concreto para pavimentação intertravada. 2012. Dissertação (Mestrado) Departamento de Engenharia de Construção Civil, Escola Politécnica da Universidade de São Paulo, São Paulo, 2012.

MARINONI, N.; VOLTOLINI, M.; MANCINI, L.; CELLA, F. Influence of aggregate mineralogy on alkali-silica reaction studied by X-ray powder diffraction and imaging techniques. Journal of Materials Science, v. 47, n. 6, p. 2845-2855, 2012.

MEHTA, P. K.; MONTEIRO, P. J. M.; CARMONA F. A. Concreto: estrutura, propriedades e materiais. São Paulo: PINI, 1994.

MOTA, M. H. A. Concreto seco com incorporação de cinzas de madeira de Algaroba (prosopis juliflora) moldado sob pressão. 2014. Dissertação (Mestrado). Programa de Pósgraduação em Engenharia Civil e Ambiental (PPGECAM), UFPE, Caruaru, 2014.

MOTTA, R. dos S. Estudo laboratorial de agregado reciclado de resíduo sólido da construção civil para aplicação em pavimentação de baixo volume de tráfego. 2005. Dissertação (Mestrado) - Departamento de Engenharia de Transportes, Escola Politécnica da Universidade de São Paulo, 2005. 
MULLER, R. M. Avaliação de transmissão de esforços em pavimentos intertravados de blocos de concreto. 2005. Dissertação (Mestrado em Ciências em Engenharia Civil), Programa de Pós-Graduação em Engenharia da Universidade Federal do Rio de Janeiro UFRJ / COPPE. Rio de Janeiro, 2005.

NACIMENTO, P. N. Política nacional de resíduos sólidos - reflexões acerca do novo marco regulatório nacional. Revista Brasileira de Ciências Ambientais. Número 15, p. 10-19, mar/ 2010. ISSN Impresso 1808-4524 / ISSN Eletrônico: 2176-9478. Disponível em: <http://www.abes-dn.org.br/publicacoes/rbciamb/PDFs/15-04_RBCIAMB-N15-Mar-2010Materia02_artigos225.pdf>. Acesso em: 04 set.2018.

NASCIMENTO, J. C. F. Comportamento mecânico de resíduos sólidos urbanos. 2007. Dissertação (Mestrado em Geotecnia) - Escola de Engenharia de São Carlos, USP, São Carlos, 2007.

OLIVEIRA, A. L. Contribuição para a dosagem e produção de peças de concreto para pavimentação. 2004. Tese (Doutorado em Engenharia Civil) - Programa de Pós-Graduação em Engenharia Civil, Universidade Federal de Santa Catarina, Florianópolis, 2004.

PAVEMENTS. First edition and reprinted. New York and London: Elsevier, 1991.

Pavimento Intertravado alia durabilidade e estética, 2010. Disponível em: $<$ http://www.abcp.org.br/cms/imprensa/banco-de-pautas/pavimento-intertravado-aliadurabilidade-e-estetica/>. Acesso em: 21 abr. 2012.

PEC MAQ \& PC FORMAS. A sua fábrica de fôrmas. Site:

$<$ https://www.pecformas.com.br/formas-para-concreto-pisos-pavers-autotravantes.php>. Acesso em: 03 jul. 2018.

PETTERMANN, R. Avaliação do desempenho de blocos de concreto para pavimentação com metacaulim e sílica ativa. 2006. Monografia (Especialização em Engenharia Civil) Programa Pós-Graduação em Engenharia Civil, Universidade Federal do Rio Grande do Sul, Porto Alegre, 2006.

PINI. Edição 40, 2005. Disponível em: <http://equipedeobra.pini.com.br/construcaoreforma/40/pavimento-intertravado-236319-1.aspx >. Acesso em: 05 maio 2018.

PIROLA, F. C. Contribuição para o estudo de concreto seco utilizado na fabricação de peças de concreto para pavimentação de 50mpa. 2011. Dissertação (Mestrado) Universidade Federal de Santa Catarina, Departamento de Engenharia Civil, Florianópolis, 2011.

POKHARKAR, D.; SANCHIT, S.; ISLAM, M.; WADGE. Y. A Review Paper on Design of Pavement Block Students, Department of Civil Engineering, Jaihind Polytechnic Kuran, India. International Journal Of Engineering Sciences \& Management. ISSN 2277 - 5528. Impact Factor- 4.015. Índia, 2017. 
POON, C.S., S.C. KOU, L. L. Use of Recycled Aggregates in Molded Concrete Bricks and Blocks. Construction and Building Materials, Science Direct, China, v. 16, 5. ed., p. 281-289, 2002. Disponível em:

<https://www.sciencedirect.com/science/article/abs/pii/S0950061802000193>. Acesso em:

RIBEIRO, A. G. Variância e desvio padrão. Disponível em:

$<$ https://mundoeducacao.bol.uol.com.br/matematica/variancia-desvio-padrao.htm>. Acesso em: 03 set. 2018.

RODRIGUES, P. P. F. Estágio atual da pavimentação intertravada no Brasil. In: $4^{\circ}$ Seminário sobre normalização de cimento, concreto e agregados. São Paulo, IBRACON, 1986.

RODRIGUES, P. P. F. Parâmetros de dosagem do concreto. São Paulo: ABCP, 1984.

RODRIGUES, P. P. F. Recomendações para a fabricação de peças pré-moldadas de concreto para pavimentação. In: Reunião anual, São Paulo: IBRACON, 27 a 31 agosto, 1984.

RUSCH, H. Hormigon armado y hormigon pretensado. Barcelona: Comp. Ed. Continental s/a, 1975.

SABEDOT, S.; SUNDSTRON, M. G.; BOER, S. C.; SAMPAIO, C.H.; DIAS, R. G. O; e RAMOS, C.G. Caracterização e aproveitamento de cinzas da combustão de carvão mineral geradas em usinas termelétricas. In: Anais do III Congresso de Carvão Mineral. UFRGS, 2011.

SANTOS, C. R. Estudo da utilização de rejeitos de carvão na fabricação de blocos de concreto para pavimentação em substituição ao agregado miúdo natural. 2012. Dissertação (Mestrado) - Programa de Pós-Graduação em Engenharia de Minas, Metalúrgica e de Materiais, Universidade Federal do Rio Grande do Sul, Porto Alegre, 2012.

SANTOS, A. V., BORJA, E. V. Avaliação das propriedades mecânicas de blocos intertravados com resíduo de pneu reciclado. Holos, Ano 23, Vol. 3, 2007. Disponível em: <http://www2.ifrn.edu.br/ojs/index.php/HOLOS/article/viewFile/128/116>. Acesso em: 03 set. 2018

SENÇO, Wlastermiler. Manual de Técnicas de Pavimentação. São Paulo: Editora PINI, 1997.

SHACKEL, B. Design and construction of interlocking concrete block pavements. New York; London; Elsevier Applied Science, 1990.

SILVA, F. M.; VAZ, V. V; BARBOSA, L. A. G., LINTZ, R. C. C. Avaliação da resistência mecânica de pisos intertravados de concreto sustentáveis (PICS). Matéria (Rio de Janeiro) [online]. 2017, vol.22, n.1, e11778. Epub Apr 10, 2017.

SILVA, M. N. P. Média Aritmética. Notas de aula. Disponível em: < https://mundoeducacao.bol.uol.com.br/matematica/media-aritmetica.htm >. Acesso em: 03 set. 2018. 
SILVEIRA, W. H. Estudo da trabalhabilidade de concreto para blocos de vedação com consistômetro de Vebe. 2015. Trabalho de Conclusão de Curso (Bacharelado em Engenharia Civil) - Universidade Tecnológica Federal do Paraná, Campo Mourão, 2015.

SMITH, D. R. Grand Entrances. Interlocking Concrete Magazine, v.10, number 2, p.4. 2003.

SMITH, D. R. The Institutionalization of Concrete Block Pavements in North America. Fourth International Conference on Concrete Block Paving. p. 355-360, 1992.

TANGO, C. E. de S. Fundamentos de dosagem de concretos para blocos estruturais. 5th International Seminar on Structural Masonry for Developing Countries, 5. Florianópolis, Brasil, Anais..., Florianópolis, 1994.

TOCCHETTO, M. R. L. Gerenciamento de resíduos sólidos industriais. 2009. Curso de Especialização em Tratamento e Disposição Final de Resíduos Sólidos e Líquidos. Universidade Federal de Goiás, 2009.

VASCONCELOS, S. D. Avaliação da Heterogeneidade de Cinzas de Carvão Mineral Advindas da Termelétrica Energia Pecém e sua Aplicação em Camadas Granulares de Pavimentos. 2016. Monografia (Curso de Engenharia Civil) - Universidade Federal do Ceará, Fortaleza, 2016.

WIEBBELLING, P. O. G. Pavimento com blocos intertravados de concreto: estudo de caso na UNIVATES. 2015. Monografia (Curso de Engenharia Civil) - Universidade do Vale do Taquari, Lajeado - RS, 2015. 


\section{APÊNDICE A - PROCESSO DE FABRICAÇÃO DO CONCRETO PARA OS BLOCOS}

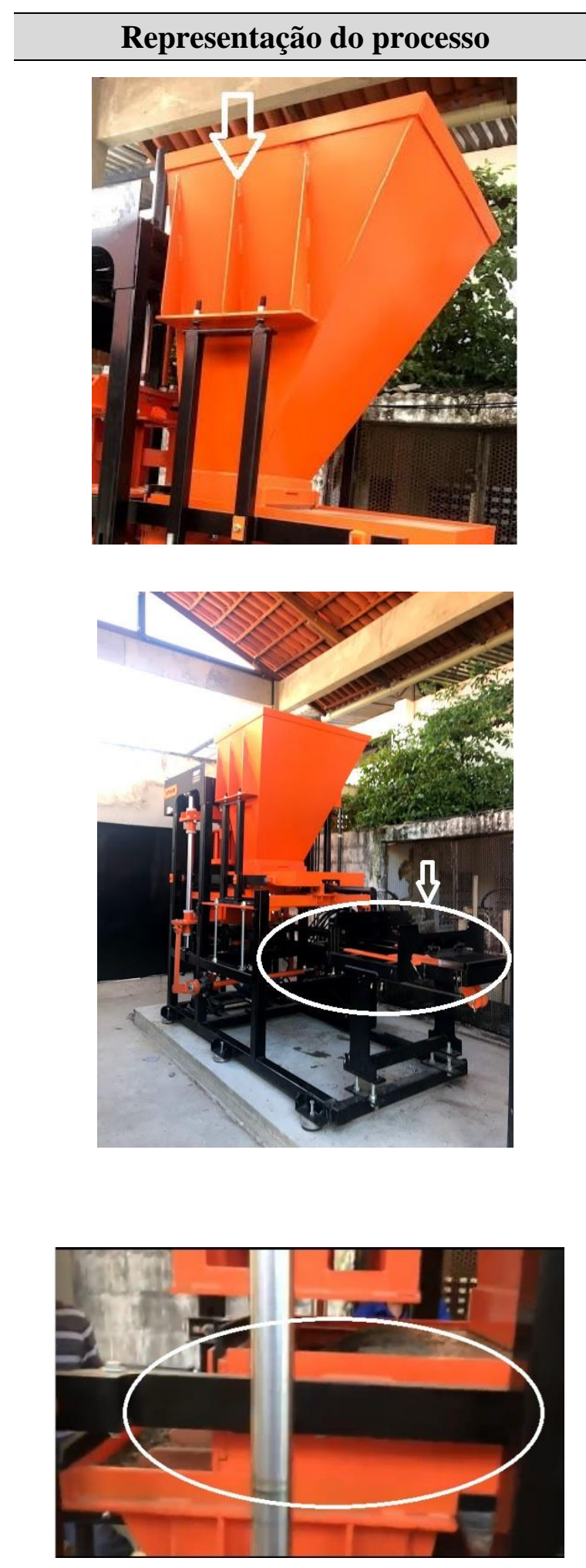

- Transportar o concreto manualmente até a vibroprensa;

- Lançar manualmente no silo, sobre uma plataforma de aço galvanizado (indicado na imagem ao lado);

- Acionar o alimentador de tábuas, localizado na área indicada da imagem, na parte atrás da máquina.

- O alimentador funciona com movimentos na horizontal, onde, empurra para frente as tábuas até o alinhamento da forma.

- Acionar o carro alimentador de concreto que fica em baixo do silo. Essa alimentação é por gravidade;

- A gaveta funciona com movimentos do carro na horizontal, nos dois sentidos;

- Quando o carro se movimenta no sentido da frente ele alimenta a forma, quando no sentido contrário regulariza o concreto lançado; 

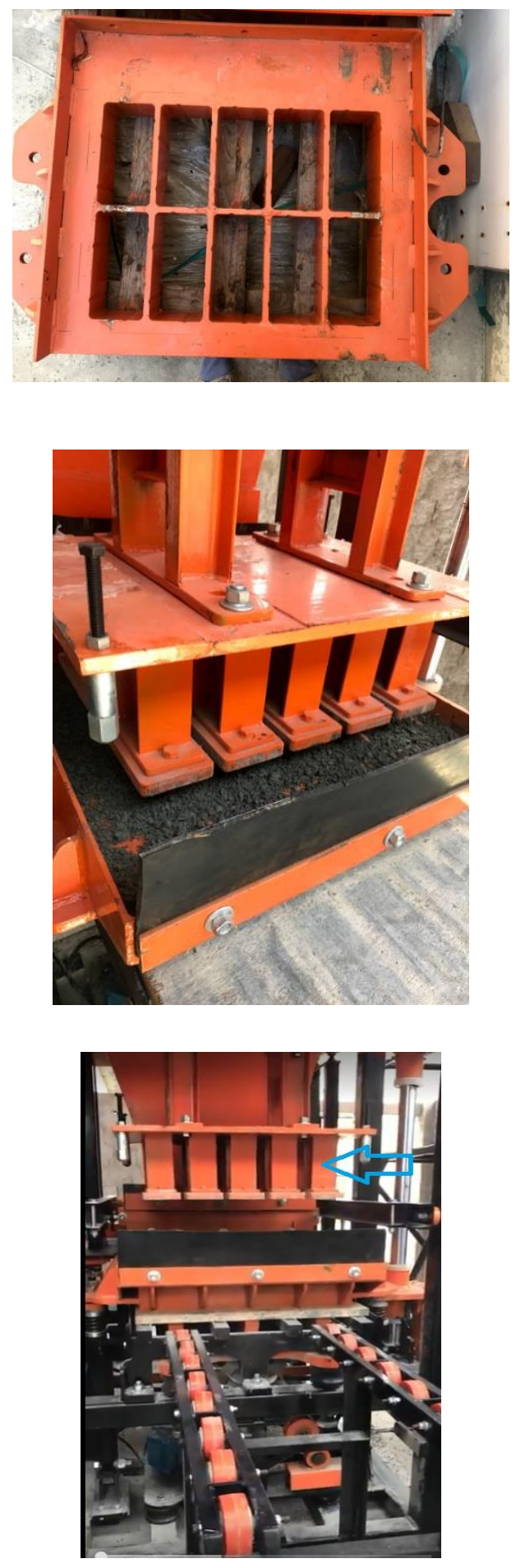

- A forma é parte componente da máquina, sendo disponibilizadas vários tipos de formato;

- Para alimentar a forma passa-se o carro espalhando o concreto, com a máquina em funcionamento, vibrando;

- A forma deve estar totalmente assentada na tabua nivelada;

- A forma de ser preenchida com concreto até o nivelamento da forma, conforme imagem;

- Acionar o castelo, parte da máquina que encaixa na forma para compressão do concreto;

- Após a forma está totalmente preenchida, movimentá-lo no sentido vertical, para baixo;

- Aproximar o castelo no concreto ao mesmo tempo que a máquina está em funcionamento; 

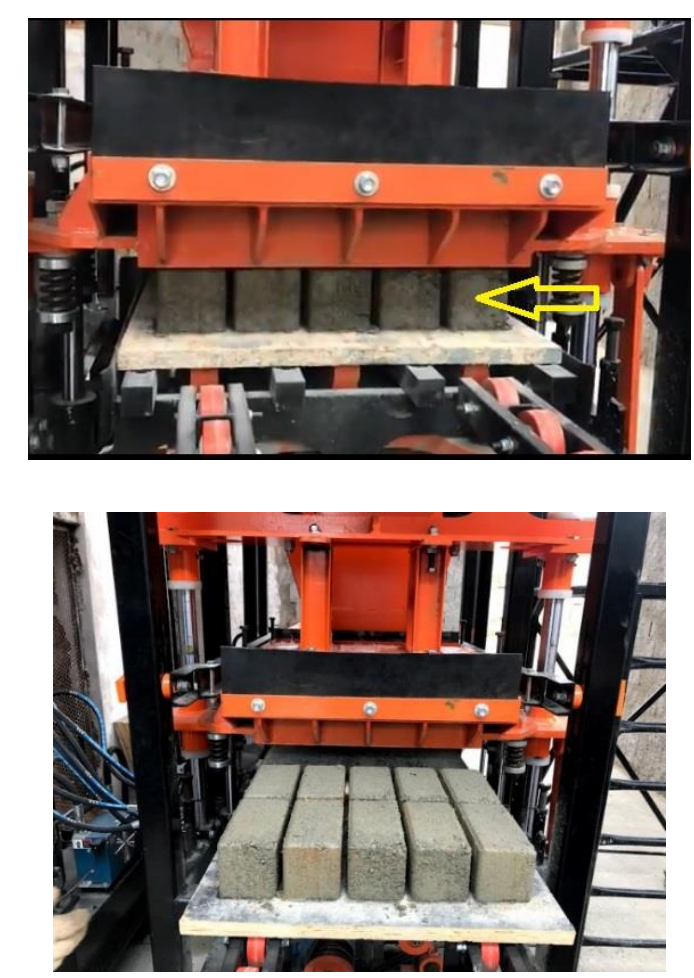

Fonte: Autora (2018).
- Depois de prensado e vibrado ao mesmo tempo o concreto, tem-se o bloco moldado;

- Levanta-se a forma e o castelo devagar até soltarem os blocos por completo;

- Visualizado a saída dos blocos, acionar o carro das tábuas, para empurrar a próxima tábua e continuar o processo até que não haja mais concreto no silo.

- Transportar as tábuas com os blocos para um local onde possa ser coberto por uma lona no período de 24 horas; 